This PDF is a selection from a published volume from the National Bureau of Economic Research

Volume Title: A History of Corporate Governance around the World: Family Business Groups to Professional Managers

Volume Author/Editor: Randall K. Morck, editor

Volume Publisher: University of Chicago Press

Volume ISBN: 0-226-53680-7

Volume URL: http://www.nber.org/books/morc05-1

Conference Date: June 21-22, 2003

Publication Date: November 2005

Title: A Frog in a Well Knows Nothing of the Ocean: A History of Corporate Ownership in Japan

Author: Randall Morck, Masao Nakamura

URL: http://www.nber.org/chapters/c10274 


\title{
A Frog in a Well Knows Nothing of the Ocean A History of Corporate Ownership in Japan
}

\author{
Randall K. Morck and Masao Nakamura
}

\subsection{Introduction}

An ancient Japanese proverb speaks of a frog prideful of the beauty at the bottom of his well and ignorant of the world beyond. The history of Japanese corporate governance is especially interesting because the Japanese literally searched the world for the best institutions of capitalism, and changed their institutions more radically and more often than in any other major industrial economy. These changes, and the associated successes and failures associated, illuminate fundamental issues of corporate governance, corporate control, and the economics of institutions.

Historical and contemporary research into corporate ownership in Japan both focus on intercorporate networks. In the last third of the twentieth century, the interfirm networks of interest are horizontal and vertical keiretsu groups. Horizontal keiretsu, like the Mitsui group, are interindus-

Randall K. Morck is the Stephen A. Jarislowsky Distinguished Professor of Finance in the School of Business, University of Alberta, and a research associate of the National Bureau of Economic Research (NBER). Masao Nakamura is Konwakai Japan Research Chair and professor at the Sauder School of Business and the Institute of Asian Research, University of British Columbia.

We are grateful for comments by Sheldon Garon, Akiyoshi Horiuchi, Yishay Yafeh, and two anonymous reviewers on an earlier version of this paper, entitled "Been There, Done That: The History of Corporate Ownership in Japan.” We are also indebted for useful suggestions to Barry Eichengreen, Masaharu Hanazaki, Katsuyuki Kubo, Richard Sylla, Seki Obata, Dwight Perkins, Juro Teranishi, Yupana Wiwattakantang, and participants in the NBER History of Corporate Ownership conference. The Rise and Fall of Great Business Families at Lake Louise in 2003, the European Corporate Governance Network (ECGN)NBER-University of Alberta-INSEAD conference of the same name at Fontainebleau in 2004, the Strategy and Business Economics seminar at the University of British Columbia, and the Hitotsubashi University Workshop on Corporate Governance in East Asia. This research was done while Randall K. Morck was visiting Hitotsubashi University in Tokyo. 
try networks of firms whose small individual equity stakes in each other collectively sum to control blocks. Vertical keiretsu encompass the suppliers and customers of a single large firm, such as Toyota Motors. In both variants, public shareholders only have access to minority interests, rendering them essentially irrelevant to corporate governance. Adjunct to the keiretsu networks, most Japanese firms have strong ties to their lead lenders, or main banks.

However, keiretsu are a relatively recent development. During the feudal Takagawa period (1603-1868), Japanese firms were owned entirely by families - or, perhaps more properly, by clans. The Mitsui and Sumitomo family businesses both emerged during this era. In both cases, extensive sets of family rules and traditions determined corporate governance issues.

Following the Meiji Restoration of 1868, the new government promoted rapid industrialization. The Mitsuis, Sumitomos, and other new family businesses like Mitsubishi (run by the Iwasakis) needed capital vastly in excess of their own wealth, and they turned to public equity markets. The families organized a new firm to float equity for each new venture and organized them into pyramidal groups. At the apex of each was a family partnership (later a family corporation), which controlled several public corporations, each of which controlled other public corporations, each of which controlled yet other public companies, and so on. These structures, called zaibatsu, resembled modern Korean chaebol and similar pyramidal groups elsewhere. ${ }^{1}$ Despite much research, the contributions of zaibatsu to the rapid development of the prewar period remain unclear. The zaibatsu were clearly key players in this development. But questions remain about whether powerful zaibatsu families grew overly concerned about preserving their wealth and control, and avoided high-risk projects in new industries that might have further accelerated Japan's modernization. Also, zaibatsucontrolled banks that lent solely to other firms in their zaibatsu failed during the interwar depressions, exposing problems inherent in related lending.

During World War II, Japan de facto nationalized many major corporations, subordinating them to central planners. ${ }^{2}$ The Temporary Funds Adjustments of Law of 1937 created the Kikakuin, or Planning Agency, to centralize economic planning and administration. This required corporate boards to obtain government approval for most important decisions, such

1. The Kanji characters for zaibatsu are pronounced chaebol in Korean. One sees a stricter adherence to blood kinship in the governance of chaebol. Confucianism, influential in Korean cultures, extols respect for family, while Japanese Buddhism allows more leeway for sidelining inept blood kin.

2. Central planning in Japan involved rigid central plans, state command and control over all aspects of the economy, and the de facto abolition of ownership rights for capital. However, de jure private ownership of land was retained, as in communist Poland, as was de jure private ownership of zaibatsu and many other private-sector corporations. Japanese central planning was corporatist, rather than socialist, though much rhetoric of the period obscures this. 
as changing their articles of incorporation and issuing equity or debt. Further government decrees abolished boards' rights to set dividends in 1939 and to appoint managers in 1943, reassigning these powers to Kikakuin. Although established by an extreme right-wing government, the Kikakuin consciously imitated many of the planning methods the Soviet Union used for its heavy industrialization in the 1930s. ${ }^{3}$ As in Nazi Germany, this was accomplished amid much condemnation of "shareholders" (meaning the controlling shareholders, or zaibatsu families) for their self-interest, risk aversion, and unpatriotic myopia. This rhetoric would resurface later as a justification for depriving small shareholders, rather than controlling shareholders, of governance input.

Following the war, Japan was governed by the United States military from 1945 to 1952. General MacArthur broke up the zaibatsu. Consequently, Japan was briefly a widely held economy, like the United States and United Kingdom, in which most large public companies had no controlling shareholders. Japanese firms undertook hostile takeovers of each other, and raiders extracted greenmail from unwilling target firms.

Following the end of the U.S. occupation in 1952, Japanese firms began preempting takeovers by acquiring white squire positions in each other. ${ }^{4}$ The major banks were often key in organizing these intercorporate equity placements. These holdings grew into the keiretsu system in the 1950s and developed more fully in the 1960s. That system, which still characterizes Japanese big business, is now under growing stress. At the beginning of the current century, Japan is once again bracing for major institutional changes.

Throughout all of these changes, the principals of Japan's great businesses actively pursued their own interests, balancing profit and control. In general, they shaped and reshaped organizational forms to accommodate this balance as new legal and other constraints emerged. This paper examines the emergence and evolution of these different organizational structures as responses to changing political and institutional circumstances.

Of course, institutional changes also reflected lobbying by big business. However, critical points in Japan's business history seem to involve exogenous events that clearly required adaptation by the business sector. The abrupt opening of Japan to world trade and the decision of the Meiji government to embark on a crash program of modernization are examples. The generally negative attitudes of both the Japanese military government and the Allied occupation force in the mid-twentieth century to the great zaibatsu families are two others.

Many factors underlie the rise of zaibatsu and the organization of keiretsu-economies of scope and scale, reputation, the circumvention of

4. A white squire is a friendly firm that buys a block of stock in a target firm to protect it from a raider. If the friendly firm takes the target over entirely, it is called a white knight. 
flawed markets and institutions, and numerous other factors. However, we argue that the primary purpose of both zaibatsu and keiretsu was to protect the control rights of the great zaibatsu families and of professional managers, respectively. The zaibatsu families and keiretsu managers, especially main bank managers, also apparently benefited from political ties at certain times. This allowed both to become entrenched, and sometimes to retain governance powers they might otherwise have forfeited.

This paper is organized as follows. Section 7.2 describes the initial state of ownership of Japan's largest businesses immediately prior to the country's industrialization. Section 7.3 describes the formation and development of Japan's great zaibatsu in the late nineteenth and early twentieth centuries. Section 7.4 details the culling of Japan's corporate sector that took place in the 1920s and 1930s, as the country endured tandem depressions. Section 7.5 describes the imposition of a centrally planned economy by the military in the late 1930s and 1940s. Section 7.6 describes the U.S. occupation and the reconstruction of Japan as a widely held economy with Anglo-American corporate governance. Section 7.7 describes the modification of this system into the present keiretsu ownership structures. Section 7.8 reflects on the economics underlying the zaibatsu and keiretsu, and attempts to distill lessons from Japan's corporate governance history. Section 7.9 concludes.

Finally, we acknowledge a pervasive debt throughout this chapter to Hirschmeier (1964), Hirschmeier and Yui (1981), McMillan (1984), Nakamura and Odaka (2003), and Yafeh (2004) for general background information. We are also grateful to Teranishi (2003), who made an English draft of his volume available to us, also as general background information. To avoid repetition, these sources are not cited except where we specifically stress particular points they highlight.

\subsection{Initial Conditions: The Tokugawa Economy}

Acemoglu, Johnson, and Robinson (2001), Glaeser and Shleifer (2002), and other students of institutional economics stress the importance of very early historical events. We therefore begin with an overview of the economy of preindustrial Japan.

Japan's first contact with the Western world was a 1542 Portuguese trading expedition. At the time, Japan was divided into warring principalities. By 1590 , General Hideyoshi Toyotomi had united the country by force. To pacify it, he demanded absolute submission from every part of society. Foreign merchants and missionaries interfered with this submission, so Hideyoshi persecuted and expelled foreigners. ${ }^{5}$

Hideyoshi died in 1598 after a failed invasion of Korea, and his comrade

5. Japanese shoguns and warlords are often cited by their first names. 
General Ieyasu Tokugawa quickly took charge. By 1603, Ieyasu had defeated rival warlords, many backed by foreigners, and was appointed shogun by the emperor in Kyoto. He established a government in Edo (renamed Tokyo in 1868 when the emperor moved there from Kyoto), and his line would govern Japan as shoguns for over 250 years. Tokugawa froze an already rigid caste system, ${ }^{6}$ with samurai warriors at the top, peasants in a second tier, craftsmen below them, and merchants in the bottom stratum. ${ }^{7}$ Unsurprisingly, this moral inversion resulted in a prolonged economic stagnation, exacerbated by a code of chivalry, called bushido, that glorified honor above all else, entrusted all samurai with the power of life and death over the lower castes, forbade the higher castes from transacting business, and disparaged the pursuit of wealth as dishonorable.

Nonetheless, Ieyasu promoted foreign trade as he suppressed Christianity. But the third Tokugawa shogun, his grandson Iemitsu, concluded that trade and ideas were inseparable. Consequently, in 1633 he forbade traveling abroad, banned foreign books, and proclaimed a death sentence on foreigners found outside a small enclave in Nagasaki. Although some foreign books seeped in again after 1720, this early antiglobalization backlash continued to hermetically isolate Japan.

Although foreign trade was prohibited, domestic trade continued, and many merchant families grew wealthy. The Mitsui dynasty was founded by Hachirobei Takatoshi Mitsui (1622-94), a silk merchant who expanded into other commodities because of his extensive use of barter. The Sumitomos, who grew wealthy mining and smelting copper, apparently started in Kyoto and then moved to Osaka in the early Edo period. Both families established complicated house rules - constitutions governing all aspects of business. Power was divided between a patriarch and a family council, which served a quasi-parliamentary function.

For example, the Mitsui family consisted of eleven founding clans and devised elaborate rules for maintaining a balance of power among them. Representatives from each clan participated in management. The Mitsui house rules prohibited the founding clans from withdrawing their ownership shares and prohibited other branches of the family from gaining ownership rights. Voting power in the family council passed to the eldest sons of each founding clan. Younger sons could serve as managers or could be given start-up funding. The Mitsui family was known for adopting com-

6. The basis for this system dates to Hideyoshi Toyotomi (1536-98), a shogun who was born as a peasant, became an adopted samurai soldier, and conquered Japan after confiscating the weapons of peasants and religious institutions in 1588 . Worrying that social mobility might produce another Hideyoshi, he made castes permanent and hereditary in 1590 . None but samurai could carry weapons or wear armor. Despite this, some fluidity reappeared - for example, some feudal lords in the Edo era sponsored sumo wrestlers to become samurai and carry two swords. Because of this, contemporary historians typically use the more ambiguous term status group, rather than caste.

7. Only eta, outcasts with unclean professions, were lower. 
petent hired managers through marriage to Mitsui daughters. ${ }^{8}$ Additional house rules governed the disposition of property, marriage, divorce, adoption, and inheritance, and were strictly enforced at family councils to avoid intrafamily feuds. House rules forbade any Mitsui from bringing any family dispute to the public courts, becoming involved in politics publicly, creating debts, and guaranteeing debts. Involvement or investment in any nonfamily business and serving in public office were proscribed unless the Mitsui council granted an exception. ${ }^{9}$

Mitsui assets were divided into three classes. Business assets belonged to the entire Mitsui family, and the house rules permitted no division of them among the clans. Common assets were used for disasters and emergencies, and so served as a sort of insurance fund. Each clan managed its common assets as it chose, and the principal passed from generation to generation, but accumulated returns did not. When a clan patriarch died, the family council redistributed these gains among the eleven clans to preserve the rankings of the eleven founding clans. Clan assets were the undisputed property of the individual clans and could not be redistributed by the family council under normal circumstances.

The Sumitomo zaibatsu began when Tomomochi Soga, who married into the Sumitomo family and adopted its name, successfully reproduced a copper-smelting method he had learned of from a Western merchant in Osaka. The method, which uses lead to extract silver and other impurities from copper ore, increases the efficiency of copper smelting drastically and remained in use in Japan until the late nineteenth century. Soga built a copper refinery in Kyoto in 1590 and then (with his father) opened a business in Osaka to license the new copper-smelting method to competitors. This concentrated virtually all Japan's copper smelting in Osaka and earned Soga as much respect as a merchant might gain. He marketed his copper products using the trade name Sumitomo Izumiya. In 1691 the family began mining copper at Besshi for the Shogunate. ${ }^{10}$ This proved extraordinarily lucrative, and financed virtually all subsequent Sumitomo businesses - including textiles, clothing, sugar, and medicines. Subsequently, one Sumitomo clan began a money exchange firm.

The Sumitomo family code resembled the Mitsui code in many ways.

8. Adoptions, like marriages, had to be approved by the Mitsui family council. An important example of this is Rizaemon Minomura (1821-77). Born to an unemployed samurai in Nagano, he migrated to Edo. While working for a merchant, he negotiated with Mitsui. Mitsui hired him in 1866 and ultimately adopted him into the family as head of the Minomura clan, one of the eleven at the Mitsui family council. (He adopted the Minomura name.) $\mathrm{He}$ subsequently held various key positions with Mitsui companies. In 1876 he reorganized the family money exchange operation into the Mitsui Bank and became its president. Rizaemon Minomura later adopted a merchant's son, Risuke Minomura (1843-1901).

9. See Yasuoka (1984) for details.

10. The Besshi copper mine remained in operation until 1973 and produced 700,000 tons of copper during its lifetime. 
However, a few differences are worth noting. The Sumitomo code provided for its own revision, declaring a consensus of the council sufficient to change the code. ${ }^{11}$ Perhaps more important, the Sumitomo code had no provision governing inheritance or requiring continued family dominance. Nonetheless, family control was preserved, probably because of two other differences. First, the Sumitomo patriarch led a symbolic existence. He gave formal approval to matters set before him, but the council actually made all significant decisions. This prevented one clan from dominating and creating a situation in which other clans might want out. Second, all family disputes, even ones within a single Sumitomo clan, had to be referred to the council. This made the council aware of discontent within clans at early stages. It also created a much more centralized management structure than in the Mitsui group. Very detailed reporting of anything extraordinary to the upper ranks was required. ${ }^{12}$

Famines, riots, and especially a growing financial dependence of samurai on merchants slowly weakened Tokugawa rule. The Mitsui and Sumitomo families served the government in all manner of commercial and financial dealings. This "corruption" (by the standards of bushido) undermined Tokugawa legitimacy, as did incompetence and declining morality among the Tokugawa leadership. From the late eighteenth century on, Russia and other European nations tried to force Japan's market open. In 1853 and 1854, the American commodore Perry bombarded Edo until the Tokugawa government agreed to open a few ports to foreign trade.

However, foreign trade remained very limited until the Meiji Restoration in 1868. Contemptuous of the Tokugawas' increasingly craven attitude toward foreigners, a group of samurai captured the emperor and seized power, claiming legitimacy by restoring his rightful rule. In fact, the imperial family, which provided titular emperors in Kyoto throughout the Edo period, had been symbolic throughout Japanese history. Real power remained with these samurai now as well. Nonetheless, this era is called the Meiji Period, in honor of the emperor who reigned from 1868 to 1912.

\subsection{Early Industrialization Following the Meiji Restoration}

The new Meiji rulers quickly realized that, to gain freedom from foreign pressure, Japan needed Western technology and therefore Western ideas. They dispatched a cadre of Japan's brightest students to study abroad and return with descriptions of foreign institutions. The government then launched a two-decade program of modernization, copying what they perceived to be best practice abroad. This period in Japan's history closely resembles some of the "shock therapy" reforms of the 1990s in post-Socialist 
states. In rapid fire, the new government introduced democracy modeled on the German Diet, compulsory education modeled on the French and German school systems, universities and an army modeled after those of Prussia, and a navy modeled after the British Royal Navy. Religious freedom, social mobility, and land reform quickly undermined both bushido and the caste system.

But most important, the Meiji government introduced the institution of capitalism. During its crash modernization, Japan adopted a legal system largely based on German civil law. Public bond trading began in the 1870s, and in 1878 the Tokyo and Osaka Stock Exchanges were formed and subjected to regulation under the Stock Exchange Ordinance. Leading merchant families issued stock to finance industrialization, and the great pyramidal zaibatsu groups that came to dominate Japan formed.

A central problem Meiji governments confronted was the distaste of the great mercantile families for pooling their capital with that of outsiders. On the one hand, the government wanted Japan's existing large businesses to grow, and this required respecting the sensibilities of their principals. On the other hand, the Meiji leaders knew that economic growth required strangers to pool capital. Apparently with government prodding, the Mitsuis, the Onos, and several other families formed the First National Bank. Yet the Mitsui and Ono families could not get along. Dissatisfied, the Mitsuis founded the Mitsui Bank in 1876. Similarly, after the Yasudas and Kawasakis set up the Third National Bank, the Yasudas set up their own Yasuda Bank in 1880.

This tension created apparent inconsistency in Meiji legal codes. For example, the 1896 civil code stipulates that "joint owners of property can demand their due shares of the property at any time." Yet the same code grants the head of a family control of family property, including that of subfamilies, "to provide for their future support." The same tension affected the evolution of the zaibatsu.

\subsubsection{Defining a Zaibatsu}

Before proceeding further, it is useful to define zaibatsu, a term replete with the ambiguity Japanese so admire. Many academics and others, both inside and outside Japan, use the term to refer to all the large business groups in the country prior to World War II. However, beyond that, there is no clear-cut unified definition of a zaibatsu. Several ambiguities are noteworthy.

First, the Japanese business and economic history literature generally holds that the zaibatsu developed in the Taisho period (1912-26) after World War I. ${ }^{13}$ This seems to be because the term zaibatsu came into use in

13. Historians assign periods corresponding to the reigns of emperors. The Meiji period is from 1868 to 1912, the Taisho period is from 1912 to 1926, and the Showa period is from 1926 to 1989. Note that emperors choose official names upon their ascension. Thus in 1926, Hirohito chose the official name Showa, meaning enlightened peace. 
discussions of income distribution and monopoly capital (and Marxism) in the Taisho period. However, both the Mitsui and Sumitomo groups, always listed among the zaibatsu, formed long before this. Other major groups, like the Mitsubishi and Yasuda zaibatsu, became important in the Meiji period (1868-1912). Yet other zaibatsu clearly formed after World War I.

Second, even though zaibatsu typically implies family control, the oftencited list of the ten main zaibatsu (table 7.1) includes Nissan. As we show below, no family voted a majority of Nissan's stock through most of its existence. Nevertheless, Yoshisuke Aikawa and his family successfully maintained control until the end of World War II.

Third, zaibatsu were often thought to have substantial monopoly power in many, not just a few, industries. Indeed, the U.S. military government used industry market shares to ascertain whether or not a group was a zaibatsu and thus to be broken up. Fourth, zaibatsu are often thought to have been relatively independent of bank financing. Fifth, zaibatsu were business groups with vast land holdings, under which lay great mineral wealth. Sixth, a zaibatsu was sometimes defined as a group of firms connected with, and dependent on, a general trading firm, or sogo shosha. Seventh, the term zaibatsu is now sometimes extended to cover family-controlled groups of listed companies in developing economies in general.

Table 7.1 Ten zaibatsu combines designated by the Holding Companies Liquidation Commission (HCLC) for dissolution

\begin{tabular}{lccc}
\hline Zaibatsu & $\begin{array}{c}\text { Number of } \\
\text { subsidiaries } \\
\text { in } 1937\end{array}$ & $\begin{array}{c}\text { Number of } \\
\text { subsidiaries } \\
\text { in } 1946\end{array}$ & $\begin{array}{c}\text { Paid-in capital } \\
\text { as \% of Japan's } \\
1946 \text { total }^{\mathrm{a}}\end{array}$ \\
\hline Mitsui & 101 & 294 & 9.4 \\
Mitsubishi & 73 & 241 & 8.3 \\
Sumitomo & 34 & 166 & 5.2 \\
Yasuda & 44 & 60 & 1.6 \\
Total & 252 & 761 & 24.5 \\
Nissan & 77 & 179 & 5.3 \\
Asano & 50 & 59 & 1.8 \\
Furukawa & 19 & 53 & 1.5 \\
Okura & 51 & 58 & 1.0 \\
Nakajima & - & 68 & 0.6 \\
Nomura & - & 19 & 0.5 \\
Total & 197 & 439 & 10.7 \\
Top ten zaibatsu total & 449 & 1,200 & 35.2 \\
\hline
\end{tabular}

Sources: HCLC volumes as cited in Hadley (1970), Takahashi and Aoyama (1938, pp. 15152).

aJapanese government estimates for Japan's paid-in capital in 1946 are 32 billion yen (Ministry of Commerce and Industry), 43 billion yen (Ministry of Finance), and 48 billion yen (Bank of Japan). The HCLC used the Ministry of Commerce and Industry estimate without any explanation in deriving these figures. 
Finally, zaibatsu had pyramidal structures. A family holding company or partnership controlled a set of directly owned subsidiaries, which then controlled other firms, which then controlled yet other firms, and so on. The family usually had an operating decision rule for determining which firms to own directly versus indirectly. Figure 7.1 illustrates the stylized structure of a pyramidal corporate group. As we show below, the vague definition of zaibatsu in the minds of the Japanese and foreign architects of the postwar system may be, at least in part, responsible for their less-thancomplete dissolution after the war.

We use the term zaibatsu to denote any large pyramidal group of listed firms. This distances the term from both origin and control, from contentious issues like monopoly power or land rents, and from difficult-to-

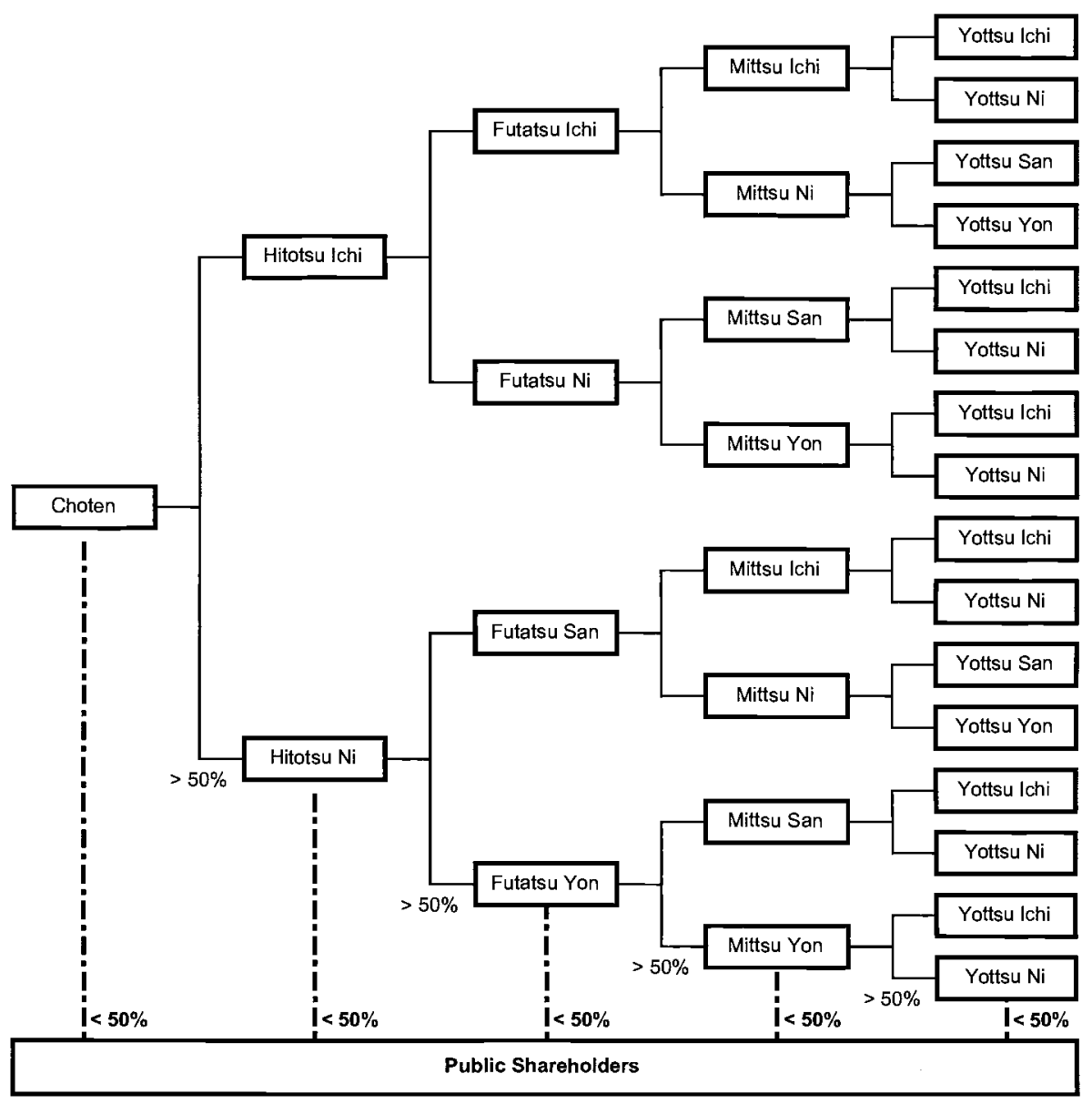

Fig. 7.1 A stylized representation of a zaibatsu control pyramid 
measure concepts like the importance of bank financing or general trading firms. It also distinguishes the pyramidal zaibatsu from the keiretsu groups of postwar Japan, whose structure of intercorporate ownership is not pyramidal.

We use the term apex firm to denote the family-controlled entity at the top of the pyramid. Firms whose shares it holds we refer to as directly controlled subsidiaries. Firms it controls but whose shares it does not hold we call indirectly controlled subsidiaries. Indirectly controlled subsidiaries can be controlled by either directly controlled subsidiaries or other indirectly controlled subsidiaries. These terms are illustrated in figure 7.1.

\subsubsection{Zaibatsu Formation}

The development of zaibatsu (and other firms) was relatively unhindered by government intervention until the 1930s. Few regulations existed in financial markets, yet capital markets provided 87 percent of the new capital required by Japanese corporations in 1931. Rajan and Zingales (2003) describe a substantial stock market in early twentieth-century Japan, despite the absence of statutory shareholder rights. Corporate governance was generally in the hands of controlling shareholders-usually wealthy families. Banks had little or no corporate governance role. Public shareholders bet on the honesty of insiders.

The main zaibatsu families first expanded beyond their traditional businesses when the Meiji government undertook a mass privatization in 1880. The state had established industries it deemed essential to modernization but had accumulated a huge public debt doing so. To solve this fiscal problem, the government implemented a mass sell-off of state-owned enterprises in all areas except munitions. Included were factories producing virtually all important manufactured goods - steel, cement, coal, metals, machines, ships, textiles, and so on.

The main buyers, Mitsui, Mitsubishi, Sumitomo, and a few other zaibatsu, thus entered new lines of business. ${ }^{14}$ Although there was no clear-cut method of allocating state-owned factories, each of the three main zaibatsu ended up with some assets in each key industry: mining, shipbuilding, machinery, textiles, and so on.

\subsubsection{Zaibatsu Expansion and the Problem of Preserving Insider Control}

One of the most important corporate governance considerations for business families during this period was preserving family control while satisfying an ever-growing need for capital. Families that kept their firms unlisted found this growing need for capital a serious problem.

Such problems were not new. As the number of relatives grew with each

14. Some historians consider this the beginning of Japan's zaibatsu. 
generation, preserving meaningful control for the patriarch had always presented problems. As mentioned above, and illustrated in table 7.2, the Mitsui family redistributed assets to the different clans of the Mitsui family continuously since its foundation in 1694 . The stakes are remarkably stable.

Nonetheless, the Mitsui patriarch dictated most family businesses decisions. This system, divided ownership with an imposed centralized control that largely negated the rights of individual owners, grew increasingly difficult to maintain. The problem grew even worse when the Meiji government

Table 7.2

Ownership shares of the Mitsui families

\begin{tabular}{|c|c|c|c|c|}
\hline $\begin{array}{l}\text { Mitsui family member } \\
\text { in } 1694\end{array}$ & $\begin{array}{c}1694 \\
\begin{array}{c}\text { Takatoshi's } \\
\text { will }^{\mathrm{a}}\end{array}\end{array}$ & $\begin{array}{c}1722 \\
\text { Takahira's } \\
\text { will }^{\mathrm{b}}\end{array}$ & $\begin{array}{c}\text { 1867-1873 } \\
\text { End of } \\
\text { Edo/Meiji Rest. }\end{array}$ & $\begin{array}{l}1909 \text { Mitsui } \\
\text { partnership } \\
\text { established }\end{array}$ \\
\hline \multicolumn{5}{|l|}{ Mitsui, Takatoshi's sons } \\
\hline Oldest son & $29(41.5)$ & $62(28.2)$ & $62(28.2)$ & $230(23.0)$ \\
\hline $\begin{array}{l}\text { Second oldest son } \\
\text { (Takahira) }\end{array}$ & $13(18.6)$ & $30(13.6)$ & $30(13.6)$ & $115(11.5)$ \\
\hline Third oldest son & $9(12.9)$ & $27(12.3)$ & $27(12.3)$ & $115(11.5)$ \\
\hline Fourth oldest son & $7.5(10.7)$ & $25(11.4)$ & $25(11.4)$ & $115(11.5)$ \\
\hline Sixth oldest son & $4.5(6.4)$ & $22.5(10.2)$ & & \\
\hline Ninth oldest son & $1.5(2.1)$ & $22.5(10.2)$ & $22.5(10.2)$ & $115(11.5)$ \\
\hline $\begin{array}{l}\text { Tenth oldest son } \\
\text { (merged with sixth) }\end{array}$ & $1.2(2.1)$ & & $22.5(10.2)$ & $115(11.5)$ \\
\hline \multicolumn{5}{|l|}{ Other relatives and wife } \\
\hline 1 Takatoshi's wife & $\begin{array}{l}100 \text { kanmed }^{d} \\
\text { of silver }\end{array}$ & & & \\
\hline 2 & $2(2.9)$ & $8(3.6)$ & $8(3.6)$ & $39(3.9)$ \\
\hline 3 & $1.5(2.1)$ & & & \\
\hline 4 & $0.8(1.1)$ & $6(2.7)$ & $6(2.7)$ & $39(3.9)$ \\
\hline 5 & & $7(3.2)$ & $7(3.2)$ & $39(3.9)$ \\
\hline 6 & & & $2.5(1.2)$ & $39(3.9)$ \\
\hline 7 & & & $3(1.4)$ & $39(3.9)$ \\
\hline Remainder & & $10(4.5)$ & $4.5(2.0)$ & \\
\hline Total & $70(100)$ & $220(100)$ & $220(100)$ & $1,000(100)$ \\
\hline
\end{tabular}

Note: Numbers in parentheses are percentages.

${ }^{a}$ The founder of the Mitsui family enterprise, Hachirobei-Takatoshi Mitsui (1622-94), began coownership of their family business. His 1694 will states that total family business annual profits be divided into 70 units for an annual distribution among his wife and sons.

${ }^{\mathrm{b}}$ Takahira, the second-generation head of the Mitsui family business, revised the profit distribution method in his 1722 will. The will states that total annual profits be divided into 220 units for an annual distribution among the family owners of the business. In this revision the ownership shares of the first and second sons' families were decreased, while the ownership shares of other family members and relatives were increased. These revised ownership shares remained unchanged for the following 150 years. ${ }^{\mathrm{c}}$ After the revision of the Mitsui family constitution was worked out during the first 20 years of the Meiji period, the Mitsui family partnership was created, and its ownership shares remained unchanged into the 1940s.

d 1 kanme is about $3.75 \mathrm{~kg}$. 
instituted new laws affirming individual ownership rights. Although these rights could be relaxed in family firms to preserve the power of the patriarch, this exemption did not extend beyond blood kin-for example, to share-owning employees.

This presented problems, for shareholders who were not blood kin had become common. It made sense to reward competent hired managers with shares. And sometimes competent hired managers, rewarded in other ways, grew wealthy and demanded the right to buy stock.

When the Meiji government established the civil code, large family businesses were usually recognized as general partnerships. As more outsiders supplied capital, and as each new generation created more insiders, these businesses found the legal status of a limited partnership advantageous. In 1893, when Japan enacted a commercial code, many zaibatsu holding company partnerships incorporated, though most remained unlisted. More new laws on ownership granted hired managers who had become shareholders a legal status equal to that of family members. This was difficult for the great families to accept, but the concept of random members of society buying and selling such a status was intolerable.

Even letting skilled managers and distant relatives hold shares often proved unbearable, and controlling families often went to considerable lengths to repair such perceived errors. For example, the Mitsui Bank, founded in 1876, soon had more than four hundred manager-shareholders. When the Mitsui group reorganized it as a general partnership in 1893, they bought up all of these shares. When the Kamoike zaibatsu family established the Thirteenth National Bank, forty distant relatives were shareholders. In 1897, the family's main branch bought them out and reestablished the bank as the Kamoike Bank, privately owned by the Kamoike patriarch. ${ }^{15}$

This sort of response is perhaps understandable, for successful family businesses operated with a common objective imposed by a core of family values, traditions, and history. Outsiders, even very competent ones, could not share fully in this, and their input would surely appear to the family as interference. Nevertheless, family firms closed to outsiders risked alienating their best managers and being shut out of the top end of the managerial labor market. Family businesses lacking management skill among blood kin, and unable to hire it, risked degeneration.

Some zaibatsu, most notably the Mitsui and Sumitomo zaibatsu, were particularly successful in growing rapidly without outside equity financing. Their success has been attributed to a series of highly competent hired managers, but their connections with important political leaders were certainly at least as important as their raw competence.

15. The Kamoike Bank subsequently became the Sanwa Bank, which evolved into the current UFJ Bank. 
The Sumitomo family owned a lucrative cash cow, the Besshi copper mines they obtained from the shogunate, and so could afford to keep more distant from the Meiji government - at least initially. The Mitsui group, however, needed the Meiji government's gratitude. They gained this by financing the struggling new government in its critical first years. In return, Mitsui was appointed government treasury agent, a duty that provided many opportunities.

To fulfill their treasury duties, the Mitsuis established a national network of branch offices. These generated cash flows from treasury business and served as bases for other trading. Business grew so fast that the Mitsui group had to set up the Kokusangata Karihonten, or Temporary Head Office for Domestic Trade, in Tokyo in 1874. Learning of the Meiji government's aim of promoting foreign trade, the Mitsui group began selling silk yarn and tea to Western merchants for commissions, and shipping imports between Tokyo and Yokohama. ${ }^{16}$ The Mitsui group's trading business, handled by employees steeped in Tokugawa traditions, lost money. In 1876, the Mitsui group was about to close its trading ventures when Kaoru Inoue (1835-1915), a leading Meiji politician, offered his Senshusha company to the Mitsui group to raise political funds. ${ }^{17}$ The Mitsui group jumped at this, for Senshusha came not only with government contracts but also with its top manager, Takashi Masuda, who trained at the largest American merchant house in Japan. The Mitsui group established Mitsui Bussan (Mitsui and Co.) in July 1876 by merging Senshusha and the Temporary Head Office for Domestic Trade, and appointed Masuda manager.

Mitsui Bussan's first government business was a monopoly selling coal from the state-owned Miike mine. Exporting Miike coal on commission to China through Shanghai was highly profitable, and Mitsui Bussan established its first foreign office in there late in 1876. This let Mitsui Bussan acquire international trade experience. Since Mitsui Bussan traded coal, like all other items, entirely on commission, its capital requirements were minimal. The only financing the Mitsui group provided was a $¥ 50,000$ overdraft allowance from the Mitsui Bank. In 1877, Mitsui Bussan made $¥ 200,000$ - a fortune at the time — supplying 60 percent of the military procurements for the Seinan War, a large operation to put down rebellion in Kyushu in 1877.

The Sumitomo and Mitsui houses were not the only great Takagawa merchant houses. But they were the only ones to expand their capital bases as the economy grew, and they were clearly the most adept at positioning

16. See Yamamura (1976).

17. Inoue subsequently served as minister of foreign affairs, the interior, and finance, and also as privy councilor. Senshusha, established in 1872 by Inoue and others, was a moderately successful trading business, mostly due to Inoue's political influence. Its primary business was executing government procurement orders for imports for Inoue's powerful political associates. Senshusha imported wool, guns, and fertilizer, and exported rice, tea, and silk. 
themselves to assist the government in implementing its economic policies. Other great business families of the Tokugawa era, such as the Kamoike zaibatsu, were less nimble, grew too slowly, and were gradually eclipsed.

Expanding the capital base by bringing in outsiders held a different danger. New investors could seize control, reducing the family to a limited partner. Both the Shimomura and Ohmura zaibatsu brought in outside investors who took control. Even worse from the perspective of the old families, the new controlling shareholders shifted the business out of their (money-losing) traditional Japanese clothing businesses and into department store-based retailing.

Despite its freedom from outside shareholders, the Mitsui group faced legal problems when different branches of the family began exerting their new rights as investors. Preserving control while accessing ever greater capital, whether from more distant relatives or strangers, became increasingly difficult.

\subsubsection{Pyramids as a Solution}

In his memoirs, Yoshisuke Aikawa (1934), the founder of the Nissan zaibatsu, describes pyramidal groups as an elegant solution to all of these problems - they preserve total control by insiders while permitting access to limitless capital. To see this, consider a family with a fortune of $¥ 1$ billion invested in a family business, Choten Corp. ${ }^{18}$ The family sees a multitude of profitable business opportunities and feels it could profitably invest many billions of yen. To see how the family can undertake all of these investments yet retain control of Choten and all these new ventures by constructing a pyramidal group, return to figure 7.1.

First, the family expands Choten Corp. by issuing new public shares worth almost $¥ 1$ billion. Public shareholders end up owning almost 50 percent of Choten, which is now worth almost $¥ 2$ billion. This gives the family almost $¥ 1$ billion in cash yet preserves its complete control of the family business. The latter is because its 50 percent-plus stake lets it appoint the board of directors. Choten is now set to become the apex firm of the pyramidal group.

Next, the family organizes two new firms, Hitotsu-Ichi Corp. and Hitotsu-Ni Corp. ${ }^{19}$ Each is financed with a $¥ 500$ million equity investment from Choten and a public offering to raise almost $¥ 500$ million by selling outside shareholders almost 50 percent. Hitotsu-Ichi and Hitotsu-Ni now each have $¥ 1$ billion. The family now fully controls three firms, with unconsolidated balance sheets totaling $¥ 4$ billion, and $¥ 3$ billion in consolidated assets. The family's control is complete because it fully controls

18. Choten is Japanese for apex.

19. In one Japanese counting system, hitotsu is one, futatsu is two, mittsu is three, and yottsu is four. In another, $i c h i$ is one, $n i$ is two, san is three, and yon is four. The appropriate use of the two systems is a matter of grammar. 
Choten, and Choten's board votes a 50 percent-plus stake in both HitotsuIchi Corp. and Hitotsu-Ni Corp., and thus controls their boards.

To expand further, the family has Hitotsu-Ichi and Hitotsu-Ni set up four new firms. Hitotsu-Ichi organizes Futatsu-Ichi and Futatsu-Ni, financing each with a $¥ 500$ million equity investment and a public offering to raise almost $¥ 500$ million by selling outside shareholders almost 50 percent. Hitotsu-Ni Corp. organizes Futatsu-San and Futatsu-Yon similarly. The family now fully controls seven firms, with unconsolidated values totaling $¥ 8$ billion and $¥ 5$ billion in consolidated assets.

In the next step, each Futatsu-level firm organizes two new companies. The family now fully controls fifteen firms, with unconsolidated balance sheets totaling $¥ 16$ billion and $¥ 9$ billion in consolidated assets. Each Mittsu-level firm can then similarly organize two Yottsu-level firms, resulting in a pyramid of thirty-one firms worth $¥ 32$ billion on paper and holding $¥ 17$ billion in consolidated assets. This process can be repeated until the family runs out of attractive investment opportunities. A pyramid with $n$ tiers contains $2^{n}-1$ firms, with unconsolidated book values totaling $2^{n}$ billion yen and consolidated assets worth $1 / 2\left(3+\sum_{v=1}^{\mathrm{n}} v\right)$ yen.

Thus, a five-tier pyramid lets the family raise $¥ 14$ billion in public equity but retain complete control. Had the family instead merely expanded their first company by issuing $¥ 14$ billion in additional Choten shares, their stake would have been diluted to one-fifteenth or 6.67 percent, and they would have lost control.

The elegance and simplicity of this solution, later extolled by Aikawa (1934), the founder of the Nissan zaibatsu, appealed to the great mercantile families, for they enthusiastically embraced this model to build the vast prewar zaibatsu. Both public investors and querulous relatives could be tapped for capital and excluded from corporate governance.

Of course, variations from this formula were possible. For instance, the controlling families often kept the apex firm of the pyramid unlisted. They thus used only family money to establish the first tier of subsidiaries. Since the Mitsui and Sumitomo families had both run highly profitable businesses for generations, their accumulated retained earnings easily let them skip the first step in the above recipe. In contrast, later groups, like Nissan, had public shareholders in their apex firms. Nonvoting or supervoting shares permitted much more leverage at each tier. Firms at different levels could also have real assets and engage in real business while serving as holding companies for firms in lower tiers. Actual pyramids were much messier than shown in figure 7.1, in that different levels of firms sometimes cooperated to control firms in all levels, including higher tiers of the pyramid. Nonetheless, figure 7.1 captures the essential logic of a pyramidal group.

Figures 7.2 and 7.3 illustrate the actual structure of the Mitsui group at its greatest extent. 


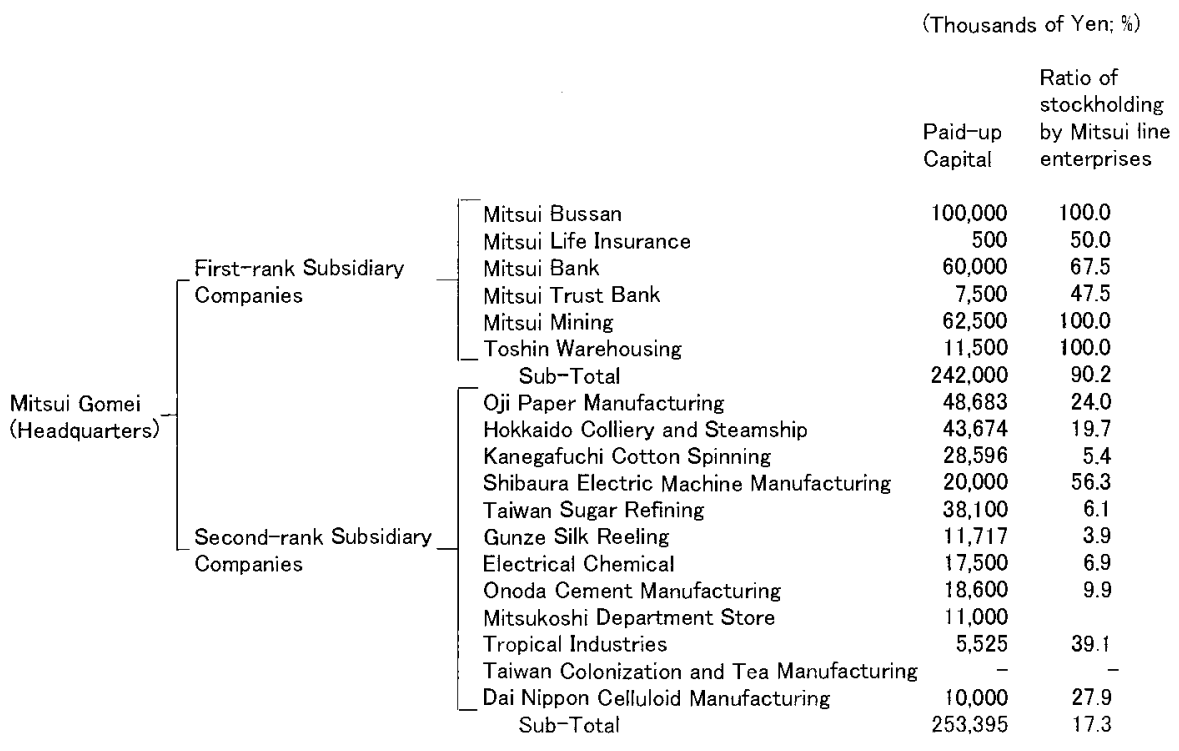

Fig. 7.2 The structure of the Mitsui zaibatsu in 1928

Japan, of course, was not the only country whose business tycoons came to appreciate pyramidal groups as a solution to the quandary of tapping public equity financing without risking the loss of corporate governance power. As the other chapters of this book show, zaibatsu were commonplace in Canada, the United States, and Europe during this period as well. And as La Porta et al. (1999) show, zaibatsu remain the most commonplace ownership structure everywhere except Japan, the United States, and the United Kingdom at the end of the twentieth century too, though the term pyramidal group is used outside Japan.

\subsubsection{The Big Four Zaibatsu}

While the Mitsui and Sumitomo zaibatsu may be said to have formed in the late nineteenth century in the sense that their pyramidal structures arose at that time, both have their true origins in the Tokugawa period. However, other zaibatsu were genuinely new. The largest were Mitsubishi and Yasuda. These four were the largest zaibatsu, so their development merits close inspection.

The founding of the Tokyo and Osaka Stock Exchanges in 1877 allowed Japanese companies to tap capital from individual investors. Mitsui and Sumitomo both began expanding by constructing pyramids. However, their first investments outside their primary lines of business were relatively small, experimental, and limited.

Thus, the Mitsui family, having begun as silk merchants, expanded into 


\section{井 \\ 合 Mitsui Partnership \\ 名}

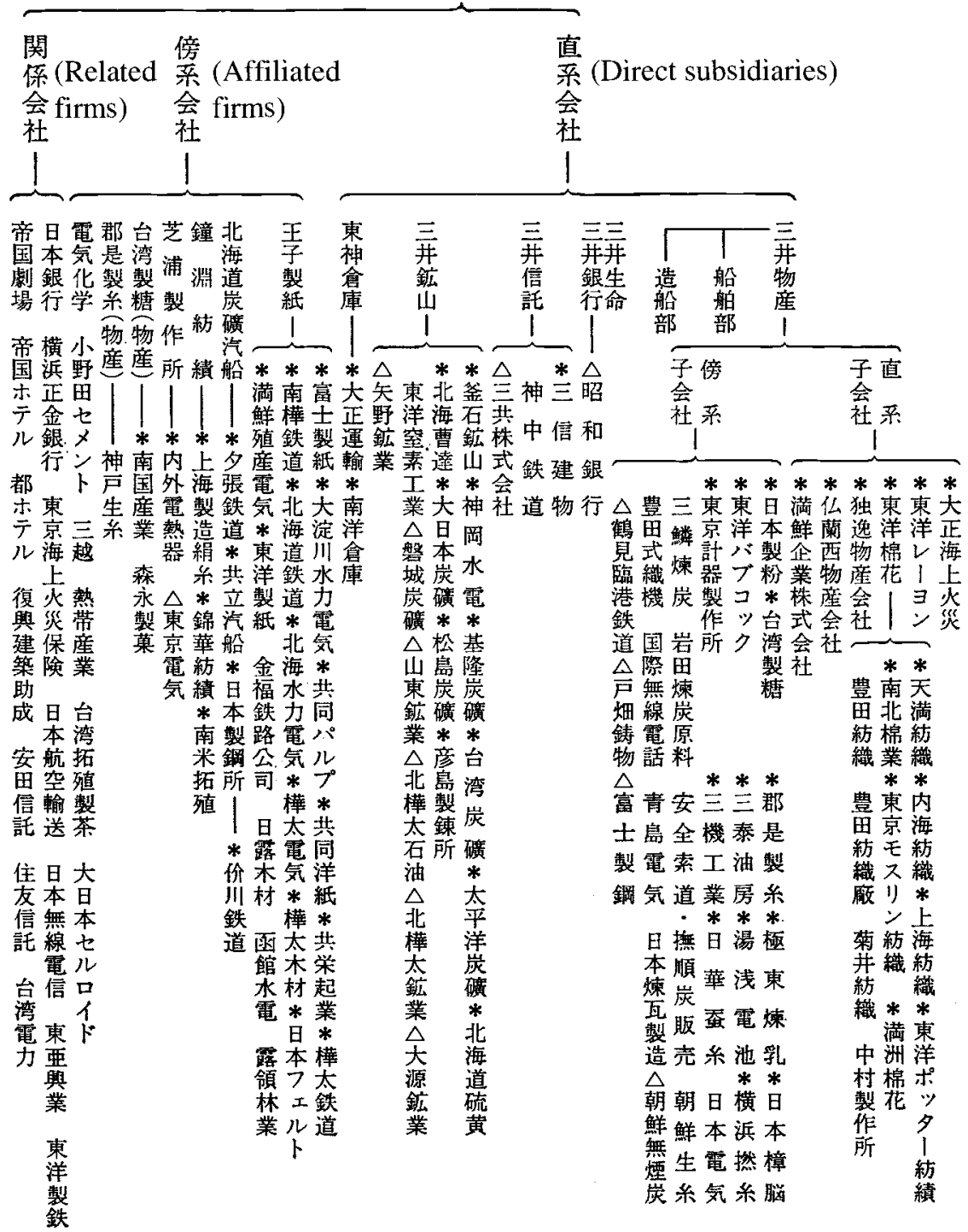

Fig. 7.3 Record of the structure of the Mitsui zaibatsu in 1930

Source: Takahashi (1930b, p. 50).

Notes: Mitsui's first-tier direct subsidiaries were Mitsui Bussan, Mitsui Life Insurance, Mitsui Bank, Mitsui Trust Bank, Mitsui Mining, and Toshin Warehousing (see also table 7.2). Mitsui Partnership owned and controlled fully its first-tier direct subsidiaries but did not necessarily fully control or own affiliated or related firms. More specifically, Mitsui Partnership controlled the firms with asterisks fully and the firms with no asterisks or triangles predominantly but not fully. Mitsui Partnership's control was weakest over the firms with triangles. 
areas related to clothing manufacture and sale. The family established trading operations in other commodities to facilitate barter transactions for silk, and a currency exchange operation to deal with foreign companies. However, the Mitsuis did invest significant capital more broadly from time to time. During the first twenty years of the Meiji era, the government established state-owned enterprises to develop strategically important industries. The Mitsui group often cooperated in these projects, and became the government's favored partner in many such ventures.

Toward the end of the nineteenth century, the government's fiscal problems necessitated a mass privatization of all state-owned enterprises, save armament factories, postal and telegraph systems, mints, and railroads. The magnitude of this mass divestiture was unprecedented. Between 1874 and 1896 alone, twenty-six major government projects - including coal, copper, silver, and gold mines; cotton- and silk-spinning mills; shipyards; cement factory; ironworks; sugar refinery; and glass factory-were transferred to private owners, usually the large zaibatsu.

However, except for these privatized enterprises, the great zaibatsu remained commerce based. Only at the century's end did they diversify further, and this was often at the prodding of hired managers, not family members. Extensive diversification would wait until after the First World War. Morikawa (1992, p. 27) argues that it took time for people knowledgeable of the possibilities opened by limited liability and stock markets to attain positions of influence.

Economic historians' assessment of the mass privatization is mixed.

The limited number of bidders, their political acuity, and the government's financial exigency perhaps made for bargain prices. The great zaibatsu families were well connected, and though some sales were auctions, others were negotiated privately. The great zaibatsu families were also virtually the only entities with pockets deep enough to participate extensively.

Certainly, most privatization prices were far lower than the Meiji government's capital outlays in establishing these enterprises. ${ }^{20}$ However, many state-owned enterprises were in dismal shape, and although many privatized enterprises subsequently encountered serious difficulties, the

20. For example, Takashima Coal Mine (government outlay by $1885, ¥ 393,848$ ) fetched $¥ 550,000$ in 1874 from Shoraisha, owned by Shojiro Goto, who resold it to Mitsubishi’s Iwasaki family in 1881. Other examples include the Shinmachi Silk Spinning Mill (setup cost $¥ 138,984$ ), sold to Mitsui in 1887 for $¥ 141,000$; the Nagasaki Shipyard $(¥ 1,130,949$ ), sold to Mitsubishi for $¥ 459,000$; Tomioka Filature ( $¥ 310,000$ ), sold to Mitsui in 1893 for $¥ 121,460$; the Sado Gold Mine $(¥ 1,419,244)$ and the Ikuno Silver Mine $(¥ 1,760,866)$, sold together to Mitsubishi in 1896 for $¥ 2,560,926$; and Kamaishi Ironworks ( $¥ 2,376,625)$, sold to Chobei Tanaka, an iron merchant and supplier for the Japanese army and navy, in 1887 for $¥ 12,600$. Tanaka subsequently sold Kamaishi Ironworks to his company, Kamaishi Mining, in 1924, and then divested it to Nippon Steel. Tanaka and the Kamaishi Mining succeeded spectacularly, gaining a 72 percent market share in pig iron by 1900 . The rarity of exceptions, such as the sale of the Miike Coal Mine (setup cost $¥ 757,060$ ), sold to Mitsui in 1888 for $¥ 4,590,439$, only accentuates the low privatization prices. For further details, see Kobayashi (1985), pp. 64-65. 
Japanese government rarely provided direct subsidies. When an 1889 earthquake destroyed the Kattate shaft of the Mitsui Miike coal mine, Finance Minister Matsukata refused Mitsui pleas, supported by cabinet ministers, for subsidies and a debt rescheduling. The Mitsuis completed their payments in 1902, as per the original agreement. Of course, the state did provide generous tariff protection and other indirect assistance to insure the success of the privatized enterprises.

Regardless of the government's intentions, many privatizations turned out to be plums. At the time, mining was highly profitable because of the expense of importing. Privatized mining companies, acquired by the Mitsui and Mitsubishi companies at this time, served as core cash cows until the mid-1950s, when major veins were exhausted. Most zaibatsu electric equipment manufacturers also developed by supplying equipment to their affiliated mining companies.

The positions of different firms within the zaibatsu pyramids were apparently of great concern. From time to time, weaker businesses were moved to lower tiers and stronger businesses to higher tiers.

For example, the Mitsui group's primary lines of business were still Japanese clothing and money exchange when the family diversified into banking in 1876. When Japanese clothing sales became shaky around 1873 , the family restructured the pyramid, moving that business to a lower tier and delegating its management to distant relatives. The Mitsui Bank became increasingly profitable and served as the apex firm of the Mitsui zaibatsu until 1893.

Again, in 1909, the Mitsui council restructured the pyramid, creating a holding company at the apex to control the Mitsui Bank, Mitsui Mining, and the trading firm Mitsui Bussan. This was accompanied by a major rearrangement of firms throughout the pyramid, with good performers moving closer to the apex and weak firms moving deeper into the pyramid. Morikawa (1980, pp. 46-57) and others argue that greater direct ownership by the Mitsui family indicates a greater family "concern" for a firm. The placement of undoubtedly key companies in deep levels of the Mitsui pyramid confutes this. For example, the Mitsuis moved Mitsukoshi, the direct descendent of their original silk business, to a low tier after its conversion into a Western-style department store chain in 1904. Oji Paper and Kanebo, firms of considerable national importance, were also low in the pyramid. Shibura Engineering Works, which merged with Tokyo Electric to form Tokyo Shibura (Toshiba) Electric in 1939, was also not a core Mitsui firm. ${ }^{21}$ General Electric had obtained 25 to 30 percent of Shibura in 1904 for technology licenses. ${ }^{22}$

21. Morikawa (1980) proposes that some Mitsui top managers and partners recognized the importance of Shibaura's operations but could not understand them. The Mitsui considered divesting Shibaura in 1902, but opposition from Mitsui Mining and others forestalled this. Shibaura went public as a Mitsui-group company in 1904.

22. Zaibatsu were often important technology importers; see Goto (1982). 
Amounts of shares held

\begin{tabular}{lcc}
\hline Company & Date & Shares held (paid-in book value, $¥ 1,000$ ) \\
\hline Mitsui Bussan & April 1910 & 1,699 \\
Mitsui Bank & December 1909 & 4,893 \\
Mitsui Partnership & January 1910 & 42,420 \\
\hline
\end{tabular}

It seems likely that firms' positions in the pyramids were also selected to facilitate tunneling - self-dealing to concentrate profits in firms owned directly by the Mitsuis and losses in firms merely controlled by them. This readily explains the better apparent performance of firms higher in the pyramids, and the location of many clearly important firms in lower tiers. ${ }^{23}$ Certainly, Shibura's performance in the early 1900s lagged behind that of other major Mitsui firms.

Records attest that the Mitsui head office carefully considered which companies to place where in the pyramid, and what stakes each company should hold in other group firms. As the zaibatsu grew ever more complex from 1912 to 1930 , the lower tiers were periodically drastically restructured, but the apex tiers changed little. The Mitsui Bank, Mitsui Bussan, Mitsui Mining, and Toshin Warehousing remained direct subsidiaries of the Mitsui partnership. The only significant change was the addition of the Mitsui Life Insurance and Mitsui Trust Bank as direct subsidiaries after $1912 .{ }^{24}$

Table 7.3 shows that the amounts of other companies' shares held by these three Mitsui firms were already significant by the early 1900s, though Mitsui Bussan's holding was relatively minor compared to the other two Mitsui family firms.

The Mitsui group's most intensive diversification began with Mitsui Mining's entry into chemicals in the early 1910s. Mitsui Bussan founded a shipbuilding company in 1917, purchased an iron and steel firm in 1924, and established Toyo Rayon to enter chemical textiles. This wave of diversification was undertaken exclusively through new subsidiaries of Mitsui Mining, the Mitsui Bank, and Mitsui Bussan, or through new subsidiaries of their subsidiaries. Table 7.4 shows the extent of this expansion, and figures 7.2 and 7.3 illustrate the structure of the zaibatsu at this point.

23. See, e.g., Claessens, Djankov, and Lang (2000), Claessens et al. (2002), Faccio and Lang (2003), Bertrand, Mehra, and Mullainathan (2002), and Johnson et al. (2000). Recent work suggests that tunneling is more common in countries whose minority shareholders are poorly protected, like Japan throughout its history. Shareholder rights were poorly protected before the war, and La Porta et al. (1999) assign Japan one out of six in an international comparison of shareholder rights. Porter (1990) argues that weak shareholder rights advantaged Japanese companies by freeing their managers from myopic shareholders, but Morck and Nakamura (1999) dispute this. At present, shareholder rights remain a controversial issue in Japan.

24. See Tamaki (1976, pp. 84-86). Fruin (1992, pp. 100-102) describes how the Mitsubishi pyramid was reorganized several times between 1916 and 1926 and argues that this reflected evolving strategic considerations such as economies of scope and scale. 


\begin{tabular}{lccc}
\hline & $\begin{array}{c}\text { Authorized capital } \\
\text { (millions of yen) }\end{array}$ & $\begin{array}{c}\text { Paid-in capital } \\
\text { (millions of yen) }\end{array}$ & $\begin{array}{c}\text { Mitsui Gomei } \\
\text { percent stake }\end{array}$ \\
\hline $\begin{array}{l}\text { Mitsui family holding company, } \\
\quad \text { Mitsui Gomei }\end{array}$ & 300 & 300 & n.a. \\
$\begin{array}{l}\text { Mitsui's designated subsidiaries } \\
\text { Mitsui Bank }\end{array}$ & 100 & 60 & 100 \\
Mitsui Bussan & 100 & 100 & 100 \\
Mitsui Mining & 100 & 62.5 & 100 \\
Toshin Warehousing & 15 & 12.5 & 100 \\
Mitsui Trust & 30 & 7.5 & 100 \\
Mitsui Life Insurance & 2 & 0.5 & 100 \\
Subsidiaries of Mitsui's designated & & & \\
$\quad$ subsidiaries & 11 & 5.5 & \\
Taiheiyo Colliery & 20 & 20 & \\
Kamaishi Mining & 10 & 10 & \\
Claude-Process Nitrogen Industries & 25 & 15 & \\
Toyo Cotton Trading & 10 & 10 & 56.4 \\
$\quad$ Toyo Rayon & & & $19.7^{\text {a }}$ \\
Mitsui's ordinary subsidiaries & 65.91 & 48.68 & 12.5 \\
Ojo Paper & 20 & 20 & 27.9 \\
Shibaura Engineering Works & 70 & 43.68 & 9.3 \\
Hokkaido Colliery \& Steamship & 30 & 30 & 6.9 \\
Nippon Steel Works & 10 & 10 & \\
Dai Nippon Celluloid & 60 & 28.6 & \\
Kanegahuchi Cotton Spinning & 31 & 17.82 & \\
Onoda Cement & 18 & 15 & \\
Denki Kagaku Kogyo & 15 & & \\
Mitsukoshi Department Store & & & \\
\hline
\end{tabular}

Sources: Shogyo Koshinsho (1930), Morikawa (1992)

Note: n.a. $=$ not applicable.

${ }^{a}$ Also 20.7 percent owned by Mitsui Mining.

Figure 7.4 shows the Sumitomo pyramid with a structure quite similar to the Mitsui pyramid. Financial institutions sit near the apex, and industrial firms fill lower tiers. Direct Sumitomo subsidiaries include a bank, sogo shosha, trust bank, insurance firm, mining company, and warehousing operation. Relatively fewer Sumitomo companies had publicly traded shares. The Sumitomo Bank went public in 1917, Sumitomo Trust in 1925, Sumitomo Chemical in 1934, Sumitomo Metal Industrials in 1935, and Sumitomo Electric Wire and Cable Works in 1937. Other Sumitomo firms remained unlisted until relatively late.

The Yasuda zaibatsu, whose structure also follows this pattern, is new compared to Mitsui and Sumitomo. The Yasuda zaibatsu began at the end of the Tokogawa era, when Zenjiro Yasuda (1838-1922), the son of a poor samurai in Toyama, moved to Edo and obtained work in a moneychanging house. In 1863 he began providing tax-farming services to the 


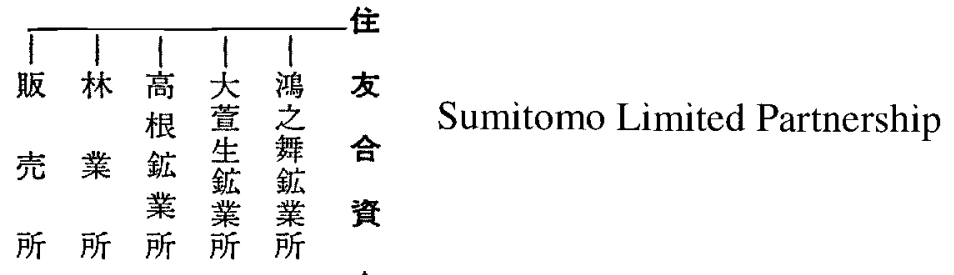

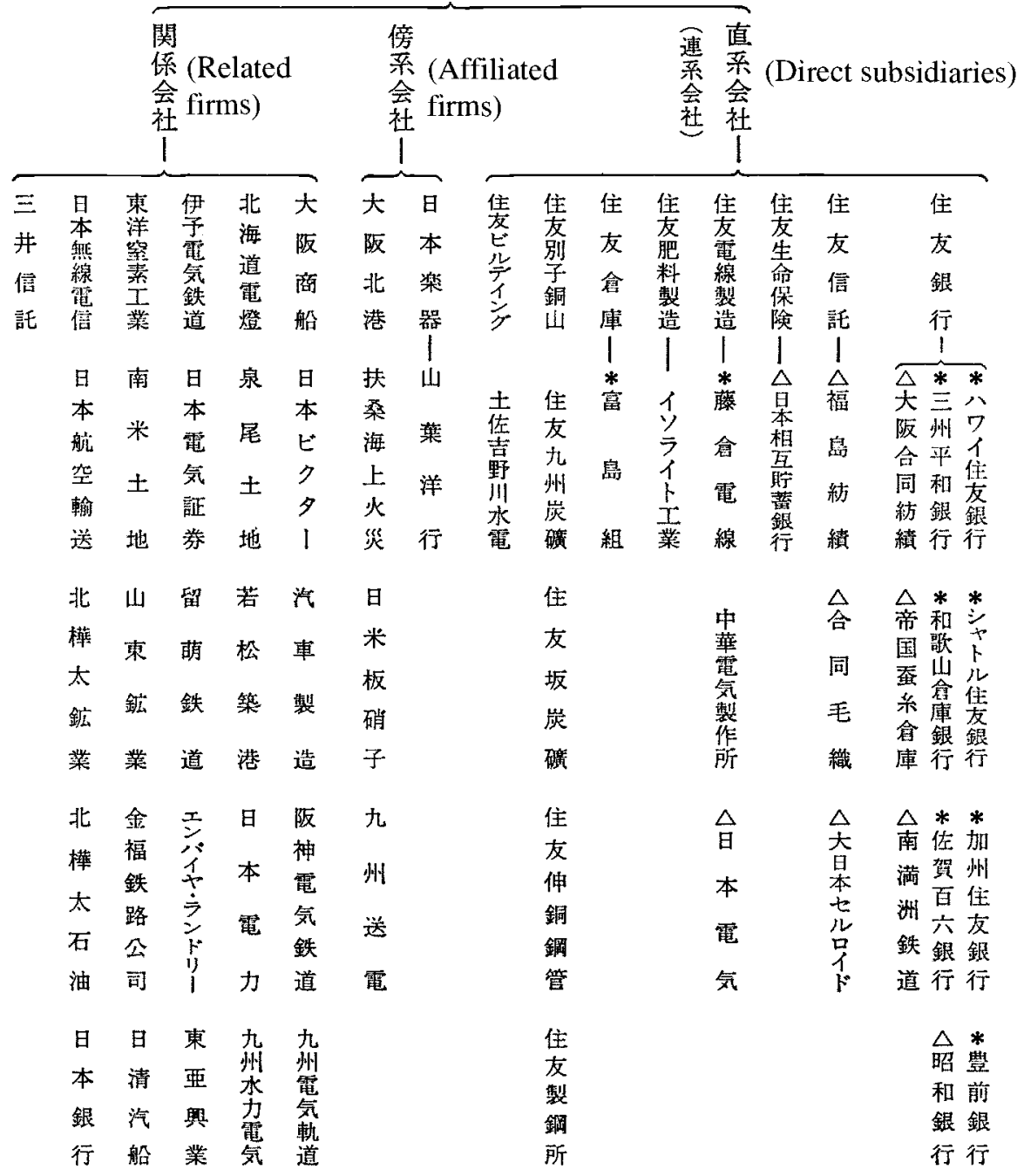

Fig. 7.4 Record of the structure of the Sumitomo zaibatsu in 1930

Source: Takahashi (1930b, p. 161).

Notes: Sumitomo's first-tier direct subsidiaries were Sumitomo Bank, Sumitomo Trust Bank, Sumitomo Life Insurance, Sumitomo Electric Wire and Cable Works, Sumitomo Fertilizer Manufacturing, Sumitomo Warehousing, Sumitomo Besshi Copper Mines, and Sumitomo Building. Sumitomo Limited Partnership owned and controlled fully its first-tier direct subsidiaries but did not necessarily fully control or own affiliated or related firms. More specifically, Sumitomo Limited Partnership controlled the firms with asterisks fully and the firms with no asterisks or triangles predominantly but not fully. Sumitomo Limited Partnership's control was weakest over the firms with triangles. 
shogunate, overseeing the collection and transport of silver and gold. After the restoration, he provided the same services to the Meiji. Yasuda profited from the delay between the collection of taxes and their forwarding to the government. He greatly magnified his wealth by buying up depreciated Meiji paper money that the government subsequently exchanged for gold.

Yasuda and Kawasaki established the Third National Bank in 1876, and then the Yasudas set up their own Yasuda Bank in 1880. Although the Yasuda Bank's investors consisted of several members of the Yasuda family, it seems likely that Zenjiro provided all its initial $¥ 200,000$ capitalization. Zenjiro needed several family members to satisfy the Meiji government's dictate that no single investor establish a bank.

In 1887 Zenjiro capitalized his family company, Hozensha, with an initial one million yen, designated as the paid-in capital of the Yasuda Bank. Zenjiro assigned half to Hozansha and the other half to ten of his relatives: six Yasuda families given $¥ 360,000$, two branch clans given $¥ 80,000$, and two other relations given $¥ 60,000$. Hozensha’s $¥ 500,000$ of stocks were designated the common property of the six Yasuda families. The charter Zenjiro established forbade the transfer of Yasuda Bank, even within the family. No certificates were issued, and ownership was recorded in a registration book in Hozensha's safe. Yasuda Bank shareholders also relinquished the right to embark on commercial activities of their own.

After observing the 1909 reorganization of the Mitsui group as a general partnership, Yasuda reorganized Hozensha similarly in 1912. The partnership served as a holding company for Yasuda securities, properties, and business operations. By this time, the Yasuda zaibatsu already contained seventeen banks and sixteen other business operations. New biological and adopted sons boosted the number of Yasuda family investors from ten to thirteen. In 1919 the Yasuda group established its house constitution, freezing the number of Yasuda investors at thirteen. The Yasuda zaibatsu remained focused on financial businesses. By not expanding into capitalhungry heavy industries as aggressively as the other great zaibatsu, the Yasuda group limited public shareholders' participation. ${ }^{25}$ Table 7.5, which summarizes the industrial diversification of the ten major prewar zaibatsu, illustrates this focus.

The Yasuda focus on banking was narrowed by the folding of eleven Yasuda-controlled banks into the Yasuda Bank in 1913. The new bank was the greatest of all the zaibatsu banks, with a 1913 paid-in capital of $¥ 150$ million—compared to $¥ 600$ thousand, $¥ 500$ thousand, $¥ 430$ thousand, and $¥ 300$ thousand for the Mitsui, Sumitomo, Daiichi, and Mitsubishi banks, respectively. The Yasuda Bank continued expanding via mergers with other banks, and rapidly developed strong relationships with the smaller

25. A reorganization as a joint-stock company was discussed during World War II but never implemented. 
Industrial diversification of the ten major zaibatsu in 1945, in millions of yen

\begin{tabular}{|c|c|c|c|c|c|c|}
\hline \multirow[b]{2}{*}{ Zaibatsu } & \multicolumn{4}{|c|}{ Industry } & \multirow[b]{2}{*}{$\begin{array}{l}\text { Zaibatsu } \\
\text { Total }\end{array}$} & \multirow[b]{2}{*}{$\begin{array}{c}\text { Zaibatsu } \\
\text { (\% of economy) }\end{array}$} \\
\hline & Finance & $\begin{array}{l}\text { Heavy } \\
\text { industry }\end{array}$ & $\begin{array}{l}\text { Light } \\
\text { industry }\end{array}$ & Other & & \\
\hline Mitsui & 169 & 2,214 & 274 & 404 & 3,061 & 9.4 \\
\hline Mitsubishi & 160 & 1,866 & 73 & 605 & 2,704 & 8.3 \\
\hline Sumitomo & 65 & 1,469 & 29 & 102 & 1,667 & 5.2 \\
\hline Yasuda & 209 & 119 & 117 & 64 & 510 & 1.6 \\
\hline Nissan (Aikawa) & 5 & 1,558 & 103 & 38 & 1,703 & 5.3 \\
\hline Asano & 0 & 419 & 89 & 76 & 594 & 1.8 \\
\hline Furukawa & 4 & 479 & 3 & 4 & 490 & 1.5 \\
\hline Okura & 6 & 218 & 34 & 56 & 314 & 1.0 \\
\hline Nakajima & 0 & 188 & 24 & 0.768 & 213 & 0.6 \\
\hline Nomura & 26 & 50 & 27 & 62 & 165 & 0.5 \\
\hline Top ten zaibatsu total & 644 & 8,582 & 773 & 1,412 & 11,420 & 35.0 \\
\hline Economy total & 1,215 & 17,513 & 4,600 & 9,108 & 32,437 & 100.0 \\
\hline $\begin{array}{l}\text { Top ten zaibatsu } \\
\text { (\% of economy) }\end{array}$ & 53 & 49 & 17 & 16 & 35 & \\
\hline
\end{tabular}

Source: Holding Company Liquidation Committee (HCLC), Japanese zaibatsu and Its Dissolution, as cited in Yasuoka (1976, pp. 34-35).

Azano and Mori zaibatsu. These ties gave the Yasuda Bank an industrially diversified loan portfolio, but the Yasuda core businesses remained financial-encompassing banking, insurance, and other financial services. As table 7.5 shows, the house of Yasuda limited its entry into heavy industries even during World War II.

The Mitsubishi zaibatsu began as Tsukumo Co. and was renamed Mitsukawa Company in 1872 because it had three (mittsu) ownersS. Ishikawa (1828-82), S. Kawada (1836-96), and K. Nakagawa. ${ }^{26}$ In 1873 Mitsukawa Co. was renamed Mitsubishi Co., which appears to have been a limited partnership between the three original owners and Yataro Iwasaki (1834-85). After Yataro's death, his son Hisaya (1865-1955) and Hisaya's younger brother Yanosuke (1851-1904) joined the partnership. The Mitsubishi partnership was dissolved around 1891, and Hisaya and Yanosuke Iwasaki each invested $¥ 250$ million in 1893 to set up a new limited partnership —also called the Mitsubishi Company.

The Mitsubishi Company's direct subsidiaries included Mitsubishi Shipbuilding and Mitsubishi Mining, which both extensively developed the privatized state-owned enterprises the zaibatsu purchased. Unlike the Mitsui, Sumitomo, and Yasuda charters, the Mitsubishi charter allowed sue among Japanese historians; see Mishima (1981). 
each Iwasaki clan to retain its income and start up its own businesses. This flexibility let individual Iwasaki clans enthusiastically capture business opportunities that the Mitsubishi Company itself could not. For example, Horaisha bought the privatized Takashima Coal Mine, whose continuing government subsidies prevented direct Mitsubishi ownership. ${ }^{27}$ Other important de facto Mitsubishi firms, like Asahi Glass, Meiji Life Insurance, and Kirin Beer, were de jure separate from the Mitsubishi zaibatsu. This was clearly a bureaucratic slight of hand, for these companies had extensive financing and other relationships with formal members of the Mitsubishi zaibatsu and were controlled by the Iwasaki family. These firms also all became Mitsubishi keiretsu companies after World War II.

Mitsubishi Company, the pyramid's apex, was reorganized as a jointstock company in 1937, and shares were distributed to Iwasaki relatives and seven unrelated executives, all of whom were forbidden to transfer their shares without permission from the company. In 1940 the company raised its paid-in capital from $¥ 120$ million to $¥ 240$ million, and the original two Iwasaki families together retained a 47.5 percent stake.

Although Mitsubishi, like Mitsui and Sumitomo, remained family controlled, the Iwasaki used marriage extensively to bring talented men into the family. Thus, unusually in a family enterprise, marriageable daughters were valued as highly as sons, if not more highly (Morikawa 1992, p. 53).

Mitsubishi Company's stakes in direct subsidiaries, like the Mitsubishi Bank and Mitsubishi Corporation, were small, averaging around 30 percent, versus 66 percent for Mitsui. Similarly, Mitsubishi's average ownership in direct subsidiaries of direct subsidiaries was only 18 percent, versus 9 percent for Mitsui. The Mitsubishi zaibatsu was less averse to issuing public equity, and so expanded further into capital-intensive industries like machinery, mining, finance, and shipping. This made Mitsubishi firms market leaders in these rising sectors, yet the Iwasakis retained full control, for their stakes were always sufficient to dominate shareholder meetings. ${ }^{28}$

Figure 7.5 illustrates the structure of the Mitsubishi zaibatsu as it later developed.

\subsubsection{Industrial Zaibatsu}

The Mitsui, Sumitomo, Mitsubishi, and Yasuda zaibatsu are generally ranked as the major family-controlled pyramidal groups of prewar Japan. Three other zaibatsu were also important, but their influence extended along specific product chains and did not include banks or financial firms.

These so-called industrial zaibatsu included the Asano group, built by Soichiro Asano (1848-1930) around the Asano Cement Company; the

27. The Iwasaki family was only allowed to purchase it from Horaisha when Takashima experienced financial distress. See Yasuoka (1976, p. 64) for details.

28. For details, see Mishima (1981, pp. 340-41). 


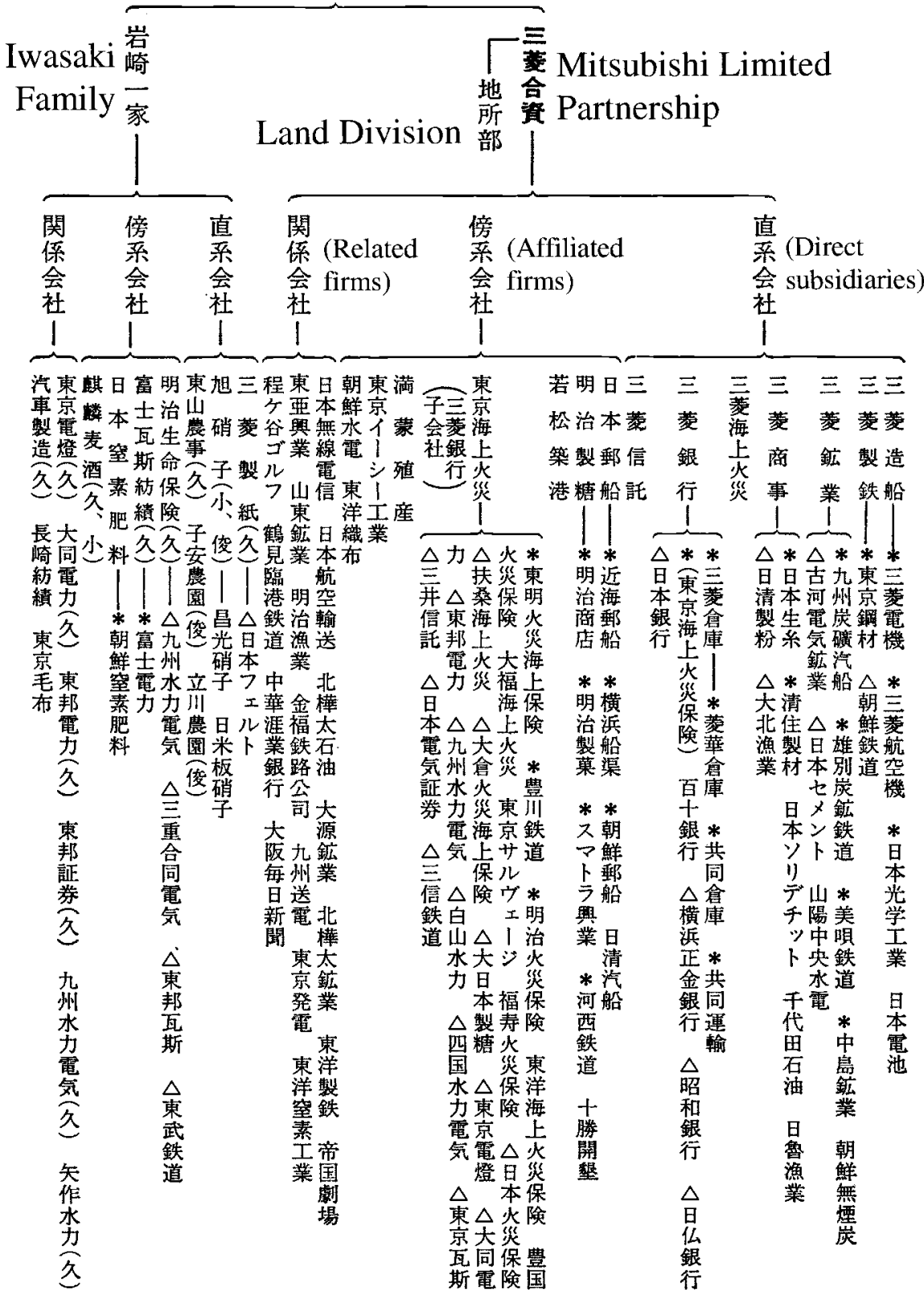

Fig. 7.5 Record of the structure of the Mitsubishi zaibatsu in 1930

Source: Takahashi (1930b, pp. 108-9).

Notes: Mitsubishi Limited Partnership's first-tier direct subsidiaries were Mitsubishi Shipbuilding, Mitsubishi Steel, Mitsubishi Mining, Mitsubishi Corporation, Mitsubishi Marine and Fire Insurance, Mitsubishi Bank, and Mitsubishi Trust Bank. Mitsubishi Limited Partnership owned and controlled fully its first-tier direct subsidiaries but did not necessarily fully control or own affiliated or related firms. More specifically, Mitsubishi Limited Partnership controlled the firms with asterisks fully and the firms with no asterisks or triangles predominantly but not fully. Mitsubishi Limited Partnership's control was weakest over the firms with triangles. The same ownership and control relationships apply to the firms under the Iwasaki family's control. 
Kawasaki group, built around Kawasaki Shipbuilding Co. by Shozo Kawasaki (1837-1911); and the Furukawa group, built by Ichibei Furukawa (1832-1903) around his Ashio Copper Mines Co.

\subsubsection{Widely Held Zaibatsu}

In addition to the four major family zaibatsu and the three industrial zaibatsu, five other pyramidal groups emerged in the early 1900s-Nissan, Nichitsu, Mori, Nisso, and Riken. These structures grew with the stock market, which became much more active in the 1900s. Share prices rose rapidly from 1917 to 1919 , and individual investors, like landlords and other property owners, bought increasingly into equity (Hashimoto 1997, p. 101). This augmented flow of capital into the market allowed, and perhaps arose from, the construction of pyramids financed with public equity throughout.

While the Mitsui, Mitsubishi, and Sumitomo apex firms were family owned, these new widely held zaibatsu had widely held apex firms. Although their founders often held quite small equity stakes in the apex firms, they had little fear of losing control because they were usually highly skilled engineers, whose expertise was essential to critical company operations. The chemistry experts Shitagu Noguchi, Tomonori Nakano, and Nobuteru Mori built the new Nichitsu, Nisso, and Mori zaibatsu, respectively. Masatoshi Okochi, an expert in machinery manufacture, built the new Riken zaibatsu, and the all-around genius Yoshisuke Aikawa built Nissan into a large, diversified zaibatsu, although machinery remained its most important business.

This technical expertise factor kept these new zaibatsu focused on heavy industry, chemicals, and electric power. However, as they grew, they also diversified to compete directly with family zaibatsu. Widely held zaibatsu, like industrial zaibatsu, did not control financial institutions and relied heavily on outside finance.

The development of the widely held zaibatsu can best be illustrated by the history of the largest such group-Nissan. The Nissan group was founded by Yoshisuke Aikawa (1880-1967) in a rather roundabout way.

By 1919, Aikawa's brother-in-law, Husanosuke Kuhara (1869-1965), had acquired 30 percent of Japan's domestic copper mines, 40 percent of its gold mines, and 50 percent of its silver mines. He accomplished this by floating $¥ 2.4$ million in an initial public offering of his Kuhara Mining Company. After the First World War, Japan experienced a series of depressions, and Kuhara Mining was badly hurt. When its subsidiary, Kuhara Trading, failed, Kuhara was forced to retire on a sick leave. He delegated the rebuilding of his company to his brother-in-law, Yoshisuke Aikawa, whose own much smaller firm, Tobata Cast Iron, had survived the depressions. Aikawa was an engineer and had studied state-of-the-art iron 
Kuhara Mining Company: The composition of shareholders, 1918-27

\begin{tabular}{lccc}
\hline & June 1918 & June 1920 & May 1927 \\
\hline Total number of outstanding shares & $1,500,000$ & $1,500,000$ & $1,500,000$ \\
Total number of shareholders & 9,761 & 13,842 & 14,858 \\
Average number of shares held per shareholder & 153.7 & 108.0 & 100.9 \\
Shareholders with 5,000 or more shares & & & \\
$\quad$ Total number of shareholders & 31 & 20 & 18 \\
$\quad$ Share ownership (\%) & 67.3 & 51.4 & 44.3 \\
$\quad$ Average number of shares held per shareholder & $32,566.5$ & $38,550.0$ & $36,916.7$ \\
Shareholders with fewer than 500 shares & & & \\
$\quad$ Total number of shareholders & 9,544 & 13,649 & 14,739 \\
$\quad$ Share ownership (\%) & 28.5 & 35.8 & 39.6 \\
$\quad$ Average number of shares held per shareholder & 44.7 & 40.0 & 40.3 \\
Kuhara family and relatives (\%) & 45.6 & 45.1 & 37.3 \\
\hline
\end{tabular}

Source: Udagawa (1976).

casting in the United States. To save Kuhara Mining, he pooled his own money with funds from relatives, managers, and outsiders to inject more than $¥ 25$ million into the company. ${ }^{29}$

Having dealt successfully with Kuhara Mining's debt crisis, Aikawa joined its board in 1926 and quickly replaced Kuhara as president. To put the firm on a solid long-term financial course, Aikawa needed to raise more capital without losing control. In December 1928 he listed a new holding company, Nippon Sangyo (Nissan). Simultaneously he also organized Nippon Mining, into which he merged Kuhara Mining. Since table 7.6 shows that Kuhara Mining had many public shareholders, this merger left Nippon Mining publicly held but controlled through a majority stake by Nissan.

Aikawa understood that Nissan, or any other new zaibatsu, would need substantial capital very quickly to achieve economies of scale comparable to those of the existing zaibatsu. The funds needed were far beyond his family assets, so bringing public shareholders in was unavoidable. Aikawa clearly understood the efficacy of pyramidal groups for tapping unlimited outside capital while retaining full corporate governance control. Figure 7.6 is Aikawa's (1934) vision of how a pyramid of listed subsidiaries, subsidiaries of subsidiaries, and so on, can put an unlimited amount of public stockholders' capital under his control.

Aikawa (1934) recognized that, since the apex firm of his pyramid was widely held, it was his responsibility to make sure the company always

29. He was widely expected to fail. Kuhara was compared at the time to Suzuki, described below. That Kuhara ultimately prospered and formed the basis of a new zaibatsu, while Suzuki failed and brought down an entire zaibatsu, greatly enhanced Aikawa's standing. 


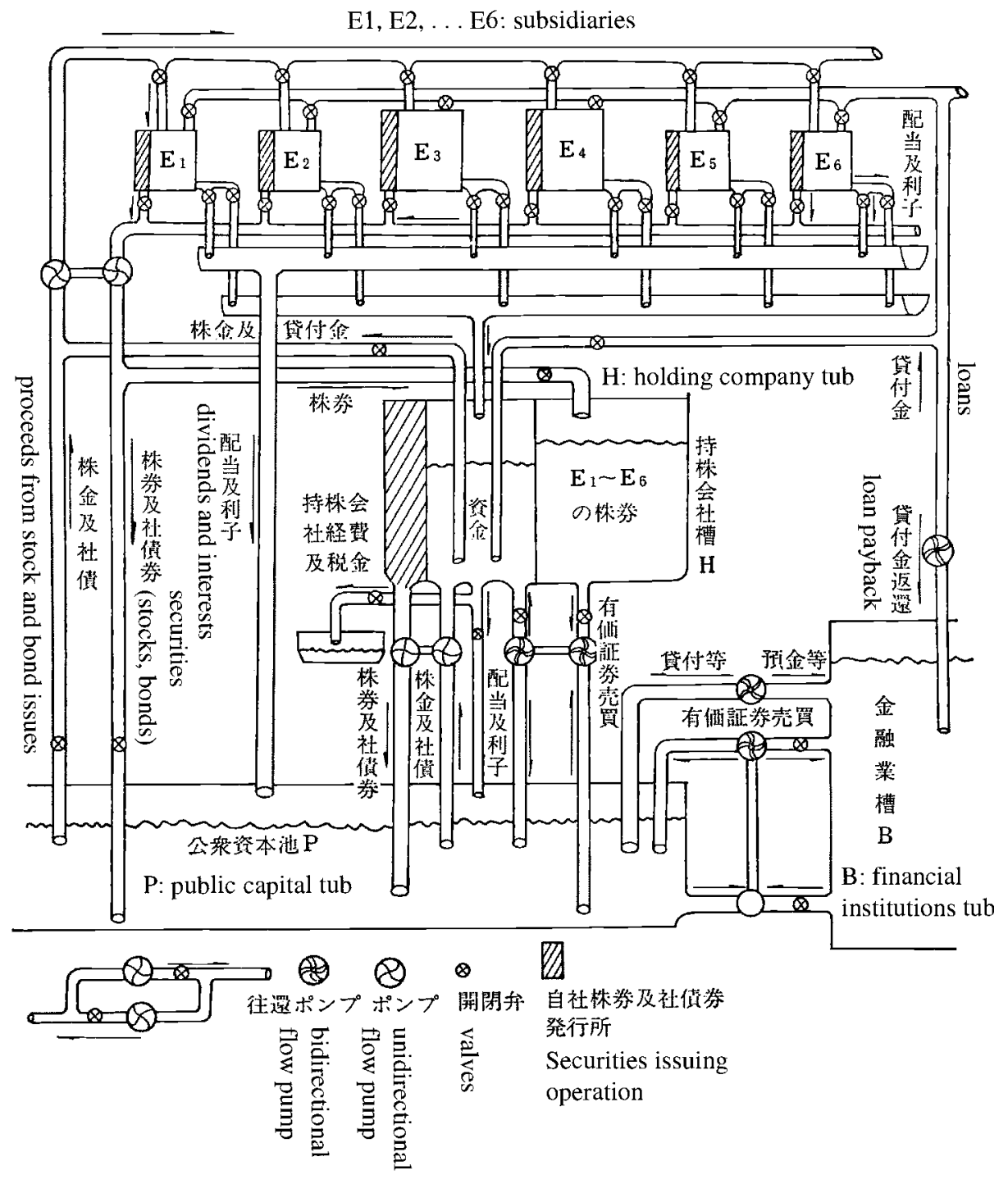

Fig. 7.6 Aikawa's vision for using capital markets to finance Nippon Sangyo (Nissan)

Source: Aikawa (1934).

Notes: Unidirectional flow pumps set the one-way flows of funds corresponding to, for example, payments of interest and dividends, and the proceeds from new issues of securities such as bonds and shares. Bidirectional flow pumps set the two-way flows of funds corresponding to, for example, the proceeds from and the repayments of loans, and the purchasing and selling transactions of securities. Aikawa's vision was that a holding company $(\mathrm{H})$ and its subsidiary firms (E1, E2, . ., E6) could grow using primarily public capital (P) and financial institutions (B) while enriching the capital base of the holding company, represented by $\mathrm{B}$, the holding company tub. 
made acceptable profits and that its shareholders received a stable payment of dividends. ${ }^{30}$ Some 70 percent of Nissan's assets were shares in Nippon Mining, so Nissan was still dangerously exposed to that sector, which remained chronically weak until the Japanese government began accumulating gold in 1932. Using this business upturn, Aikawa sold Nippon Mining shares and used the funds raised to diversify Nissan's holdings extensively.

Aikawa's main strategy was to purchase promising firms, develop them as fully owned subsidiaries, and then take them public through initial public offerings (IPOs). In creating these spin-offs, or bunshin kaisha, Nissan's role in Japan's development resembled that of the 1990s venture capital firms in the United States (see, e.g., Gompers and Lerner 2002). However, while venture capitalists seek to sell their start-ups completely to the public to raise funds for the next venture, Nissan always retained a control block, using further IPOs to extend the pyramid. This appears to reflect Aikawa's desire to retain a final say in important decisions.

Nissan's partially spun-off subsidiaries usually prospered, further enriching both Nissan's shareholders and their own. Subsidiaries acquired or spun off their own subsidiaries, and the pyramidal structure expanded. Nissan’s own paid-in capital increased from $¥ 5.25$ million in 1933 to $¥ 198.37$ million in 1937 . During the same period, its total assets increased from $¥ 91.08$ million to $¥ 383.10$ million, and its securities held increased from $¥ 53.38$ million to $¥ 269.92$ million. Table 7.6 shows Nissan’s share price for the period 1930-37.

All the while, Nissan itself became ever more widely held. By May 1937, Nissan had 51,804 shareholders, 50,783 of whom owned fewer than 500 shares. The fraction of shares Aikawa and his relatives held continued to fall - from 19.2 percent in 1929 to only 4.5 percent in 1937 . By 1937 , only four shareholders, including Aikawa, held more than 10,000 Nissan shares.

By this time, table 7.7 shows Nissan at the apex of a pyramid exceeded in scale only by the Mitsui and Mitsubishi groups. The Nissan group now included Nippon Mining, Hitachi Ltd., Hitachi Power, Nissan Motor, and many other large manufacturers and utilities. ${ }^{31}$

30. However, Aikawa (1934) also justifies "management nationalism" as a legitimate reason for having invested in "a few new business lines" that he thought were promising for the future but would currently generate no returns in the near term.

31. Unlike Mitsui and Mitsubishi, which kept full family control of their holding companies (first as partnerships and then as joint stock companies) until the end of World War II, Nissan's equity ownership was more widely held and became more so toward World War II. Nevertheless, Yoshisuke Aikawa and his relatives managed to keep the Nissan pyramid under their full control all the way through the end of World War II. Judging from his survey on budgeting practices of many Japanese firms in the 1930s, Hasegawa (1938) concludes that Nissan as a holding company uses the budgeting process of its more than thirty surveyed subsidiaries in various industries in a centralized totalitarian way. 
Table 7.7

Rankings of the top zaibatsu as of midyear 1937 by number of firms and paid-in capital

\begin{tabular}{lcc}
\hline Zaibatsu & Number of group firms & Total paid-in capital \\
\hline 1. Mitsui & 101 & $¥ 1,177,200,000$ \\
2. Mitsubishi & 73 & $¥ 848,204,000$ \\
3. Nissan & 77 & $¥ 473,632,000$ \\
4. Sumitomo & 34 & $¥ 383,800,000$ \\
5. Yasuda & 44 & $¥ 263,866,000$ \\
6. Asano & 50 & $¥ 236,261,000$ \\
7. Nichitsu & 26 & $¥ 197,100,000$ \\
8. Mori & 20 & $¥ 141,996,000$ \\
9. Okura & 51 & $¥ 133,845,000$ \\
10. Furukawa & 19 & $¥ 101,994,000$ \\
\hline
\end{tabular}

Source: Yasuoka (1976).

\subsubsection{Local Zaibatsu}

There were many locally important business families in Japan at this time, whose operations were limited to specific geographical areas (e.g., prefectures) and usually also specific lines of business. These families accumulated wealth in closely held family firms and then used this wealth to expand into new businesses, sometimes bringing in other local investors. Mostly, these pyramidal structures remained small, but a few acquired national scope - though they kept their head offices in the original localities. In general, these local zaibatsu did not develop into highly industrialized operations. It is possible that their limited access to capital explains this. Indeed, their dominance in certain regions may explain why industrialization favored some regions over others.

The role of local zaibatsu in regional development remains poorly understood. Important local zaibatsu include the Nakano group (based in Niigata), the Itaya group of Hokkaido, the Ito group based in Nagoya, another Ito group in Hyogo, the Yasukawa group of Fukuoka, the Kaishima group of Fukuoka, and the Katakura of Nagano. Figure 7.7 describes some of these groups.

\section{Fig. 7.7 (facing page) Representative local zaibatsu families}

Source: Morikawa (1976).

Notes: There were many family-based zaibatsu groups in many localities in Japan before World War II. The scale of their business operations and geographic coverage was much smaller than that of the major zaibatsu groups such as Mitsui, Sumitomo, and Mitsubishi. Nevertheless, these local zaibatsu groups often organized their companies in pyramidal structures as the major zaibatsu groups did. Some of these local zaibatsu companies survived World War II and still exist today. For example, Kikkoman (Mogi zaibatsu in Chiba), Matsuzakaya Department Store (Ito zaibatsu in Nagoya), Kurashiki Textile (Ohara zaibatsu in Okayama), and Yasukawa Electric (Yasukawa zaibatsu in Fukuoka) are shown here. 


\begin{tabular}{|c|c|c|c|c|c|}
\hline Name & Location & $\begin{array}{l}\text { Holding Co. } \\
\text { (capital in } \\
10,000 \text { yen) }\end{array}$ & Familiy members/relatives & Business & $\begin{array}{l}\text { Where they } \\
\text { invested }\end{array}$ \\
\hline $\begin{array}{l}\text { 地方資産家 } \\
\text { (代表名) }\end{array}$ & 住所 & $\begin{array}{l}\text { 本社 } \\
\text { (資本金) }\end{array}$ & 家族 $\cdot$ 同族 & 家業 & 投資先 \\
\hline 板谷 宮吉 & 北海道小樽 & & 宮吉、順助(宮吉養子) & $\begin{array}{l}\text { 醸造 } \\
\text { 雑乘肥料問屋 } \\
\text { 板谷商船 } \\
\text { 北門貯蓄銀行 }\end{array}$ & $\begin{array}{l}\text { 南洋郵船 } \\
\text { 北海水力電気 } \\
\text { 洞私湖電鉄 } \\
\text { 樺太銀行 }\end{array}$ \\
\hline 相馬 哲平 & 北海道函館 & $\begin{array}{l}\text { 相馬合名 (400 } \\
\text { 万円) }\end{array}$ & $\begin{array}{l}\text { 哲平、慳弥(同長男)、市作 } \\
\text { (同長女の夫)、省三(同次 } \\
\text { 男)、康平 (同次女の子) }\end{array}$ & $\begin{array}{l}\text { 相馬商店 (株) } \\
\text { (問屋、金融、漁 } \\
\text { 業、鉱業) } \\
\text { 相馬銀行 }\end{array}$ & $\begin{array}{l}\text { 百十三銀行 } \\
\text { 画館貯蓄銀行 }\end{array}$ \\
\hline 茂木 七左衛門 & 千葉野由 & 千秋社 (名) & $\begin{array}{l}\text { 七左衛門，高梨兵左衛門 } \\
\text { (七左衛門の妹の夫) }\end{array}$ & 罾油醮造 & $\begin{array}{l}\text { 野田桨油 } \\
\text { 野田商誘銀行 } \\
\text { 野田運輸 }\end{array}$ \\
\hline $\begin{array}{l}\text { 中野 忠太郎 } \\
\text { (寛一長男) }\end{array}$ & 新潟金津 & $\begin{array}{l}\text { 中野興業 }(2,5 \\
\text { OO万円 })\end{array}$ & $\begin{array}{l}\text { 忠太郎、信吾(寛一次男)、孝 } \\
\text { 次(忠太郎次男)、冬松 (寛一 } \\
\text { 次女の夫) }\end{array}$ & $\begin{array}{l}\text { 空野興業 (原油採 } \\
\text { 掘販壳) } \\
\text { 中野殖産興業 }\end{array}$ & $\begin{array}{l}\text { 日本石油 } \\
\text { 新潟港湾倉庫 } \\
\text { 蒲原鉄道 }\end{array}$ \\
\hline 西脇 済三郎 & 新旊小千谷 & 西脇合名 & $\begin{array}{l}\text { 三郎，健次(同弟)、新次郎 } \\
\text { (同姉の夫) }\end{array}$ & $\begin{array}{l}\text { 西脇銀行 } \\
\text { 西脇商店 }\end{array}$ & $\begin{array}{l}\text { 小千谷銀行 } \\
\text { 北越水力電気 } \\
\text { 三光紡䋶 } \\
\end{array}$ \\
\hline $\begin{array}{l}\text { 片倉 謙太郎 } \\
\text { (三代目) }\end{array}$ & 長野諏訪 & 片倉合名 & $\begin{array}{l}\text { 兼太郎(二代長男·初代娚)， } \\
\text { 勝衛(初代いとこの長男)、武 } \\
\text { 雄(初代長男)、今开五介(初 } \\
\text { 代弟)等2 1名 }\end{array}$ & $\begin{array}{l}\text { 片含製柰 } \\
\text { 日東紡績 } \\
\text { 片含生命 } \\
\text { 片會殖産 } \\
\text { 片含米穀肥料 }\end{array}$ & $\begin{array}{l}\text { 信州電文 } \\
\text { 昭和絹靴下 }\end{array}$ \\
\hline $\begin{array}{l}\text { 銅木 与平 } \\
\text { (六代目) }\end{array}$ & 静岡清水 & & & 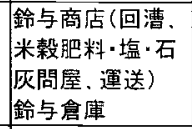 & \begin{tabular}{|l} 
清水銀行 \\
三十五銀行 \\
清水運送 \\
清水食品
\end{tabular} \\
\hline 中埜 半左衛門 & 愛知半田 & & $\begin{array}{l}\text { 半左衛門. 又左衛門. 半六. } \\
\text { 良吉、盛田善平 }\end{array}$ & $\begin{array}{l}\text { 中埜酢店 } \\
\text { 中埜踷油店 } \\
\text { 中埜酒店 } \\
\text { 中埜銀行 } \\
\text { 中埜貯䓊銀行 } \\
\text { 半田倉庫 } \\
\text { 敷岛屋製粉所 }\end{array}$ & $\begin{array}{l}\text { 日本麦酒銝泉 } \\
\text { 知多鉄道 }\end{array}$ \\
\hline 伊藤 次郎左衛門 & 名古屋 & \begin{tabular}{|l} 
伊藤総本店 \\
伊藤産業合名 \\
$(1,000$ 万円 $)$
\end{tabular} & $\begin{array}{l}\text { 次郎左衛門、松之助(同長 } \\
\text { 男)、銃次郎(同次男)、鈴三 } \\
\text { 郎(同三男) }\end{array}$ & $\begin{array}{l}\text { 松坂屋 } \\
\text { 伊藤銀行 } \\
\text { 山東煙草 } \\
\text { 山東窯業 } \\
\text { 三綿商店 }\end{array}$ & \begin{tabular}{|l}
$\mid$ 愛知銀行 \\
日本貯蓄銀行 \\
中央信託 \\
名古屋製陶 \\
賞知時計電機
\end{tabular} \\
\hline 辰馬 吉左衛門 & 兵庫西宮 & & 吉左衛門 & $\begin{array}{l}\text { 辰馬本家酒造 } \\
\text { (白鹿醸造元) } \\
\text { 辰馬汽船 } \\
\text { 辰馬海上火災保 } \\
\text { 険 } \\
\text { 夙川土地 }\end{array}$ & $\begin{array}{l}\text { 三十四銀行 } \\
\text { 神戸互斯 } \\
\text { 神戸海上運送火 } \\
\text { 災保険 } \\
\text { 兵庫大岡信託 }\end{array}$ \\
\hline 八馬 謙介 & 兵厦西宮 & $\begin{array}{l}\text { 多聞合資 (200 } \\
\text { 万円) }\end{array}$ & $\begin{array}{l}\text { 謙介、安二郎(同弟)、駒雄 } \\
\text { (同上) }\end{array}$ & $\begin{array}{l}\text { 西宮酒造 } \\
\text { 多閪與業 } \\
\text { 八馬汽船 }\end{array}$ & \begin{tabular}{|l} 
武庫銀行 \\
西宮銀行 \\
神戸海上運送火 \\
災保険 \\
兵庫大岡信託
\end{tabular} \\
\hline
\end{tabular}




\begin{tabular}{|c|c|c|c|c|c|}
\hline Name & Location & $\begin{array}{l}\text { Holding Co. } \\
\text { (capital in } \\
10,000 \text { yen) }\end{array}$ & Familiy members/relatives & Business & $\begin{array}{l}\text { Where they } \\
\text { invested }\end{array}$ \\
\hline $\begin{array}{l}\text { 地方資産家 } \\
\text { (代表名) } \\
\end{array}$ & 住所 & $\begin{array}{l}\text { 本社 } \\
\text { (資本金) }\end{array}$ & 家族·同族 & 家業 & 投資先 \\
\hline 伊藤 長次郎 & 兵庫印南 & $\begin{array}{l}\text { 静得社(資) (1 } \\
70 \text { 万円) }\end{array}$ & $\begin{array}{l}\text { 長次郎、熊三(同長男)、勇次 } \\
\text { 郎 }\end{array}$ & $\begin{array}{l}\text { 酒造業 } \\
\text { 伊藤土地合名 }\end{array}$ & \begin{tabular}{|l} 
三十八銀行 \\
神栄生系 \\
昭和毛糸紡績 \\
山陽中央水電
\end{tabular} \\
\hline 大原 孫三郎 & 岡山會敷 & & 孫三郎 & \begin{tabular}{|l} 
倉敷紡續 \\
軮敷紡織
\end{tabular} & $\begin{array}{l}\text { 中国銀行 } \\
\text { 岡山合同貯蓄銀 } \\
\text { 行 } \\
\text { 中国信託 }\end{array}$ \\
\hline 安川 敬一郎 & 福岡户畑 & 安川松本合名 & $\begin{array}{l}\text { 敬一郎、松本健次郎(敬一郎 } \\
\text { 次男)、安川清三郎(同三 } \\
\text { 男)、安川兼五郎(同五男) }\end{array}$ & $\begin{array}{l}\text { 明治鈸業 } \\
\text { 九州製鋼 } \\
\text { 明治紡績 } \\
\text { 安川電機 } \\
\text { 黑崎嗐業 }\end{array}$ & $\begin{array}{l}\text { 若松築港 } \\
\text { 嘉穂鉱業 }\end{array}$ \\
\hline 貝島 太市 & 福岡直方 & $\begin{array}{l}\text { (貝島合名 } \\
\text { O00万円) }\end{array}$ & $\begin{array}{l}\text { 太市 (太助三男)、栄一(太助 } \\
\text { 孫·宗家)、健次(栄一叔 } \\
\text { 父)、栄四郎(栄一叔父) }\end{array}$ & \begin{tabular}{|l} 
貝島鈸業 \\
貝島商事 \\
貣島乾溜 \\
貝島木材防噟
\end{tabular} & $\begin{array}{l}\text { 中央火災賃害 } \\
\text { 若松築港 }\end{array}$ \\
\hline 麻生 太吉 & 福岡飯塚 & & $\begin{array}{l}\text { 太吉、太七(同弟)、義之介 } \\
\text { (同蚨子) }\end{array}$ & \begin{tabular}{|l} 
麻生商店 \\
嘉穗銀行 \\
嘉穗賍蓄銀行 \\
嘉穂電燈 \\
\end{tabular} & $\begin{array}{l}\text { 九州水力電気 } \\
\text { 若松築港 } \\
\text { 幸袋工作所 }\end{array}$ \\
\hline
\end{tabular}

Fig. 7.7 (cont.)

\subsubsection{The Zaibatsu and Independent Companies}

Numerous independent entrepreneurs also shaped the economy in this era. Sakichi Toyoda patented the Toyoda wooden hand loom in 1891 and an innovative automatic loom in 1924. ${ }^{32}$ Platt Brothers and Co. of England, a world leader in looms, paid the 1929 equivalent of one million yen for the rights, and Toyoda later used these funds to found Toyota Motors. Another important entrepreneur, Konosuke Matsushita, founded Matsushita Electric Industries in Osaka in 1918 and developed it into one of the world's largest electronics manufacturers. Many of these new ventures were affiliated with established zaibatsu to varying degrees.

Toyota was loosely affiliated with the Mitsui zaibatsu until the end of World War II and the Mitsui keiretsu after the war. ${ }^{33}$ In 1898, Mitsui Bussan agreed to market Toyoda's products. When Toyoda set up his own textiles firm, Toyoda Shokai, Mitsui Bussan provided capital. When he established Toyoda Style Textile Machines, a predecessor to Toyoda Boshokuki,

32. During his lifetime Sakichi Toyoda made 119 inventions, of which 13 were awarded U.S. and other foreign patents.

33. As of 1930, figure 7.3 lists Toyoda Boshokuki (Toyoda Textile Machines) and another Toyoda company as controlled by Toyo Menka Trading Firm, which was owned by Mitsui Bussan. 
in 1906, Mitsui Bussan again provided capital. The Toyoda and Mitsui continued to have close business and family ties. For example, Sakichi Toyoda adopted his son-in-law, Risaburo Toyoda (formerly Risaburo Kogama), the second son of the Kogama family, which ran Mitsui's Toyo Menka. Risaburo subsequently became the first president of Toyota Motor. ${ }^{34}$

Matsushita did business with the Jugo Bank, but Sumitomo opened a branch near his factory in 1925 and approached him about doing business. Matsushita asked Sumitomo for a $¥ 20,000$ line of credit, an unusual arrangement at the time, and Sumitomo agreed. Although Matsushita had never used the line of credit, when Jugo Bank failed in a depression shortly thereafter, Sumitomo honored the agreement and extended credit. Matsushita accordingly began a long-term relationship with the Sumitomo Bank in 1927. Matsushita was never listed as a Sumitomo company, since the group has as its own electronics firm, NEC. However, its close relationship with the Sumitomo Bank continued for decades. Matsushita expanded, building its own pyramidal group, and was numbered among the great zaibatsu by the Allied forces charged with rebuilding Japan's postwar economy. Following World War II the Sumitomo Bank became the largest bank block holder of Matsushita shares and its main bank. At the end of World War II Matsushita was not formally owned by the Sumitomo family. Yet it was designated as a zaibatsu group by the Allied forces in June 1946, and Konosuke Matsushita and all other top executives with ranks above managing directors were purged from all public offices in November 1946. Konosuke Matsushita was apparently respected by the Matsushita employees, and the purge generated sympathy among Matsushita's labor unions. The union leaders presented 15,000 signatures from their members and families to the general headquarters of the Allied forces and the Japanese government. Because of this unusual support, Konosuke Matsushita's and other Matsushita executives' purge was downgraded and then was dropped entirely in May 1947. Matsushita companies were able to resume operation.

Table 7.5 shows zaibatsu firms owning about 35 percent of corporate assets in 1946, with the remainder held by independent firms. Many independent firms, like Toyota and Matsushita, were actually bound, more or less tightly, to an established zaibatsu. Many that would become important decades later were not key players in the prewar corporate sector. But zaibatsu firms' dominance of key industries like natural resources, chemicals, manufacturing, and trade, and of the associated distribution channels, was overwhelming by the start of World War II. Thus, despite their number and

34. Kiichiro Toyoda, Sakichi's son with his first wife, spent most of his life developing automobiles, but he got along poorly with Risaburo and died without taking charge of Toyota Motors. 
collective economic importance, independent firms were unquestionably less politically influential during this period.

\subsection{Ownership Changes during the Depressions}

In the 1920s and early 1930s, Japan endured a series of depressions, culminating in the Great Depression. The Great Kanto Earthquake of 1923 so disrupted the economy that the Roaring Twenties were essentially mute in Japan. Several major zaibatsu collapsed. Studying which zaibatsu failed and which survived is highly instructive.

Key factors explaining survival appear to be the existence of a bank in the zaibatsu, its position in the pyramid, and its role in the business dealings of the group. The Mitsubishi, Mitsui, and Sumitomo zaibatsu all had banks very near the apexes of their pyramids. Consequently, their banks' health was a primary concern of the controlling families. Moreover, any tunneling that occurred would tend to increase the assets and incomes of these banks.

The Mitsubishi, Mitsui, and Sumitomo banks also had well-diversified loan portfolios, with only 10 to 20 percent of outstanding loans to other firms in their own zaibatsu. ${ }^{35}$ Moreover, these banks held equity in many firms spanning many industries. Indeed, the reticence of the Mitsubishi Bank to lend to related companies during the depressions forced many, though not the mining and shipbuilding concerns, to issue public shares. The average stake of the Mitsubishi apex partnership in its first tier subsidiaries fell from 83.5 percent in 1921 to 69.0 percent in 1928.

Other zaibatsu families used their banks primarily to raise money for their zaibatsu firms. These so-called organ banks were thus poorly diversified. For example, 94 percent of the Nakazawa Bank's loans were to insiders, as were 75 percent of the Watanabe Bank's loans. Likewise, 75 percent of the loans held by the Matsukata zaibatsu's Jugo Bank were to Matsukata firms. Prior to their collapses in 1927, 72 percent of the loans of the Suzuki's captive bank, the Taiwan Bank, were to Suzuki companies.

\subsubsection{The Rise and Fall of the Suzuki Zaibatsu ${ }^{36}$}

The Suzuki family, like many other Tokugawa-era mercantile families, participated actively in Japan's foreign trade after the restoration. Even though they began as specialists in silk, copper, clothing, or sugar, they eventually required a general trading firm, or sogo shosha, to transact barter business domestically and to handle transactions with foreigners. A

35. Such diversification is clearly sound banking practice to reduce risk. This may have been the banks' deliberate objective, but this is not entirely clear.

36. Kato (1957) details the use and structure of organ banks, including that of the Suzuki group, and is the source of much of this section. See also Okazaki and Yokoyama (2001) for empirical evidence and a summary of other work. 
sogo shosha was a general entity that could deal with all types of profit opportunities in both domestic and foreign markets. The first and largest was Mitsui Bussan, which served as a model for many others. ${ }^{37}$

One imitator was Suzuki Shoten, the Suzuki Merchant Company. The Suzukis began as sugar traders and organized a sogo shosha to handle miscellaneous transactions related to that business. Suzuki Shoten quickly grew to become the second largest sogo shosha. Suzuki's rapid expansion took place in two stages.

The first was during Japan's intensive drive to develop its new colony in Taiwan, acquired during the Sino-Japanese War of 1894 to 1895. Taiwan's climate was ideal for sugar cane, and the Suzukis were the logical point men to handle Japanese investment in that industry. To transport sugar to Japan, the Suzukis needed ships, so it expanded into shipping and shipbuilding. At this point, the apex firm of the zaibatsu remained a single proprietorship run by the family patriarch, soon one of Japan's richest merchants.

The second stage occurred in the period immediately after World War I. During a sustained boom from 1914 to 1919, Japan's gross national product (GNP) grew fivefold, and the Suzuki zaibatsu expanded aggressively, proliferating new firms into many industries. In 1903, the apex firm became a general partnership capitalized at $¥ 500,000$. By 1920 , this had increased one hundredfold to $¥ 50$ million yen. Already in 1915, the Suzukis’ annual business in foreign trade reached $¥ 1.54$ billion, exceeding that of Mitsui Bussan. By the end of the boom, the Suzuki group looked comparable in many ways to the Mitsui and Mitsubishi zaibatsu.

One of the Suzukis' critical successes occurred in November 1914, three months after the beginning of the First World War. Although Japan was mired in a deep recession, Naokichi Kaneko (1868-1944), the manager of Suzuki Shoten, and Seiichi Takahata, the company's London branch manager, foresaw that German U-boats would raise ship and commodity prices sharply. Kaneko ordered Takahata to buy everything available, including raw materials aboard any transport ship. Suzuki's purchases of ships, iron, steel, sugar, wheat, and other commodities wrought an immediate profit of over $¥ 100$ million. This move, more than anything else, make Suzuki a global player in trade.

Takahata was also skillful in dealing with Great Britain and the other allied countries, procuring for them raw materials, iron and steel products, food supplies, ships, and the like. With 50,000 tons of ships sunk on an average day, Britain suffered a severe shortage of transport capacity, and was directly in the business of buying ships. At one point, the British government advanced Suzuki an unprecedented $£ 500,000$ deposit toward the purchase of ships. Suzuki was also flooded with orders for food from the

37. Others were organized by the Mitsubishi, Masuda, Abe, Mogi, Takada, Iwai, Ataka, and Yuasa groups. 
British and allied governments. Takahata responded, for example, by selling them entire cargos of beans, grain, and other food items from Hokkaido together with the ships themselves.

These developments caused Suzuki to enter a long-term relationship with the Taiwan Bank. Suzuki's foreign trade transactions were now so enormous that Japan's only government-authorized foreign exchange bank, Yokohama Shokin Bank, ${ }^{38}$ was incapable of handling them all, forcing Suzuki to rely on more expensive merchant bankers. ${ }^{39}$ The Japanese government had granted the Taiwan Bank special privileges to deal in foreign exchange, and Takahata seized upon this to unplug Suzuki's foreign exchange bottlenecks. The Taiwan Bank welcomed Suzuki's overtures because its extensive nonperforming loans in China had discouraged other zaibatsu companies from doing business with it.

A brief but severe recession followed the November 1918 armistice, and several small zaibatsu, including Mogi, Kuhara, Masuda, and Abe, failed. The Suzuki group survived, and when the economy recovered in September 1919, Takahata foresaw another boom. The pace of the Suzukis' global expansion was unprecedented. The Suzuki group gleaned huge profits in everything from Java sugar to wheat and soybeans from Siberia, Manchuria, and Qingdao. In one transaction, the Suzukis shipped 360,000 tons of wheat from Manchuria to Great Britain using 10,000 boxcars of the Manchurian Railway and forty-five 8,000- to 10,000-ton freighters. In 1919 and 1920, Takahata sold fifty shiploads of Java sugar and earned 65 million guilders on the 1920 transactions alone.

In 1923, Kaneko restructured the Suzuki pyramid, floating the trade division of Suzuki Shoten as the Suzuki Stock Company, or Kabushiki Suzuki, capitalized at $¥ 80$ million and with a paid-in capital of $¥ 50$ million. Suzuki Shoten's remaining operations were reorganized into a holding company, Suzuki General Partnership or Suzuki Gomei, capitalized at $¥ 50$ million. Suzuki General Partnership became the new apex firm, controlling seventy-eight listed firms. Of these, ten were in food industries, twentyfour in chemicals, four in textiles, two in tobacco, five in mining, five in iron and steel, three in electric machinery, three in electric power, three in railways, two in shipping, two in fishing, two in real estate and warehousing, three in development, two in the banking and trust business, four in insurance, and three in commerce.

The sixty-five of these that were integral parts of the Suzuki zaibatsu had a capitalization of $¥ 560$ million. The apex firm employed 3,000 people, and the pyramid firms had 25,000 employees in total. Figure 7.8 diagrams the Suzuki pyramid at its greatest extent.

38. Yokohama Shokin Bank became the Bank of Tokyo after World War II, which more recently merged with the Mitsubishi Bank to form the Bank of Tokyo-Mitsubishi.

39. The only other Japanese trading firm that had enough foreign business to warrant using merchant bankers was Mitsui Bussan. 


\begin{tabular}{|c|c|c|c|c|c|c|c|c|c|c|c|c|c|c|c|}
\hline & \multirow{2}{*}{$\begin{array}{l}\text { Company name } \\
\text { 会社(株) 別 }\end{array}$} & \multirow{2}{*}{\begin{tabular}{|l|} 
Paid-in \\
capital \\
(million yen) \\
資本金 (払 \\
远汃)
\end{tabular}} & \multirow{2}{*}{\begin{tabular}{|l|}
$\begin{array}{l}\text { Date of } \\
\text { establishment }\end{array}$ \\
設立年月
\end{tabular}} & \multirow{2}{*}{\begin{tabular}{|l|} 
Location \\
所在地
\end{tabular}} & \multicolumn{11}{|c|}{ Notes } \\
\hline & & & & & A & $B$ & $\mathrm{C}$ & $D$ & $\mathrm{E}$ & $F$ & G & $\mathrm{H}$ & I & J & K \\
\hline & 第六十五銀行 & $10(6.25)$ & 阴治 $11.11(1878)$ & 神户 & & $\bar{x}$ & & & & $\triangle$ & & & $\triangle$ & $\triangle$ & \\
\hline & 天満織物 & $7(5.243)$ & 20.3 & 大阪 & & $\mathrm{X}$ & 0 & 0 & 0 & $\triangle$ & & + & 0 & $\triangle$ & $\bar{x}$ \\
\hline 3 & 日本セメント & $5(5)$ & 21. 3 & 東京 & & & $\triangle$ & & $\triangle$ & & & + & $\triangle$ & & \\
\hline & 日本教育生命保険 & $0.3(0.075)$ & 29. $9(10)$ & 東京 & $\mathrm{O}$ & (0) & $\triangle$ & $\triangle$ & $\triangle$ & $\triangle$ & & + & $\triangle$ & $\triangle$ & (0) \\
\hline 5 & 日本製粉 & $12.3(12.3)$ & $29.10(9)$ & 東京 & & $x$ & 0 & 0 & $\mathrm{O}$ & $\triangle$ & & + & 0 & $\triangle$ & $x$ \\
\hline & 大日本塩業 & $4(3.802)$ & 36.9 & 東京 & 0 & (0) & 0 & 0 & 0 & $\triangle$ & & + & $\mathrm{O}$ & $\triangle$ & 6 \\
\hline & 神戸製鋼所 & $20(20)$ & $38.9(44.6)$ & 神戸 & $\mathrm{O}$ & $\theta$ & $\mathrm{O}$ & 0 & 0 & 0 & & 1 & 0 & 0 & 6 \\
\hline 8 & 東亜製粉 & $2.5(1.25)$ & 39.10 & 東京 & & $\mathrm{X}$ & & & & & & & & & \\
\hline 9 & 東重煙草 & $10(5.8)$ & $39.11(10)$ & 東京 & & $x$ & $\triangle$ & $\triangle$ & $\triangle$ & $\triangle$ & & + & $\triangle$ & $\triangle$ & \\
\hline 10 & 東京毛織 & $16(16)$ & 39.11 & 東京 & & $\square$ & $\triangle$ & $\triangle$ & $\triangle$ & $\triangle$ & & 1 & $\triangle$ & $\triangle$ & 7 \\
\hline 11 & 日本酒類醅造 & $5(2.15)$ & 39.12 & 大里 & $\mathrm{O}$ & & & & & & & & & & $(8)$ \\
\hline 12 & 東工業 & $0.5(0.5)$ & 40.1 & 大阪 & $\mathrm{O}$ & $\theta$ & 0 & $\triangle$ & 0 & 0 & & - & 0 & 0 & (6) \\
\hline 13 & 東洋製糖 & $36.25(22.03)$ & 40.2 & 台湾 & & $x$ & 0 & $\mathrm{O}$ & 0 & $\triangle$ & & + & $\triangle$ & $\triangle$ & $x$ \\
\hline 14 & 塩水港製糖 & $25(21.563)$ & $40.3(2)$ & 台湾 & & $x$ & $\triangle$ & $\triangle$ & & & & 1 & & $\triangle$ & \\
\hline 15 & 東洋海上火災保険 & $3(0.75)$ & 41.6 & 東京 & & & $\triangle$ & $\triangle$ & $\triangle$ & $\triangle$ & & + & $\triangle$ & & \\
\hline 16 & 日本商業 & $5(5)$ & 42.2 & 大阪 & 0 & $\theta$ & 0 & 0 & $\mathrm{O}$ & 0 & 0 & & 0 & $\mathrm{O}$ & $\mathbf{O}$ \\
\hline 17 & 帝国麦酒 & $10(5.5)$ & $45.5(6)$ & 大里 & & $\square$ & $\triangle$ & $\triangle$ & $\triangle$ & $\triangle$ & & + & $\triangle$ & $\triangle$ & $\exists$ \\
\hline 18 & 南満州物産 & 1(1) & 大正 2.1 & 大連 & 0 & 0 & 0 & 0 & & 0 & & & 0 & 0 & $\overrightarrow{0}$ \\
\hline 19 & 大正生命保險 & $0.5(0.125)$ & 2.4 & 東宗 & 0 & (O) & $\triangle$ & $\triangle$ & $\triangle$ & $\triangle$ & & + & $\triangle$ & $\triangle$ & (c) \\
\hline 20 & 宜蘭殖産 & $0.475(0.475)$ & 4. 3(4) & 台湾 & 0 & (O) & 0 & 0 & 0 & $\triangle$ & & - & $\Delta$ & $\triangle$ & (6) \\
\hline 21 & 山陽製鉄 & $0.5(0.5)$ & 4.12 & 大阪 & & & $\triangle$ & & $\triangle$ & & & - & $\triangle$ & & \\
\hline 22 & 沖見初炭坑 & $2(2)$ & $5.3(9)$ & 下関 & $\mathrm{O}$ & (O) & 0 & $\mathrm{O}$ & $\mathrm{O}$ & 0 & & - & 0 & $\triangle$ & 6 \\
\hline 23 & 朝解鉄道 & $54.5(17.65)$ & 5.4 & 朝鮮 & & & $\triangle$ & & $\triangle$ & & & + & $\triangle$ & & \\
\hline 24 & 日本金属 & $1(1)$ & 5.5 & 神户 & & $\theta$ & 0 & 0 & 0 & 0 & 0 & $\ldots$ & 0 & ) & 8 \\
\hline 25 & 日本火薬製造 & $2.5(1.375)$ & 5.6 & 東京 & & & $\triangle$ & & $\triangle$ & & & 1 & $\triangle$ & & \\
\hline 26 & 八重山産業 & $0.3(0.1125)$ & 5.8 & 神芦 & & (O) & & & & & & & & & \\
\hline 27 & 東洋燐才 & $2.8(2.8)$ & $5.9(7)$ & 神戸 & 0 & (O) & $\triangle$ & $\triangle$ & $\triangle$ & $\triangle$ & & + & $\triangle$ & $\triangle$ & \\
\hline 28 & 帝国汽船 & 1(1) & 5.10 & 神户 & 0 & $\theta$ & $\triangle$ & $\Delta$ & $\triangle$ & 0 & 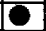 & - & 0 & 0 & 0 \\
\hline 29 & 帝国染料製造 & $0.555(0.555)$ & 5.11 & 福山 & & (0) & $\triangle$ & $\triangle$ & $\triangle$ & $\triangle$ & & - & $\triangle$ & $\triangle$ & (C) \\
\hline 30 & 福島崖坑 & $2(1.2)$ & 5.12 & 東京 & & & $\triangle$ & & $\triangle$ & & & 1 & $\triangle$ & & \\
\hline 31 & 佐賀紡績 & $5(3.5)$ & 5.12 & 佐贺 & & & $\triangle$ & $\Delta$ & & $\triangle$ & & & $\triangle$ & $\triangle$ & - \\
\hline 32 & 浪華倉庫 & $5(5)$ & 6.6 & 大阪 & 0 & $\theta$ & 0 & 0 & 0 & 0 & 7 & $\bar{t}$ & 0 & 0 & 0 \\
\hline 33 & 東海製油肵 & $0.5(0.125)$ & 6.6 & 名古屋 & & & $\triangle$ & & & & & & & & \\
\hline 34 & 関門空業 & $0.19(0.19)$ & 6.8 & 彦島 & & & $\triangle$ & $\triangle$ & $\triangle$ & & & - & $\triangle$ & $\triangle$ & \\
\hline 35 & 南洋製糖 & $1.25(1.25)$ & 6.11 & 東京 & & $\square$ & 0 & 0 & 0 & $\triangle$ & & + & $\triangle$ & $\triangle$ & \\
\hline 36 & 日沙商会 & $3(2)$ & 6.12 & 兵庫 & 0 & $\theta$ & 0 & 0 & $\triangle$ & $\overline{0}$ & & + & 0 & 0 & 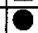 \\
\hline 37 & 帝国磷寸 & $0.2(0.2)$ & 7.1 & 神祭 & & & & & & & & & $\triangle$ & & \\
\hline 38 & 彦島坩城 & $0.3(0.3)$ & $7.2(3)$ & 彦島 & & (C) & 0 & 0 & $\mathrm{O}$ & & & - & $\overline{0}$ & 0 & \\
\hline 39 & 日本樟脑 & $9(6.75)$ & 7.2 & 神户 & $\mathrm{O}$ & $x$ & $\triangle$ & $\triangle$ & $\triangle$ & $\triangle$ & & & $\triangle$ & $\triangle$ & $\bar{x}$ \\
\hline 40 & 篣国人造絹系 & $12.5(8.75)$ & $7.2(6)$ & 神孚 & 0 & 0 & 0 & 0 & $\bar{O}$ & $\overline{0}$ & & & 0 & 0 & (C) \\
\hline 41 & 山陽水力電窔 & $6(4.5)$ & 7.9 & 神䍐 & & & & & & & & & $\triangle$ & & \\
\hline 42 & 千代田信託 & $10(2.5)$ & 7.10 & 東京 & & & $\triangle$ & $\triangle$ & $\triangle$ & & & 1 & $\triangle$ & $\triangle$ & \\
\hline 43 & 日本治金 & $0.35(0.35)$ & $8.3(7.11)$ & 大陙 & & $\square$ & $\triangle$ & $\triangle$ & $\triangle$ & 0 & & - & 0 & $\triangle$ & 7 \\
\hline 44 & 信越電力 & $32(32)$ & 8.5 & 菓京 & & & $\triangle$ & & $\triangle$ & $\triangle$ & & -4 & $\triangle$ & & \\
\hline 45 & 帝国炭業 & $10(10)$ & 8.5 & 下開 & 0 & (0) & 0 & 0 & $\mathrm{O}$ & 0 & & 1 & 0 & $\triangle$ & (c) \\
\hline 46 & 国際汽船 & $80(77.148)$ & 8.7 & 神百 & & & $\triangle$ & $\triangle$ & $\triangle$ & $\triangle$ & & - & $\triangle$ & $\triangle$ & $x$ \\
\hline 47 & 大日本セルロイド & $10(10)$ & 8.9 & 堺 & & $x$ & $\triangle$ & $\triangle$ & $\triangle$ & $\triangle$ & & + & $\triangle$ & $\triangle$ & $\bar{x}$ \\
\hline 48 & 大成化学工業 & $1(0.5)$ & 8.10 & 東京 & & $x$ & & & & & & & & & \\
\hline 49 & 内国食品 & $0.08(0.06)$ & 8.10 & 神戸 & & & 0 & & $\mathrm{C}$ & C & & $\overline{-}$ & 0 & & 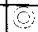 \\
\hline 50 & 太陽曹達 & $1(0.5)$ & 8.10 & 神司 & 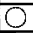 & $\theta$ & 0 & 0 & 0 & 0 & & 1 & 0 & 0 & 0 \\
\hline 51 & 三国紀䋶 & $5(2.5)$ & 8.10 & 大陙 & & & & & & & & & & & $\bar{x}$ \\
\hline 52 & 日本拓殖 & $10(3)$ & 8.11 & 台湾 & & & $\triangle$ & & $\triangle$ & $\triangle$ & & 1 & $\triangle$ & & \\
\hline
\end{tabular}

\section{Fig. 7.8 The Suzuki zaibatsu: Affiliated firms, 1923-27}

Source: Katsura (1976).

Notes: The 76 firms listed here were established between 1878 and 1926 and were generally considered members of the Suzuki zaibatsu. Analysts before and after World War II differ on the precise control relationships the Suzuki Shoten had with these Suzuki companies. Columns (A)-(G) and (I)-(K) compare the estimated control relationships published by ten different analysts and securities firms between 1923 and $1928 . \bigcirc=\mathrm{di}-$ rectly owned by Suzuki; $\odot$ = majority-controlled; $\boldsymbol{\Theta}=$ minority-controlled; $\mathrm{O}=$ fully controlled; $\bullet$ = spinoffs; $\Delta=$ affiliated (mostly for investment purposes); $\times$ = closely related with little control. Column $(\mathrm{H}) \mathrm{com}$ pares estimates of the chances of independent survival for former Suzuki companies, published in a business magazine after the Suzuki zaibatsu's collapse in April 1927. + = very good prospect, no impact from the collapse; $-=$ no possibility for survival; $\mid$ = survival possible depending on restructuring efforts. 


\begin{tabular}{|c|c|c|c|c|c|c|c|c|c|c|c|c|c|c|c|}
\hline & Company name & Paid-in & Date of & Location & & & & & & Note & & & & & \\
\hline & 会社(株)別 & $\begin{array}{l}\text { 資本金(払 } \\
\text { 込加) }\end{array}$ & 設立年月 & 所在地 & $A$ & $\mathrm{~B}$ & $\mathrm{C}$ & TD & $\mathrm{E}$ & $F$ & $G$ & $\mathrm{H}$ & TI & $J$ & $k$ \\
\hline 53 & 再製模脑 & $2(1.7)$ & 大正 8.12 & 神戸 & 0 & (c) & 0 & 0 & 0 & 0 & & + & 0 & $\triangle$ & \\
\hline 54 & 新日本火災海上 & $5(1.25)$ & 9.8 & 東京 & 0 & (c) & $\triangle$ & $\triangle$ & $\triangle$ & $\triangle$ & & + & $\triangle$ & $\triangle$ & \\
\hline 55 & 大源鈸竞 & $2(1.36)$ & 9.9 & 東京 & & $x$ & & & & & & & & & \\
\hline 56 & 支那樟脳 & $2(2)$ & 9.12 & 上海 & 10 & (c) & 0 & 0 & 0 & 0 & 1 & + & 10 & $\triangle$ & \\
\hline 57 & 樺太漁業 & $0.75(0.6)$ & 9.12 & 函館 & & $x$ & $\triangle$ & $\triangle$ & $\triangle$ & $\mathrm{O}$ & & - & 0 & $\triangle$ & \\
\hline 58 & 旭石油 & $9.6(9.3)$ & 10.2(11.3) & 東京 & & $\square$ & $\triangle$ & $\triangle$ & $\triangle$ & $\triangle$ & & - & $\triangle$ & $\triangle$ & \\
\hline 59 & 合同油脂グリセリン & $5(5)$ & 10.4 & 東京 & 0 & (c) & 0 & 0 & 0 & 3 & & ; & 0 & $\triangle$ & \\
\hline 60 & 太田川水電 & $3(0.75)$ & 10.10 & 神戸 & & & 0 & & 0 & 0 & & - & 0 & & \\
\hline 61 & 日本トロール & 2(1) & 10.10 & 東京 & & & $\Delta$ & $\Delta$ & $\triangle$ & & & $\dot{T}$ & $\Delta$ & & \\
\hline 62 & 米星煙草 & $1(0.5)$ & 10.12 & 青島 & 0 & 0 & $\triangle$ & $\triangle$ & $\triangle$ & 0 & C & + & 0 & 0 & \\
\hline 63 & 豊年製油 & $10(10)$ & 11.4 & 東京 & 0 & 0 & 0 & 0 & 0 & 0 & 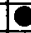 & + & 0 & 0 & \\
\hline 64 & クロード式窒業工業 & $10(10)$ & 11.4 & 神戸 & 0 & $\theta$ & 0 & 0 & 0 & 0 & 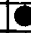 & 1 & 0 & 0 & \\
\hline 65 & 南朝鮮製紙 & $1(1)$ & 11.5 & 朝鮮 & 0 & 0 & 10 & 0 & 0 & 10 & & 1 & 10 & 0 & \\
\hline 66 & 大陸木材工業 & $0.75(0.75)$ & 11.6 & 神官 & 0 & (0) & 0 & 0 & & 0 & & & 10 & 0 & $(0$ \\
\hline 67 & 東京無線電機 & $1(0.25)$ & 11.10 & 東京 & & & $\triangle$ & $\triangle$ & $\triangle$ & 0 & & - & 0 & & \\
\hline 68 & 帝国樟脳 & $1(1)$ & 11.12 & 神户 & 0 & $\theta$ & 0 & 0 & 0 & 0 & & 1 & 10 & 0 & \\
\hline 69 & 株式鈴木 & $80(50)$ & 12.3 & 神戸 & & & & & & & & & & 0 & \\
\hline 70 & 日本輪業 & $1(0.6)$ & 12.3 & 兵庫 & & $\theta$ & 10 & 0 & 0 & 0 & 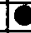 & 1 & 0 & 0 & \\
\hline 71 & 山陽電気軌道 & $4.5(0.45)$ & 13.3 & 下関 & & & $\triangle$ & $\triangle$ & $\triangle$ & & & 1 & & & \\
\hline 72 & 大日本酒類酮造 & $2.865(2.865)$ & 13.7 & 下関 & & (c) & $\Delta$ & $\triangle$ & $\triangle$ & 0 & & 1 & 10 & $\triangle$ & \\
\hline 73 & 日本エヤーブレーキ & $0.6(0.45)$ & 14.3 & 神声 & & & 10 & 0 & 0 & 0 & & 1 & 0 & & \\
\hline 74 & 紡機製造 & $0.2(0.2)$ & 14.5 & 神戸 & & & $\triangle$ & $\triangle$ & 0 & 0 & & 1 & 0 & & \\
\hline 75 & 言废府土地 & $1.5(0.375)$ & 14.12 & 長府 & & & & $\triangle$ & & & & & & 0 & \\
\hline 76 & 第一峌素工業 & $5(1.5)$ & 15. 6(5) & 神户 & & & 10 & 0 & 0 & 0 & & 1 & 10 & 0 & \\
\hline
\end{tabular}

Fig. 7.8 (cont.)

Kaneko apparently created some of these manufacturing companies out of a sense of nationalism. He shared with many Japanese managers of the era a belief that import substitution would free Japan of its ignominious dependence on foreigners.

The 1923 restructuring caused the Suzuki zaibatsu to take on a structure superficially resembling those of the other large zaibatsu. A holding company stood at the apex, major Suzuki powerhouse companies filled the first tier of subsidiaries, their spin-offs filled the second tier, and various acquired companies filled out the lower tiers. Many of these companies continued on with their original names.

However, two key differences figured in the Suzuki group's demise.

First, while Suzuki Shoten's trading division was separate from the apex holding company, there was no corresponding separation in personnel. In fact, figure 7.9 shows that numerous Suzuki family members and managers held cross-appointments in Suzuki companies. And though the Suzuki family held control rights, a hired manager, Kaneko, was actually making all the management decisions. The Suzuki group's rapid expansion of its business activities was not accompanied by a corresponding expansion of its management personnel.

Second, the Suzuki companies were financed differently. Suzuki firms borrowed much more than other zaibatsu firms, both to finance expansion 


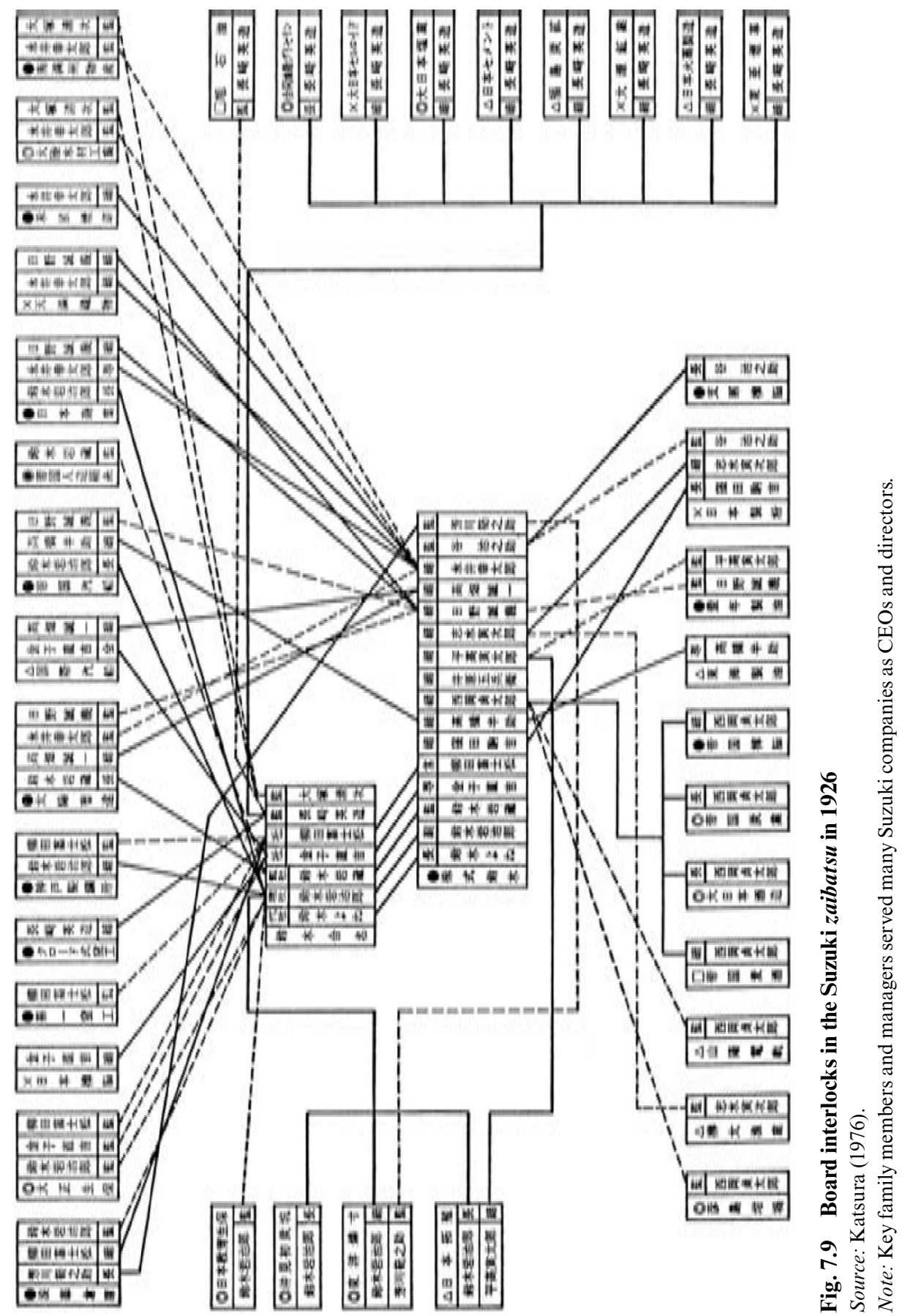


Suzuki Trading Company debt to the Bank of Taiwan (yen)

\begin{tabular}{rrr}
\hline Year & New debt & Total debt \\
\hline 1920 & & $80,811,300$ \\
1921 & $42,907,587$ & $123,718,887$ \\
1922 & $55,317,426$ & $179,036,313$ \\
1923 & $47,869,445$ & $226,905,758$ \\
1924 & $49,145,662$ & $276,051,420$ \\
1925 & $37,223,293$ & $313,274,713$ \\
1926 & $43,581,754$ & $356,856,470$ \\
1927 & $22,002,099$ & $378,858,569$ \\
\hline
\end{tabular}

Source: Fouraker (2002, p. 8).

and to finance day-to-day business dealings. This debt generally took the form of loans from the Taiwan Bank, the Suzuki group's de facto group bank. This seems to have reflected Kaneko's desire to maintain undisputed control throughout the pyramid. Equity financing risked empowering outside shareholders, and even invited takeovers, jeopardizing Kaneko's absolute control. Debt from sources other than the Taiwan Bank risked interference from outside creditors. This aversion led to a rapid buildup of Suzuki companies' debts to the Taiwan Bank, shown in table 7.8, and a similarly rapidly increasing exposure of the Taiwan Bank to the Suzuki companies' fortunes.

Soon, the bulk of the Taiwan Bank's loan portfolio was tied up in other Suzuki companies. However, the integration of the Taiwan Bank into the Suzuki group was via a "long-term relationship." Kaneko only controlled the Taiwan Bank because of its financial dependence on business with Suzuki companies. And the Suzuki group's financial position was weakened in the early 1920s because of a costly failed effort to merge two large flour companies, Nisshin and Nihon Flour Companies. Finally, most of Suzuki General Partnership's capital was tied up in Kabushiki Suzuki, the trading company.

The collapse of the Suzuki zaibatsu was spectacular. ${ }^{40}$

The September 1919 boom that Kaneko gambled on turned out to be short lived. The Japanese economy stumbled in 1920, and again in 1922, and then collapsed with the Great Kanto Earthquake depression of 1924, and the Showa finance depression of 1927 . The latter two events kept Japan's economy from realizing the growth that seemed likely in 1919 and exposed the weakness of the Suzuki zaibatsu and other similar pyramids.

The Great Kanto Earthquake of September 1, 1923, was one of the worst

40. The collapse of Suzuki zaibatsu compares in scale with the collapses of Ivar Kreuger's STAB in Sweden in 1932 and that of the Stinnes concerns in Germany in the 1920s (Kato 1957). 
in world history. It destroyed Tokyo, Yokohama, and the surrounding area, killing 140,000 people either directly, in the ensuing fires, or in mob violence against Koreans in the quake's aftermath. Business offices and records were destroyed, and much of Japan's most modern infrastructure was ruined.

But another effect of the earthquake was purely financial - the Showa depression. The earthquake seriously damaged numerous businesses, many of which had issued bills prior to the quake that they were now unable to pay. This, in turn, created cash flow problems for the banks holding those bills. The government therefore developed a program under which the Bank of Japan would rediscount bills listing the disaster area as place of payment or listing a merchant with offices in the disaster area as the debtor. These earthquake bills, or tegata, provided a two-year grace period for collection, subsequently twice extended, adding two more years of grace. The government promised compensation to the Bank of Japan for any losses due to the program. At the end of 1926, more than $¥ 200$ million in unsettled earthquake bills remained, of which $¥ 160$ million had been rediscounted by the Bank of Japan. ${ }^{41}$

Suzuki companies used more debt financing than Mitsui, Sumitomo, or Mitsubishi firms. The Suzuki group’s total debt at the end of 1926 was $¥ 500$ million, of which $¥ 379$ million was owed to the Taiwan Bank. Kaneko had accumulated this amount of debt through adept financial maneuvers mixing and counterbalancing credit created by the Taiwan Bank, Suzuki firms, other firms, and the Bank of Japan. Thus, a disproportionate fraction of these unpaid earthquake bills were for debts owed by Suzuki companies, and the Suzuki zaibatsu's bank, the Taiwan Bank, accounted for fully 58 percent. ${ }^{42}$

When the Japanese Diet debated how to absorb these unpaid promissory notes, Suzuki hired heavy-handed lobbyists to sway votes. The campaign backfired, and Suzuki's financial problems were exposed. Suzuki companies found themselves unable to float debt. The final law the Diet passed on March 23, 1927, was accompanied by a resolution to rescue the Taiwan Bank. On March 24, the Taiwan Bank announced that it was severing its ties with the Suzuki group entirely. The sudden abandonment of Suzuki companies by the Taiwan Bank forced them to default on payments due the Mitsui Bank and other banks. Angered by the Taiwan Bank's move, the other banks called in their Taiwan Bank loans, putting the Taiwan Bank (once again) on the verge of bankruptcy.

Suzuki collapsed on April 2, 1927. On April 13, the Bank of Japan, despite the above resolution, refused to mount a second rescue of the Taiwan

41. See, for example, Ito (2001) for the role of the Bank of Japan in the depression periods in the 1920s and 1930s.

42. Both Taiwan and Korea Banks were given special status by the Japanese government. 
Bank. Cha (2001) argues that a determination by the central bank to end the gold embargo figured largely in this decision, but the politics of the situation surely also played a role. The Upper House of Parliament voted down a special provision to rescue Taiwan Bank, arguing that the measure was unconstitutional, and the Japanese cabinet fell on April 17. The Taiwan Bank closed temporarily on April 18. This resulted in an immediate nationwide financial panic.

\subsubsection{The Disposition of the Remains}

Although the Suzuki group failed because of its inability to pay its promissory notes, it never actually went into bankruptcy. The Suzuki group moved all its business to another company, Nissho, reorganized as a stock company in $1928 .{ }^{43}$ The original Suzuki company undertook all repayment and restructuring activities and was dissolved in 1933 after repaying all of its debts. During this six-year restructuring, no creditors' meeting took place, and the Japanese courts never declared Suzuki bankrupt. In their investigations, the Suzuki group's creditors found no book fudging whatsoever, and accepted that the collapse was an honest financial and management failure. They unanimously agreed to settle all remaining accounts privately. In this process no overseas clients of the Suzukis' were adversely affected either.

Because the failure was purely financial and managerial, the Suzuki pyramid still contained viable firms with significant assets. These, realizing Kaneko's worst nightmares, fell to the other major zaibatsu as Suzuki debts were settled. The primary buyers were Mitsui and Mitsubishi, which accumulated all of the Suzuki group's most promising business units plus the Taiwan Bank. This consolidation significantly raised concentration ratios in certain industries. For example, 84 percent of Taiwan's sugar production was now under the control of three zaibatsu: Mitsui, Mitsubishi, and Fujiyama. Intangible assets, notably the many exclusive distribution rights the Suzuki group owned, were transferred to Mitsui Bussan (Mitsui and Co.) and Mitsubishi Shoji (Mitsubishi Corp.), the general trading firms of those groups.

Suzuki had been willing to take risks. The established zaibatsu groups, such as Mitsui, Mitsubishi, and Sumitomo, had been much more cautious. After acquiring Suzuki's chemical companies - including plants, patents, engineers, and scientists-Mitsui established a major ammonia production facility. Mitsui clearly used research conducted by the former Suzuki companies, whereas Mitsui itself would never have paid for such research - at least without large government subsidies. Thus, although the

43. Nissho Company continued as a general trading firm and merged with Iwai Trading Company in 1968 to form the present Nissho Iwai Corporation. Their web site (http:// www.nisshoiwai.co.jp/in/e/index2.html) presents their corporate history involving the Suzuki Shoten. 
Suzuki group ultimately failed, it still probably made a major contribution to Japan's subsequent development. ${ }^{44}$

\subsubsection{Post Mortem}

Kaneko (1928) himself reflected on the collapse of the Suzuki zaibatsu and summarized the reasons for its collapse. In Kaneko's opinion, a highly centralized management system imposed on widely disparate firms prevented proper monitoring and was the most important reason for Suzuki's ruin. Second, Kaneko reflects that Suzuki companies had too much debt capital requiring too high interest payments given the recessionary environment, noting that the "high cost of debt capital subsequently killed us."

The two reasons Kaneko lists correspond precisely to the differences noted above between the Suzuki pyramid and the zaibatsu that survived, such as Mitsui, Sumitomo, and Mitsubishi. The Suzuki group's organizational weakness, as pointed out by Kaneko himself, was its overly centralized management. The Suzuki group's financial weakness stemmed from its extensive use of debt financing from a single bank. Kaneko, quoted by Nissho (1968), explains that "the profits earned by Suzuki Shoten's hard work should be monopolized by the Suzuki family. I would rather borrow money from banks than pay profits out as dividends." The two reasons were not unrelated, for this statement is often interpreted to mean that Kaneko wanted to maintain Suzuki family control in order to preserve his own control. This left Taiwan Bank's loan portfolio highly concentrated in Suzuki companies - and essentially an organ bank for the group. In contrast, by 1912 most Mitsui companies were already able to grow on retained earnings and equity issues. The Mitsui Bank was not needed as an organ bank, and lent extensively to companies outside the Mitsui group. Table 7.9 shows quite stable relationships between deposits and loan balances for the six largest zaibatsu banks for the early 1930s.

A third reason, which Kaneko does not mention, for the Suzuki group's collapse is that he expanded the Suzuki group too fast and in the wrong directions. He certainly failed to foresee the chronic weakness of the Japanese economy through the 1920s. Had the 1920s economy in Japan resembled that in the United States, Suzuki might well have prospered. However, in retrospect, the more risk-averse strategies of the Mitsui, Mitsubishi, and Sumitomo groups proved superior. Moreover, Suzuki missed some of the most profitable new industries of the 1920s, such as electrical machinery. The Suzuki group was vulnerable to a downturn because, unlike Mitsui, Mitsubishi, and Sumitomo, it lacked a reliably highly profitable mining op-

44. After the collapse of Suzuki, Kaneko set up a holding company, Taiyo Soda, in 1931, with which he began another business career. He died in Borneo in 1944, while engaged in aluminum processing. Takahata was at his deathbed. Kaneko, with help from Nissho, developed Taiyo Soda (renamed Taiyo Sangyo in 1939) into a holding firm controlling twenty-five companies, including Kobe Steel Works. 
Table 7.9

\begin{tabular}{lcccrrr}
\hline Date & Mitsui & Mitsubishi & Daiichi & Sumitomo & Yasuda & Sanwa \\
\hline June 1931 & $710(413)$ & $647(313)$ & $659(371)$ & $684(402)$ & $610(438)$ & \\
June 1932 & $620(441)$ & $616(344)$ & $648(394)$ & $679(423)$ & $607(460)$ & \\
December 1932 & $687(429)$ & $640(317)$ & $703(399)$ & $735(447)$ & $664(479)$ & \\
June 1933 & $696(386)$ & $705(324)$ & $769(406)$ & $815(472)$ & $730(507)$ & \\
December 1933 & $715(409)$ & $661(274)$ & $787(418)$ & $798(461)$ & $740(511)$ & $1,025(519)$ \\
June 1934 & $759(366)$ & $696(259)$ & $816(409)$ & $827(426)$ & $800(519)$ & $1,063(489)$ \\
December 1934 & $748(383)$ & $722(265)$ & $852(422)$ & $872(466)$ & $807(548)$ & $1,077(496)$ \\
June 1935 & $759(380)$ & $752(265)$ & $868(432)$ & $886(471)$ & $818(571)$ & $1,080(494)$ \\
December 1935 & $796(451)$ & $730(294)$ & $913(448)$ & $952(522)$ & $832(578)$ & $1,114(494)$ \\
June 1936 & $824(437)$ & $805(341)$ & $940(450)$ & $970(543)$ & $891(616)$ & $1,151(526)$ \\
December 1936 & $856(518)$ & $810(370)$ & $972(545)$ & $1,017(618)$ & $928(679)$ & $1,197(532)$ \\
June 1937 & $904(531)$ & $903(441)$ & $1,054(657)$ & $1,093(691)$ & $1,023(744)$ & $1,263(577)$ \\
\hline
\end{tabular}

Source: Mitsubishi Bank (1954).

Note: Loans in parentheses.

eration to serve as a cash cow for the entire groups during downturns. It is also sometimes argued that the lack of mining in its industrial portfolio prevented Suzuki from vertically integrating into electrical machinery, which provided an additional financial cushion for the Mitsui, Mitsubishi, and Sumitomo zaibatsu.

A fourth reason, which Kaneko also fails to note, is that he was quite ham-fisted at lobbying. An interesting aspect of Kaneko's personality was that he apparently had no interest in personal wealth. He did not benefit personally in any way from his business dealings. He likewise could not comprehend that politicians might value money, and he refused to make any payments to bureaucrats or politicians. During the Meiji period, rent-seeking investments seem to have been important aspects of the business strategies of the other zaibatsu, and they probably played some role in Mitsui and Mitsubishi taking over state mining operations. Tousuke Fukuzawa (1868-1938), a successful entrepreneur and well-known industrialist responsible for much of the development of Japan's electric power industry in the early decades of the twentieth century, argues that this was the biggest reason for the Suzuki group's collapse and that Japan should thank Kaneko deeply for not contributing to political corruption. ${ }^{45} \mathrm{~A}$ less laudatory interpretation is that Kaneko relished power rather than wealth and failed to understand that others viewed life differently. In any event, Kaneko's lack of preexisting political connections certainly hurt him, and his last-minute attempts to manipulate the Diet backfired badly.

45. Fukuzawa (1930) regards Kaneko more highly than Iwasaki, the Mitsubishi zaibatsu's founder. 


\subsubsection{The Culling of the Zaibatsu and Their Banks}

Although the fall of the Suzuki zaibatsu was the most spectacular, it was not an isolated event. The 1920s depressions felled many other pyramidal groups. The Nakazawa, Watanabe, and Matsusaka zaibatsu also collapsed about the same time as the Suzuki zaibatsu.

Like the Suzuki group, these families preserved control by using loans from their group banks to finance group companies. Thus, like the Taiwan Bank, the Nakazawa, Watanabe, and Matsusaka banks were organ banks of their zaibatsu - heavily dependent on interest payments from their respective group companies. When key nonfinancial companies in each of these zaibatsu encountered financial difficulty, the group bank failed and the rest of the zaibatsu then collapsed.

Moreover, these organ banks were located deep in their pyramids. Consequently, tunneling would have concentrated losses and debts in the banks, with income and assets rising toward the apex firms. In contrast, the banks of the Mitsui, Sumitomo, and Mitsubishi zaibatsu were near the apexes of those pyramids. Consequently, tunneling would have concentrated income and assets in the banks, with losses and debts sinking toward the lower-tier firms.

Noting this pattern, Kato (1957) proposes the so-called organ bank hypothesis. This hypothesis holds that certain banks were excessively tightly connected to their zaibatsu industrial companies, made easy loans to those companies, failed, and caused the Showa financial crisis in 1927. Okazaki and Yokoyama (2001) present empirical evidence supporting this hypothesis.

Since the stability of a country's banking system has positive externalities, there may be a public policy lesson here. Countries whose major banks are parts of pyramidal groups should encourage the positioning of banks near the apexes of those groups.

\subsection{The Centrally Planned Economy under the Military Government}

As the economy staggered, an anti-Westernization backlash grew. In part, this was a result of Japan's successful adoption of many Western ideas. Japanese, now educated and middle class, chafed at Western arrogance when the Americans and British rejected Japan's proposal for a racial equality clause in the League of Nations Covenant. A revival of conservative and nationalistic feelings renewed interest in bushido.

Japan had taken Taiwan from China in 1895, gained a foothold in Manchuria by defeating Russia in 1905, annexed Korea in 1910, and installed the emperor of China in a puppet government in Manchuria in 1931. These victories amid economic stagnation elevated the prestige of the military and weakened that of the political and business elite. 
Emboldened, the military slowly seized power by assassinating civilian politicians. Navy and army officers soon held most important public offices, including that of prime minister. Japan attacked China in 1937, and by 1942 it had conquered Hong Kong, Indochina, Singapore, Indonesia, and Burma, proclaiming a Greater East Asian Co-Prosperity Sphere.

To support the war effort and further consolidate its power, the military government enacted laws that stripped shareholders of their corporate governance powers. Japan was soon a rigidly centrally planned economy. Although zaibatsu families retained titular ownership of control blocks, they had little say in management, and dividends were restricted so that earnings could be reinvested patriotically. The military government denigrated the families' objections as unpatriotic shareholder fixation on current dividends. Thus, by 1945, Japan had an economy little different from that of Russia in the 1920 s. ${ }^{46}$

\subsubsection{The Military Buildup}

By the mid-1930s, Japan was recovering from its prolonged bout of depressions. In part, this was because the yen depreciated sharply after Japan left the gold standard, triggering a surge in textile exports. ${ }^{47}$ This depreciation also gave domestic heavy industry and chemical industry firms an advantage over imports, allowing them to expand (Teranishi 2000).

In part, the recovery also probably stemmed from Finance Minister Korekiyo Takahashi's adoption of Keynesian policies at the end of 1931, when the government issued deficit-covering bonds underwritten by the Bank of Japan that were then sold to city banks. The government spent the proceeds on public works and military industries, which further increased demand for heavy and chemical industry products.

And in part, the recovery was due to the Manchurian Incident of September 1931, when a bomb ripped through a Japanese-built railway near Mukden (Shenyang). The Japanese Kwantung army, or Kantogun, which planted the bomb while guarding the railway, used the incident as a pretext to occupy Southern Manchuria despite the government's direct order to withdraw. A subsequent military buildup elevated demand for chemicals and heavy industry products.

Rising military spending seemed increasingly linked to economic prosperity in the minds of business leaders, politicians, and ordinary Japanese.

46. See Okazaki (1994) for details. Wartime Japan was, of course, not a communist country. However, the economic structure imposed by its extreme right military government was surprisingly similar to that of Russia in the 1920's, as described by Hoskins (1992).

47. Japan abandoned the gold standard in September 1917, along with many other countries. After World War I, many other countries promptly returned to the gold standard, but Japan delayed doing so until January 1930. It then abandoned the gold standard again in December 1931. For details, see Ogura (2002). 
Japanese production output by industry, 1929 and 1942 (in 1,000 yen)

\begin{tabular}{|c|c|c|c|c|}
\hline \multirow[b]{2}{*}{ Rank } & \multicolumn{2}{|l|}{1929} & \multicolumn{2}{|l|}{1942} \\
\hline & Industry & Output & Industry & Output \\
\hline 1 & Raw silk & 795,599 & Iron and steel & $2,626,512$ \\
\hline 2 & Cotton yarn & 678,466 & Navy and army arsenals & $2,294,100$ \\
\hline 3 & Electric power & 658,316 & Aircraft & $1,930,400$ \\
\hline 4 & Broad cotton fabrics & 526,096 & Guns, bullets, and weapons & $1,915,242$ \\
\hline 5 & National railways & 517,795 & National railways & $1,441,921$ \\
\hline 6 & Japanese sake & 302,120 & Electric power & $1,375,943$ \\
\hline 7 & Coal mining & 245,762 & Coal mining & $1,077,769$ \\
\hline 8 & Private railways & 232,254 & Shipbuilding & 858,377 \\
\hline 9 & Military ordinance & 208,537 & Industrial chemicals & 785,169 \\
\hline 10 & State-run steel mills & 189,551 & Special steel & 753,170 \\
\hline 11 & Printing & 186,304 & Electrical machinery & 633,292 \\
\hline 12 & Wool fabrics & 176,896 & Medicine & 630,800 \\
\hline 13 & Steel products & 173,833 & Private railways & 560,337 \\
\hline 14 & Sugar & 158,125 & Lumber & 551,600 \\
\hline 15 & Flour milling & 134,895 & Pig iron & 502,631 \\
\hline 16 & Chemical fertilizers & 132,711 & Raw silk & 463,098 \\
\hline 17 & Broad silk fabrics & 129,516 & Metal machine tools & 449,442 \\
\hline 18 & Lumber & 112,170 & Coke & 421,210 \\
\hline 19 & Nonferrous metal mining & 108,204 & Cotton yarn & 327,520 \\
\hline 20 & Copper & 108,166 & Tools & 323,895 \\
\hline
\end{tabular}

Source: Yamazaki (1988, p. 13).

When the Second Sino-Japanese War broke out in 1937, the Japanese government mobilized the economy, emphasizing military-related industries and shifting production away from light industries, like textiles. Table 7.10 illustrates. This rapid change in Japan's industrial structure, in turn, had a major impact on the corporate sector.

The older zaibatsu-Mitsui, Sumitomo, and Mitsubishi-had expanded aggressively into heavy industries and chemicals from the early 1930s on, financing this expansion with equity issues. Table 7.11 shows that these became their most profitable operations in the 1940s, accounting for about 30 percent of the fifty most profitable firms. Thus, while the number of established zaibatsu firms in the top fifty did not change greatly, their industrial composition did.

Until the early 1930s the first-tier subsidiaries in the zaibatsu pyramids, except Mitsubishi, were almost wholly owned by members of the zaibatsu family and the apex firms collectively, as shown in table 7.12. In the 1930s, however, the zaibatsu listed these first-tier subsidiaries. This was because the families saw immense profit opportunities in rapidly growing militaryrelated industries if they moved quickly, as illustrated in table 7.13. Superfluous stakes in control chains throughout the established pyramids were 


\begin{tabular}{|c|c|c|c|c|c|}
\hline & 1929 & 1943 & 1955 & 1973 & 1984 \\
\hline State-controlled firms ${ }^{a}$ & 9 & 20 & 2 & 2 & 3 \\
\hline Firms & 5 & 14 & & & \\
\hline Banks & 4 & 6 & & & \\
\hline Foreign-controlled firms & 0 & 0 & 0 & 1 & 1 \\
\hline Zaibatsu total & 16 & 25 & 23 & 23 & 19 \\
\hline "Old" zaibatsu total & 16 & 17 & & & \\
\hline Mitsui & 7 & 7 & 3 & 4 & 3 \\
\hline Mitsubishi & 5 & 6 & 6 & 7 & 6 \\
\hline Sumitomo & 2 & 1 & 2 & 3 & 2 \\
\hline Yasuda & 1 & 1 & & & \\
\hline Furukawa & & 1 & & & \\
\hline Asano & 1 & 1 & & & \\
\hline "New" zaibatsu total & & 8 & & & \\
\hline Nissan & & 5 & & & \\
\hline Nichitsu & & 2 & & & \\
\hline Nisso & & 1 & & & \\
\hline Keiretsu total $^{\mathrm{b}}$ & & & 23 & 23 & 19 \\
\hline "Old" keiretsu total & & & 11 & 14 & 11 \\
\hline "New" keiretsu total & & & 12 & 9 & 8 \\
\hline Fuji & & & 4 & 5 & 3 \\
\hline Sanwa & & & 5 & 2 & 3 \\
\hline Daiichi-Kangyo & & & 3 & 2 & 2 \\
\hline Independent & 29 & 14 & 25 & 24 & 27 \\
\hline
\end{tabular}

Source: Yamazaki (1988, p. 17).

an 1943 three Manchurian firms are double-counted to be affiliated with both the government and the Nissan zaibatsu.

${ }^{b}$ For the post-WWII years, firms with two keiretsu affiliations, such as Hitachi, Ltd., and Nippon Express, are counted as independent.

Table 7.12 Number of first-tier subsidiaries and stockholding ratios (1928)

\begin{tabular}{|c|c|c|c|}
\hline \multirow[b]{2}{*}{ Zaibatsu } & \multirow{2}{*}{$\begin{array}{l}\text { Number } \\
\text { of first-tier } \\
\text { subsidiaries }\end{array}$} & \multicolumn{2}{|c|}{ Stockholding ratio } \\
\hline & & $\begin{array}{l}\text { Shares held by family } \\
\text { and headquarters (\%) }\end{array}$ & $\begin{array}{c}\text { Shares held by all members } \\
\text { of the same zaibatsu (\%) }\end{array}$ \\
\hline Mitsui & 6 & 90.2 & 90.6 \\
\hline Mitsubishi & 10 & 69.4 & 77.6 \\
\hline Sumitomo & 13 & 79.1 & 80.5 \\
\hline Yasuda & 12 & 31.7 & 48.1 \\
\hline Furukawa & 4 & 72.8 & 89.4 \\
\hline Asano & 6 & 50.8 & \\
\hline Okura & 20 & 84.7 & 92.7 \\
\hline
\end{tabular}

Source: Takahashi (1930b). 
Shareholding by large block holders

\begin{tabular}{lcc}
\hline & 1919 & 1936 \\
\hline No. of sample firms & 379 & 477 \\
Holdings by large shareholders & & \\
$\quad$ No. of large shareholders (\%) & 0.59 & 0.36 \\
$\quad$ Shares held by large shareholders (\%) & 21.0 & 37.4 \\
Shares held by other types of shareholders & & \\
$\quad$ Individuals (\%) & 15.5 & 5.9 \\
$\quad$ Banks (\%) & 0.8 & 2.1 \\
$\quad$ Insurance/securities/trust firms (\%) & 0.5 & 4.8 \\
Corporations (\%) & 3.1 & $20.7^{\mathrm{b}}$ \\
Average number of shareholders per firm & 2,040 & 3,589 \\
Average number of shares held per shareholder & & \\
12 largest shareholders & 4,644 & 17,434 \\
$\quad$ Other & 103 & 95 \\
\hline
\end{tabular}

Source: Takeda (1995).

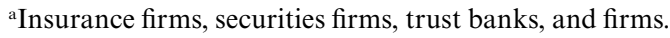

${ }^{b}$ Holding firms owned 53.8 percent of these shares owned by corporations.

sold to the public to raise capital for expansion. Thus, the stakes of zaibatsu companies in their subsidiaries declined significantly between 1929 and 1943 (table 7.14).

Table 7.11 shows that the newer zaibatsu were also present in these profitable sectors, with eight of their affiliates among the most profitable firms of 1943. Most notably, Japan Industries represents Nissan, Japan Nitrogenous Fertilizer represents Nichitsu, Nippon Soda represents Nisso, Mori Industrial Enterprises represents Mori, and the Physical and Chemical Research Institute represents Riken. Recall that many of these newer zaibatsu groups were developed by single entrepreneur chemists or engineers.

The number of independents among the most profitable firms fell from twenty-nine to fourteen, perhaps in part because of the state's increased control over the zaibatsu. Table 7.15 reveals the decreasing controlling family stakes in independent enterprises, as these firms issued ever more equity to finance expansion. By 1943, family holding company stakes were less than the stakes of state-controlled banks, like the Industrial Bank of Japan, which were now the most significant shareholders in many independent firms. ${ }^{48}$

48. The Industrial Bank of Japan was created in 1900 under the Industrial Bank of Japan (IBJ) Act, which provided $¥ 10$ million in government money as initial capital and granted it the privilege of issuing IBJ long-term debentures to raise further funds. The IBJ began operating as an investment bank in 1902. A 1918 revision of the IBJ Act let it underwrite securities. The IBJ Act was nullified in 1950, and the IBJ became an ordinary bank. Also in 1950, the government passed the Bank Debentures Issuance Act, which let ordinary banks issue long-term bonds to raise capital. In 1952, after the Allied occupation ended, the Japanese government abolished the BDI Act and passed the new Long-Term Credit Bank Act. This 


\begin{tabular}{|c|c|c|c|c|}
\hline \multirow[b]{2}{*}{ Subsidiary } & \multicolumn{2}{|c|}{ No. of shareholders } & \multicolumn{2}{|c|}{$\begin{array}{c}\text { Combined stake of } \\
\text { other zaibatsu } \\
\text { companies }(\%)\end{array}$} \\
\hline & 1929 & 1943 & 1929 & 1943 \\
\hline \multicolumn{5}{|c|}{ A. First-tier subsidiaries' ownership structure } \\
\hline Mitsui Bussan & 31 & 15,155 & 100 & 75.8 \\
\hline Mitsui Mining & 26 & 6,912 & 100 & 84.8 \\
\hline Mitsubishi Shipbuilding & 23 & 6,912 & 100 & 40.9 \\
\hline Mitsubishi Shoji & 20 & 5,940 & 100 & 47.2 \\
\hline Sumitomo Steel & 14 & 7,557 & 100 & 41.4 \\
\hline \multicolumn{5}{|c|}{ B. First-tier subsidiaries that experienced mergers } \\
\hline Oji Paper Co. & 6,000 & 23,516 & 25.2 & 3.5 \\
\hline \multirow[t]{2}{*}{ Toshiba Electric } & 211 & 5,885 & 58.4 & 15.1 \\
\hline & & 1929 & 1943 & \\
\hline \multicolumn{5}{|c|}{ C. Average percentage ownership of group companies by other zaibatsu companies } \\
\hline Mitsui & & 51 & 31.7 & \\
\hline Mitsubishi & & 52.5 & 35.2 & \\
\hline Sumitomo & & 52.9 & 32.8 & \\
\hline Yasuda & & 46.4 & 58.3 & \\
\hline Furukawa & & 65.2 & 44.5 & \\
\hline Asano & & 19.8 & 21.5 & \\
\hline
\end{tabular}

Source: Yamazaki (1988).

\subsubsection{The March to Serfdom}

The military assumed dictatorial powers over the economy in stages. Thus, the latter part of the 1930s is called the creeping war economy.

This development was possible because the weak economy convinced many in Japan, as elsewhere, that democracy and free-market capitalism had failed. Indeed, this view was widespread among business leaders themselves. In response to the Suzuki failure, the government organized the Council on Commerce and Industry in 1927. The council recommended a thorough cartelization of the economy to allow "cooperation" and government educational measures to induce "patriotic economic behavior" by consumers.

The Ottawa Imperial Conference erected tariffs around the British Commonwealth, shutting Japan out of her best markets, and the ensuing breakdown of trade allowed the council's recommendations to move forward.

designated long-term credit banks and granted them the privilege of issuing long-term bonds to finance corporate investment. The IBJ, along with the Long-Term Credit Bank, the Japan Credit Bank, and the Bank of Tokyo, became a long-term credit bank. For further details, see, e.g., Patrick (1967) and Tamaki (1995). We are grateful to Richard Sylla for pointing this out. 


\begin{tabular}{|c|c|c|c|c|}
\hline & $\begin{array}{c}\text { Corporations } \\
(\%)\end{array}$ & $\begin{array}{c}\text { Financial } \\
\text { institutions } \\
(\%)\end{array}$ & $\begin{array}{c}\text { Family holding } \\
\text { companies } \\
(\%)\end{array}$ & $\begin{array}{c}\text { Individuals } \\
(\%)\end{array}$ \\
\hline \multicolumn{5}{|l|}{1929} \\
\hline Toyo Spinning & 3.1 & 0.8 & 1.1 & 8.0 \\
\hline Osaka Godo Spinning & 6.2 & 2.3 & 1.9 & 7.1 \\
\hline Dai Nippon Spinning & 5.5 & & 1.1 & 7.0 \\
\hline Sanjushi Bank & 4.6 & 0.9 & 2.4 & 6.9 \\
\hline Yamaguchi Bank & 36.2 & 1.0 & 33.3 & 10.7 \\
\hline Kamoike Bank & 85.6 & & 82.9 & 13.3 \\
\hline Dai Nippon Sugar Mfg. & 6.9 & 2.8 & 2.9 & 6.0 \\
\hline Dai Nippon Breweries & 10.8 & 2.1 & 8.7 & 3.0 \\
\hline Nippon Oil & 9.1 & 1.9 & 7.2 & 7.4 \\
\hline \multicolumn{5}{|l|}{ Kobe Steel Works } \\
\hline Kawasaki Shipbuilding & 17.0 & & 15.9 & 15.2 \\
\hline Osaka Mercantile Steamship & 3.1 & & 1.5 & 4.4 \\
\hline Meguro-Kamata Electric Railway & 28.1 & 23.5 & 4.5 & 30.4 \\
\hline \multicolumn{5}{|l|}{1943} \\
\hline Toyo Spinning (merged) & 8.2 & 2.8 & 1.1 & 3.5 \\
\hline Dai Nippon Spinning & 7.6 & 1.8 & 1.0 & 3.1 \\
\hline Sanwa Bank (merged) & 19.2 & 4.9 & 14.2 & 4.7 \\
\hline Dai Nippon Sugar Mfg. & 22.1 & 17.4 & 4.7 & 1.6 \\
\hline Dai Nippon Breweries & 13.8 & 10.8 & 1.2 & \\
\hline Nippon Oil & 9.4 & 2.9 & 5.6 & 9.5 \\
\hline Kobe Steel Works & 38.7 & 27.2 & & \\
\hline Kawasaki Heavy Ind. & 29.5 & 4.2 & 2.5 & \\
\hline Osaka Mercantile Steamship & 5.8 & 1.5 & 0.4 & 1.2 \\
\hline Meguro-Kamata Electric Railway & 25.5 & 13.8 & 2.9 & 2.2 \\
\hline
\end{tabular}

Source: Yamazaki (1988, p. 38).

The 1931 Important Industries Law sanctioned cartels run by "control committees" of officials, and executives would designate crucial industries in which cartels should regulate production and prices. Cartels could be formed in any industry where at least half of the firms requested it. If twothirds of the firms requested cartelization, the remaining firms could be forced into the cartel. The minister could rescind cartel actions only with the approval of the control committee. ${ }^{49}$ The control committees, of course, would end up staffed by military personnel.

The mood of the times is well captured by Takahashi (1930a), who blames shortsighted shareholders who care only for high dividends and neglect the long-term future of the firm. He declares that

The primary manifestations of "the degeneration of firm management" were the short-sighted attitude towards business management and the 
inability of management to aim at so-called "business prosperity for 100 years." ... [D] egeneration of company management was largely caused by the "high handed and short sighted selfishness of large stockholders" and the corruption of the board of directors. (quoted in Okazaki, 1994, pp. 4-5)

He also asserts that corrupt, inept directors preoccupied with big bonuses and stock manipulation governed Japan's large companies and that

It is uncommon to find members of the board of directors who acquired their status and position by virtue of their management ability. A large number of directors get their position on the board only because of being large stockholders of the firm or having special relations in government circles. (quoted in Okazaki 1994, p. 233)

Takahashi thus blamed Japan's economic malaise on corrupt, inept, and entrenched directors placed in charge of large companies by dint of family history or political rent seeking. The military largely accepted (or at least exploited) these views, and concluded not only that it should take over the task of corporate governance but also that there would be broad public support for this. They were correct.

Thus followed a creeping nationalization of the banking system and the zaibatsu. Ironically, Okazaki (1994) argues that zaibatsu firms were actually the better performers because their dominant shareholders were more likely to entrust governance to professional managers. Thus, they ought to have been less vulnerable to such attacks. This was not the case.

The attack was three-pronged. First, the banking sector was placed under state control. Second, the zaibatsu families were isolated and their control rights negated. Third, a full-fledged central planning system was erected. It is still a matter of debate whether this strategy was planned from the beginning or whether the military government simply acted as opportunities presented themselves.

State control encompassed the banking sector in two ways. First, the government proposed to stabilize the sector by implementing a one-localbank-per-prefecture policy. ${ }^{50}$ Still traumatized by the recent depressions, the bankers gratefully accepted this largesse. This objective was achieved by the end of World War II, reducing the number of banks from 1,402 in 1926 to 377 in 1937 to only 61 in 1945 . While this policy did stabilize the banking sector, it also erected an insurmountable barrier to entry. Bank fi-

50. The Bank Law of 1927 let the government restructure the banking industry, and the number of banks fell sharply. This law, which was not substantially revised until 1981, gave the government considerable flexibility in regulating bank competition. For example, the Ministry of Finance used it to announce its one-bank-per-prefecture policy in 1933, giving these banks a degree of monopoly power according to Horiuchi (1999). The policy was implemented fully in the 1940s but temporarily relaxed in the early 1950s when the Ministry of Finance allowed twelve new small banks. The policy was subsequently tightened again. 
nancing was now in the hands of a relatively small cadre of people, whom the military government could either control or replace.

At the same time, the Japanese government increased the amount of funds supplied by the state-owned long-term credit banks, such as the Industrial Bank of Japan. This made the state a major creditor to many industrial companies. State banks also increasingly took equity positions, explaining the observation in table 7.11 that these organizations had become the most significant shareholders in many independent companies. Thus, when the cabinet decided in November 1938 to regulate loans, the number of banks to be controlled was small and their dependence on state power was evident to all bankers. By then, most senior economic planners under Japan's right-wing military government were Soviet trained.

The military government pried corporate control away from the zaibatsu families in two steps. Again, it is not clear that this was fully premeditated, though it might have been.

The first step was the conversion of the apex holding companies from limited partnerships into joint-stock companies. This was done through inheritance and dividend income tax reforms in 1937 and 1938 that made partnerships unviable. Dividend income was subjected to double taxation - once as corporate income of the partnership and again as personal dividend income of the family. The latter was at an especially high rate. ${ }^{51}$ However, if the holding company was a joint-stock company rather than a partnership, double taxation could be avoided. ${ }^{52}$ By 1940, the holding companies at the apexes of all Japan's major zaibatsu had been transformed from partnerships into joint stock companies.

At this point, Nissan was favored over other zaibatsu groups such as Mitsui, Mitsubishi, and Sumitomo by the military government because its apex firm, unlike those of the other major zaibatsu, was not family controlled..$^{53}$ This favored status led to a drastic change in the organization of the Nissan zaibatsu when Nissan was renamed the Manchurian Heavy Industry Company and recapitalized as a fifty-fifty joint venture with the Japanese and Manchurian governments. The Manchurian Heavy Industry

51. The partnership was subject to an income tax of between 18 and 28 percent, depending on the location of business, plus a capital tax. The same income was then subject to a personal income tax with a top marginal rate of 65 percent.

52. For details, see Morikawa (1992, p. 213). Corporate income tax was only introduced in Japan in a 1940 reform, which also increased tax burdens across the board. See Shiomi (1957) for general information on these changes. Miyamoto (1984) describes the previous tax regime in detail.

53. Reischauer (1988, p. 305) writes that "by the 1920 s and 1920 s there was widespread condemnation of the zaibatsu, particularly by the supporters of the military, as elements of Western decadence in Japanese society, corrupters of the parliamentary system, and money grubbing betrayers of Japan's imperial destiny." The lives of many zaibatsu leaders were threatened. For example, Ikuma Dan (1858-1932), a former civil servant and chairman of Mitsui Gomei (Mitsui Partnership), was assassinated by young naval officers in front of the Mitsui Bank in Tokyo in 1932. 
Company was granted a monopoly on all development projects in Manchuria.

The government also acquired controlling interests in a variety of previously independent firms. However, other zaibatsu firms remained under the control of their family shareholders.

The military government's second step was to cut off the income of the zaibatsu families. The same November 1938 cabinet decision that regulated loans also placed dividends under state control. This was justified as a patriotic measure to build up Japan's industries by raising retained earnings. Since the apex companies of the zaibatsu were now joint-stock companies, the zaibatsu families were entirely dependent on dividends for their income. These were apparently now sharply curtailed. Thus, Asajima (1984), noting that the Sumitomo group expanded dramatically from 1937 to 1945 using retained earnings, remarks that "if all the income from dividends is channeled into paid-up capital, the question arises as to what the Sumitomo family relied on for income. This is also unclear at present" (p. 110).

On September 13, 1940, the State Planning Ministry, the Kikakuin, announced its new Outline of the Establishment of a New Economic System, under which firms were "set free from the control of shareholders" and subjected to a system of quantitative production orders. Thus, the Kikakuin set up full-fledged central planning system, in which it assumed the role of Gosplan..$^{54}$ Under this system, the Kikakuin issued production orders to industry control boards, or toseikai, which in turn issued orders to individual firms. The cabinet explicitly commissioned the Kikakuin to investigate and imitate Soviet best practice. In all of this restructuring, firms were seen as consisting of workers and manager/bureaucrats. There was no mention of shareholders, for they were by now effectively irrelevant.

The Kikakuin also took control of the banking system, directing banks to transfer capital to firms in accordance with the central plan. ${ }^{55}$ The Mitsubishi apex company began issuing bonds to obtain the needed funds, while the Mitsubishi Bank and Mitsubishi Trust Co.- deviating from their prior practice - began large-scale lending to other Mitsubishi companies.

The planners who set quantitative targets for output also controlled the prices of goods and services throughout the economy. By early 1945 (the war ended in August 1945), the state was setting about ten thousand prices.

By 1942, the economy was in a state of crisis because many firms failed to meet production quotas. Okazaki (1994) writes that the officials at the Kikakuin now realized that firms were still thinking about production in terms of making profits, and were not willing to "bear sacrifices" despite the removal of stockholder influence.

54. Gosplan (Госплан) was the command and control section of the Soviet government. Okazaki (1994) states that Kikakuin was explicitly modeled on Gosplan and staffed by Soviet-trained personnel.

55. See Horiuchi (1999) for details. 
The government responded in two ways. First, the February 1943 Outline of Emergency Measures for Price Controls organized a system whereby the government would raise producer prices through subsidized spending. Thus, market forces were allowed back into the system, though in a very restricted way. Second, the Munitions Corporation Law of 1943 required each company to have one "responsible person" who was to be "accountable" for the company's achieving its production quota. All workers had an unconditional duty to obey all orders of the responsible person. Thus, rather tougher corporate governance standards were established.

When the U.S. occupation force entered Japan in 1945, they thus entered a country that, though a former right-wing dictatorship, was nonetheless virtually as centrally planned as many Eastern European countries were in 1989. While economic historians sometimes write that the zaibatsu were dismantled and the banking system was reorganized under the U.S. occupation, this is perhaps an overstatement. The zaibatsu families had already lost control, and the banking system was already changed beyond recognition from its prewar structure. The issue of whether or not to destroy the prewar system was moot. The real question was whether to rebuild it as it had been or as something different.

\subsection{MacArthur Brings Anglo-American Capitalism to Japan}

General Douglas MacArthur, the supreme commander of the Allied powers (SCAP) and military governor of Japan under the U.S. occupation from 1945 to 1952, apparently shared his predecessors' suspicion of powerful business families. Certainly, zaibatsu companies increased their market power during the war and played important roles in providing military equipment and supplies to the Imperial Army. ${ }^{56}$ However, the zaibatsu families' involvement in these activities remains unclear. Although no fan of socialism, MacArthur let a cadre of New Dealers introduce SCAP economic policies aimed at dismantling the zaibatsu. ${ }^{57}$ Prominent among these efforts were the reorganization of the banking industry and the restructuring of former zaibatsu member firms as freestanding widely held firms of the sort that had recently replaced pyramidal groups under the new Deal in the United States. ${ }^{58}$ Hostile takeovers and greenmail ensued under Japan's brief, but action-packed, adventure in Anglo-American corporate governance.

56. See Yafeh (2000).

57. Dower (2000) describes MacArthur's orchestration of anti-Communist purges, his vast antired censorship system, and his distinctly right-wing approach to dealing with unions.

58. The New Deal broke up pyramidal groups in the United States by subjecting intercorporate dividends to taxes and by proscribing intercorporate ownership in public utilities. See Becht and DeLong (chap. 11 in this volume) and Morck (2005) for details. 


\subsubsection{The Agenda of the Supreme Commander of the Allied Powers}

Following World War II, the U.S. occupation oversaw a full-scale revamping of Japan's corporate and financial systems along the lines of the U.S. systems. This revamping, while immensely complicated, has two key elements that relate to the topic at hand. Both were copies of reforms enacted in the United States under Roosevelt's New Deal.

First, banks could no longer underwrite securities, as in the United States under the Glass Steagall Act of 1933, a key plank of the New Deal. Although the U.S. government exerted considerable pressure for a complete ban on bank ownership of nonfinancial firms' stock, along the lines of U.S. practice, the Allied forces ultimately decided against this. Banks' share ownership in other companies was limited to 5 percent stakes. This effectively prevented banks from being situated near the apex of a pyramid. Nevertheless, banks remained equity blockholders in their clients and other firms. ${ }^{59}$

Second, MacArthur permanently broke up large pyramidal groups, as Roosevelt did in the United States via the New Deal. Despite the military's usurpation of corporate governance power, the zaibatsu families' shareholdings remained on the books. In 1950, MacArthur ordered their shares confiscated, all intercorporate blockholdings unwound, and the senior executives of zaibatsu firms purged.

The primary reasons the SCAP used to justify the breakup of the zaibatsu was their alleged market power. Thus, the Department of State and the War Department jointly reported in 1946 that

The almost complete zaibatsu control of banks and financial institutions prevented independent businesses from getting needed financing; zaibatsu-controlled distribution systems could cut off the supply of raw materials and supplies needed by independent businesses entirely; similarly, selling independent business's [sic] finished products outside strictly local markets required the cooperation of the zaibatsu trading houses, which largely controlled Japan's distribution systems; and zaibatsu firms were able to cripple small firms by pirating their key employees and skilled workmen. These practices, and the independents' respect for not violating zaibatsu's territories, prevented meaningful competition from existing in Japanese markets.

The SCAP seemed intent on removing barriers to entry for political as well as economic reasons. The revamping it supervised was clearly intended to democratize the economy and encourage a new cadre of entrepreneurs. Hadley (1970, p. 19) writes that

59. This let banks become major players in the postwar horizontal keiretsu, a unique Japanese form of industrial organization that emerged after the U.S. withdrawal. 
the aim of the Allied economic deconcentration program was to give all Japanese businessmen the opportunity to engage in the modern sector of the economy, that is, to remove those conditions which preserved this sector for chosen few, those conditions which in fact made it a private collectivism.

Whether zaibatsu would have exercised an unhealthy degree of market power in a free-market postwar economy is academic. Certainly, their market shares had grown substantially in the 1930s and 1940s under the controlled economy. Historically, Japan always had some sectors in which competition was keen and entry open. However, especially after the demise of the Suzuki zaibatsu, the remaining large pyramidal groups came to hold substantial market shares in many key industries, as shown in table 7.5. The central planners of the military government had little interest in entrants and preferred directing the affairs of large companies. Dealing with many companies instead of a few simply made the transmission of orders more complicated.

\subsubsection{The Incomplete Process of Zaibatsu Dissolution}

To implement MacArthur's order to "dissolve large industrial and banking combines," the Japanese government established the Holding Company Liquidation Commission (HCLC). The HCLC designated ten combines and eighty-three holding companies for dissolution. The zaibatsu core families and their relatives were ordered to surrender their shares in exchange for ten-year nonnegotiable government bonds. ${ }^{60}$ Thus, no property was formally confiscated without compensation. Indeed, the old shareholders initially appeared generously compensated for their property. However, the subsequent inflation made the government bonds almost valueless.

The hired managers of zaibatsu companies, many of whom were competent, were purged by the SCAP. This probably created a shortage of able managers that persisted at least through the early 1950s. More extensive purges in zaibatsu than in other firms might explain Yafeh's (1995) finding of poorer accounting performance by former zaibatsu firms in 1953. This could also explain depressed values for these same firms, as reported by Miyajima (1994, table 10). After the occupation ended in 1952, many purged managers returned in various capacities.

In contrast to the purgings of corporate executives, Noguchi (1998) reports that Japanese bureaucrats were, to a large extent, untouched. While

60. Tamaki (1976, p. 453) records that the HCLC redistributed about 166 million shares, nominally worth $¥ 7.6$ billion in paid-in capital, from these holding companies and fifty-six zaibatsu family individuals. The firms designated for dissolution constituted about 42 percent of the paid-in capital of the corporate sector, or about $¥ 18.4$ billion. 
21,000 managers were purged from other sectors of Japanese society, only 2,000 bureaucrats, mostly from the Ministry of the Interior, were chucked. Most notably, only nine bureaucrats of the Ministry of Finance were purged. This was important, for the Ministry of Finance worked to alter or circumvent SCAP orders regarding many policy matters, often aggressively. Indeed, Hadley (1970, p. 15) mentions the deep puzzlement the U.S. personnel involved in this policy felt at the support business groups, individuals, and Japanese government officials provided for this interference. Overall, the implemented zaibatsu dissolution policies left considerable wiggle room for the Japanese government to permit business interests to organize new business groups along the lines of former zaibatsu groups.

For example, we noted above that several alternative definitions of zaibatsu are advanced by Japanese and foreign students of the Japanese economy. This ambiguity also affected the non-Japanese personnel supervising the postwar revamping of the economy, and may have been in part responsible for the less than complete implementation of the original dissolution plan. Thus, the HCLC decided not to disassemble the small group built around Japan Nitrogenous Fertilizer Company, the Nippon Chisso Hiryo zaibatsu, because its founder died in 1944 and it was therefore not really a zaibatsu (Hadley 1970, p. 21).

The SCAP used market share as the primary determinant of whether a zaibatsu was in need of dissolution. This had several odd effects. For example, the banking sector, in which no single bank held a clearly dominant market share, was left relatively untouched throughout the occupation, save that banks had to disgorge their shares in nonfinancial companies in excess of 5 percent stakes. Many pyramidal structures in nonfinancial sectors also remained in place and were carried over to the postwar era in the formation of vertical keiretsu, also called capital keiretsu.

Confronted with a deepening cold war and the rising influence of the Soviet Union in the Pacific, policymakers in Washington deemphasized MacArthur's restructuring plans and sought to reconstruct Japan as rapidly as possible to defend the region jointly with the United States. ${ }^{61}$ The HCLC was thus left to its own interpretation of its orders.

\subsubsection{The Subsequent Stock Market Collapse}

The SCAP closed Japan's stock exchanges in September 1945 and reopened them on May 16, 1949. Table 7.16 shows the de jure shareholdings of the Mitsui, Mitsubishi, Sumitomo, and Yasuda zaibatsu in 1945. The SCAP transferred these shares, and most other intercorporate block holdings, to employees and other assigned investors. Employees and other se-

61. This policy shift actually became evident when Ridgeway succeeded MacArthur in mid1950, well before the end of the occupation of Japan in April 1952. 


\begin{tabular}{|c|c|c|c|c|c|c|}
\hline \multirow[b]{2}{*}{ Zaibatsu } & \multirow[b]{2}{*}{ Firms } & \multirow[b]{2}{*}{ Shares } & \multicolumn{4}{|c|}{ Percent stakes of zaibatsu parties } \\
\hline & & & Family & Apex firm & First-tier firms & Total \\
\hline Mitsui & 1 & 10,000 & 63.6 & & 0.9 & 64.5 \\
\hline First-tier firms & 10 & 17,979 & 9.5 & 53.9 & 11.9 & 75.3 \\
\hline Second-tier firms & 13 & 9,038 & 0.0 & 35.9 & 17.2 & 53.1 \\
\hline Mitsubishi & 1 & 4,800 & 47.8 & & 10.8 & 58.6 \\
\hline First-tier firms & 11 & 41,234 & 1.4 & 28.9 & 15.3 & 47.5 \\
\hline Second-tier firms & 16 & 8,053 & 0.2 & 18.2 & 40.3 & 58.7 \\
\hline Sumitomo & 1 & 600 & 83.3 & & 16.7 & 100.0 \\
\hline First-tier firms & 17 & 34,312 & 8.4 & 19.5 & 16.6 & 44.5 \\
\hline Second-tier firms & 6 & 5,325 & 0.5 & 12.7 & 30.7 & 43.9 \\
\hline Yasuda & 1 & 300 & 100.0 & & & 100.0 \\
\hline First-tier firms & 20 & 9,469 & 3.5 & 24.3 & 17.8 & 45.6 \\
\hline Second-tier firms & 12 & 3,860 & 0.1 & 16.9 & 15.3 & 32.3 \\
\hline
\end{tabular}

Sources: HCLC (1950), Ministry of Finance (1983)

lect groups could buy these shares at very low prices, and in many cases the shares were virtually or actually given away. ${ }^{62}$ This greatly diluted the equity of many of the companies involved and sharply reduced their share prices. Because the larger zaibatsu contained the most extensive crossholdings, instances where subsidiaries also hold stock in their parent companies or in which subsidiaries hold stock in each other, the impact of this dilution was especially severe in those firms.

Figure 7.10 explains the dilution effect and assumes for simplicity that the intercorporate equity blocks were simply given to employees or other favored investors. The upper panel shows a cross-holding arrangement, common within pyramids. The family-controlled Firm A owns one million shares in its subsidiary, Firm B, but B in turn owns one million shares in the parent Firm A. Each lists its shares in the other as assets and its div-

62. Tamaki (1976, p. 454) records that the HCLC sold about 23 percent of holding companies' and zaibatsu families' former shares to employees. The rest were sold through a variety of general, special, and regional auctions, via underwriters or to trust accounts. Employees could each buy up to $¥ 30,000$ of shares at deeply reduced prices, and each manager could buy up to 1 percent. Employees and executives typically cashed out when the stock markets reopened in 1949. For example, Mitsui Bussan, prior to its dissolution, had 7,050 employees. Many of these workers, who lost their jobs after the dissolution, used the cash so raised to set up new companies to take over their former employers' business. The SCAP prohibited any new company from employing more than 100 workers, not including executives, who formerly worked for either Mitsui Bussan or Mitsubishi Corporation, and prohibited any new company from involving in any way more than one person who was a manager of any rank, consultant, or executive of either Mitsui Bussan or Mitsubishi Corporation. Former employees of Mitsui Bussan are thought to have set up as many as 220 small companies to take over former Mitsui Bussan business while satisfying the legal requirement. The corresponding figure for the Mitsubishi Corporation was 140. 
Panel A. Prior to Dissolution

Apexfirm

\begin{tabular}{|c|c|c|}
\hline \multicolumn{3}{|c|}{ Firm A } \\
\hline \multirow[t]{2}{*}{ Assets: } & $\begin{array}{l}¥ 100 \text { million } \\
¥ 100 \text { million }\end{array}$ & $\begin{array}{l}\text { Real assets } \\
\text { Shares of B }\end{array}$ \\
\hline & $¥ 200$ million & Total \\
\hline \multirow[t]{2}{*}{ Income: } & $\begin{array}{l}¥ 10 \text { million } \\
¥ 10 \text { million }\end{array}$ & $\begin{array}{l}\text { Operating Income } \\
\text { Dividends from B }\end{array}$ \\
\hline & $¥ 20$ million & Total \\
\hline \multirow[t]{5}{*}{ Shares: } & $¥ 100$ & Price per share \\
\hline & $¥ 10$ & Dividend per share \\
\hline & 1 million & Owned by family \\
\hline & 1 million & Owned by Firm B \\
\hline & 2 million & Total \\
\hline
\end{tabular}

Publicly traded subsidiary

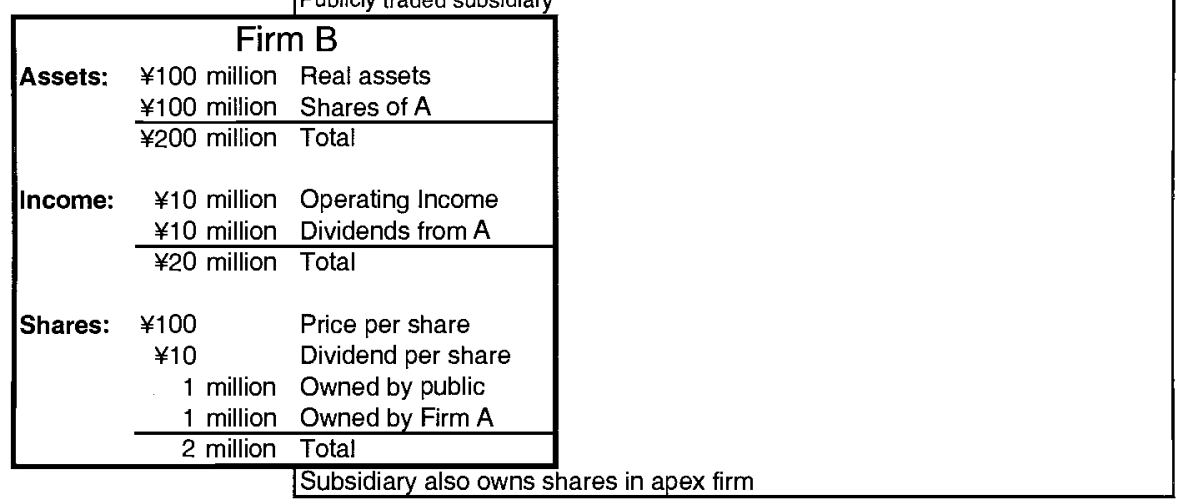

Panel B. After Dissolution

\begin{tabular}{|c|c|c|}
\hline \multicolumn{3}{|c|}{ Firm A } \\
\hline \multirow[t]{2}{*}{ Assets: } & $¥ 100$ million & Real assets \\
\hline & $¥ 100$ million & Total \\
\hline \multirow{2}{*}{ Income: } & $¥ 10$ million & Operating Income \\
\hline & $¥ 10$ million & Total \\
\hline Shares: & $\begin{array}{l}¥ 50 \\
¥ 5 \\
2 \text { million }\end{array}$ & $\begin{array}{l}\text { Price per share } \\
\text { Dividend per share } \\
\text { Owned by public }\end{array}$ \\
\hline
\end{tabular}

\begin{tabular}{|c|c|c|}
\hline \multicolumn{3}{|c|}{ Firm B } \\
\hline \multirow[t]{2}{*}{ Assets: } & $¥ 100$ million & Real assets \\
\hline & $¥ 100$ million & Total \\
\hline \multirow[t]{2}{*}{ Income: } & $¥ 10$ million & Operating Income \\
\hline & $¥ 10$ million & Total \\
\hline \multirow{3}{*}{ Shares: } & $¥ 50$ & Price per share \\
\hline & $¥ 5$ & Dividend per share \\
\hline & 2 million & Owned by public \\
\hline
\end{tabular}

Fig. 7.10 How cross-holdings affect the value of shares upon zaibatsu dissolution

idends from the other as income, so each has assets and income twice what would be the case were they freestanding firms. Since each has $¥ 200$ million in assets and two million shares outstanding, both firms' shares are worth $¥ 100$.

The lower panel shows what happens after dissolution of the sort implemented in Japan by the HCLC. The shares previously held by the zaibatsu family and the cross-holdings are appropriated by the HCLC and sold to 
New share issues, 1948-53

\begin{tabular}{lrrrrrr}
\hline & 1948 & 1949 & 1950 & 1951 & 1952 & 1953 \\
\hline (A) Number of new shares issued & 50,094 & 78,718 & 39,192 & 83,644 & 123,336 & 91,569 \\
(B) Percent of (A) issued to finance & & & & & & \\
$\quad$ restructuring & 30.5 & 17.0 & 5.6 & 0.3 & & \\
(C) No. of shares released by HCLC & & & & & & \\
$\quad$ for zaibatsu dissolution purposes & 40,317 & 39,711 & 854 & 996 & & \\
(D) Average price per share & & 128.85 & 74.00 & 93.8 & 124.06 & 156.05 \\
(E) Stock return (\%) & 4.02 & 4.65 & 6.61 & 7.99 & 8.02 & 7.96 \\
(F) Excess return above interest rate & -4.80 & -4.96 & -2.47 & -1.22 & -1.03 & -0.85 \\
\hline
\end{tabular}

Source: Miyajima (1994).

Notes: Figures in rows (A), (C), and (D) are for 1,000 shares.

other shareholders. ${ }^{63}$ The funds so raised are kept by the government. None of the proceeds go to either Firm A or Firm B. Thus, the only assets in both are now their physical assets, and their only incomes are now their operating incomes. Yet the number of shares outstanding has not declined proportionately. Consequently, share prices of both firms fall by 50 percent.

Cross-holdings of this sort were commonplace. For example, 64 percent and 59 percent of the outstanding shares of the apex companies of the Mitsui and Mitsubishi zaibatsu, respectively, were owned by Mitsui and Mitsubishi subsidiaries. The holding companies of both the Sumitomo and Yasuda zaibatsu were actually entirely owned by their respective zaibatsu subsidiaries. Thus, stock prices plunged as the dissolution was announced and as the value of the bonds issued as compensation dropped.

Share prices in the immediate postwar period were also depressed because of the extensive damage the war had inflicted on the physical assets of industrial firms. To begin rebuilding, firms issued more new shares, adding these to the former zaibatsu control block shares flooding the market. The SCAP also ordered the government to suspend the promised payments to munitions suppliers to prevent these firms from profiting off their wartime activities. The Corporation Reconstruction and Reorganization Act of 1946 allowed firms bankrupted by the nonpayment of wartime indemnities to resume operations as "special account companies" and also allowed firms' net losses due to official nonpayment to be written off (Hoshi 1995). Average paid-in ratios of capital to total assets fell to 10 percent by 1950 (Ministry of Finance 1983). Finally, Yafeh (2004) argues that the population of potential investors was impoverished and probably highly risk averse. They consequently rapidly sold the shares the SCAP assigned them to finance consumption and low-risk savings. Table 7.17 
shows the numbers of new shares issued, as well as the shares brought to the stock market by the HCLC for sale. The shares HCLC brought to the market amounted to 30 percent of the newly issued shares in 1948, 17 percent in 1949, 5.6 percent in 1950, and 0.3 percent in 1951.

It is clear that the shares freed by the zaibatsu dissolution order had a major impact on the overall stock market. Although non-zaibatsu firms suffered smaller stock price declines because their shares were not diluted, their stocks nonetheless fell as the total amount of equity available to the public rose. Thus, new shares issued by firms like Toshiba and Hitachi fetched low prices.

Several economic measures were introduced in 1949 to stabilize the Japanese economy. These included fixing the exchange rate and suspending new loans from the Reconstruction Financing Bank. The latter policy reduced the supply of funds available to Japanese industry, increased interest rates, and induced even more firms to issue equity. This, on top of the other factors listed above, triggered a collapse of the Japanese stock market. Table 7.18 shows the drop in stock prices from 1949 to 1950. These stock price fluctuations are also evident in the ratios of price to capital stock and market to book, shown in table 7.19.

Over the next few years, firms shied away from further diluting their equity by issuing shares at the prices prevailing. During the period 1950-54, new issues accounted for less than 20 percent of Japanese industrial firms'

Table 7.18

Tokyo Stock Exchange price index

\begin{tabular}{lcccc}
\hline & 1949 & 1950 & 1951 & 1952 \\
\hline Low & 98.50 (December) & 85.25 (July) & 102.20 (January) & 167.80 (January) \\
High & 176.88 (September) & 114.99 (August) & 170.20 (October) & 370.56 (December) \\
\hline
\end{tabular}

Table 7.19

Price-capital stock and price-equity ratios for Mitsui, Mitsubishi, and Sumitomo zaibatsu firms, 1949-53

\begin{tabular}{lcccccc}
\hline Zaibatsu & Ratio & 1949 & 1950 & 1951 & 1952 & 1953 \\
\hline Mitsubishi & W/K & 1.61 & 0.46 & 0.39 & 0.72 & 1.00 \\
& W/E & 2.43 & 0.68 & 0.45 & 0.75 & 0.97 \\
Sumitomo & W/K & 1.96 & 0.34 & 0.35 & 0.78 & 0.86 \\
& W/E & 3.22 & 0.34 & 0.31 & 0.68 & 0.77 \\
Mitsui & W/K & 0.91 & 0.27 & 0.27 & 0.45 & 0.57 \\
& W/E & 1.71 & 0.34 & 0.44 & 0.75 & 0.80 \\
\hline
\end{tabular}

Source: Miyajima (1994).

Notes: $\mathrm{W}=$ average share price; $\mathrm{K}$ = fixed capital stock (book value); $\mathrm{E}=$ stockholders' equity set equal to (total assets [book value] - total debt [book value]). The numbers of firms included for Mitsubishi, Sumitomo, and Mitsui groups are 15, 8, and 12, respectively. 
external financing. Short-term bank debt was now becoming the main source of corporate financing.

By the end of the occupation, Japan was an Anglo-Saxon economy, in that its major firms were freestanding and widely held. The number of shareholders rose from 1.7 million in 1945 to 4.2 million in 1950 . The zaibatsu dissolution by SCAP massively redistributed the stocks of Japanese corporations. ${ }^{64}$ The shares transferred from the zaibatsu families to the public by the HCLC amounted to over 40 percent of all corporate assets in Japan. The consequence was a widely diffused ownership of much of the Japanese corporate sector, with individual shareholders holding 70 percent of the outstanding shares of typical Japanese corporations in 1949 and 1950 (Bisson 1954).

\subsubsection{The New Legal Framework for Shareholders}

The SCAP also supervised the enactment of new laws that would shape Japan's future business activities.

The Anti-Monopoly Law of 1947 was actually also an antipyramid law. It prohibited the establishment of holding companies, 25 percent or more of whose asset base consists of the stock of other firms; manufacturing firms' owning the stock of other firms; and financial institutions' owning more than 5 percent of other firms. Subsequently, this law was frequently amended in response to corporate lobbying.

An amendment in 1949 allowed manufacturing firms to own other firms, permitting the formation of vertical (capital) keiretsu, in which large manufacturers partly own other manufacturers. A 1953 amendment increased the limit of banks' ownership of industrial firms from the original 5 percent to 10 percent. This 10 percent limit was reduced to 5 percent again in 1987 . For most practical purposes these limits had never been a barrier for Japanese banks intent upon exercising corporate governance power over their client firms, particularly those under financial distress. Banks often voted additional shares through controlled financial subsidiaries, like insurance and trust companies.

The Securities Trading Act of 1948 was designed to protect small shareholders. An auditor system was also established in 1948, followed by a set of corporate accounting principles in 1950. In 1951, new depreciation rules ended firms' freedom to determine their own depreciation rates and methods. These initiatives were significant, for prewar Japan had no serious shareholder rights, accounting standards, auditing procedure rules, public disclosure rules, or depreciation rules. ${ }^{65}$

64. Some authors have found some analogy between this historical event and more contemporary privatization of government-owned corporations. See, e.g., Yafeh (1995).

65. See Miyajima (2000). 
The Japanese commercial code was also revised in 1950 to give small shareholders rights to access company books and records and to establish fiduciary duties of directors to shareholders. However, the government defined a small shareholder as one with at least 5 percent equity ownership. In subsequent years, Japanese banks intervening in their client firms' management often used this rule.

\subsubsection{The Keiretsu Defense}

An active market for corporate control developed quickly. Hostile takeover bids became high-profile events, and several were launched against former zaibatsu firms - including Taisho Marine and Mitsui Real Estate. ${ }^{66}$ As in the United States and Britain, the possibility of a hostile takeover appears to have a governance impact greatly out of proportion to the actual frequency of these events. ${ }^{67}$ In response to this threat, the managers of firms from each former zaibatsu began to act as a group-coordinating white knight and white squire defensive arrangements to protect their former affiliated companies from hostile takeovers.

In the white knight defense, the target of a hostile bid arranges to be taken over instead by a friendly company that safeguards the positions of the target's top executives. In the white squire defense, the target arranges for a friendly company to purchase temporarily a large enough block of target stock to prevent the hostile takeover from succeeding.

These coordinated actions were possible because top managers constructed postwar analogs to the family councils that coordinated zaibatsu affairs prior to the war. Thus, former Mitsubishi firms' presidents began having regular Friday luncheon meetings in June 1946, immediately after the Mitsubishi family council was formally abolished. The Sumitomo group began their presidents' council in 1949, and the presidents of the former Mitsui companies formed their presidents' club around 1950. Subsequently, these regular meetings of the presidents of former zaibatsu companies all came to be called presidents' clubs.

Hideki Yokoi was one of the best-known corporate raiders in postwar Japan. Yokoi became wealthy from dealings with MacArthur's general headquarters (GHQ) and, allegedly, in the black market created by prewar and wartime price controls. With a huge cash hoard, Yokoi launched takeovers of company after company.

In 1953 he purchased more than 40 percent of the outstanding shares of Shirokiya, a department store company. ${ }^{68}$ Yokoi then organized a general

66. For details of some notable Japanese takeovers and takeover defenses at this time, see Sheard (1991) and Miyajima (1994).

67. See Morck, Shleifer, and Vishny (1988a,b, 1989) regarding hostile takeovers in the United States and Franks, Mayer, and Rossi (chap. 10 in this volume) regarding the United Kingdom.

68. Its major property is now a part of the Tokyu department store in Nihonbashi. 
stockholders' meeting, at which he won control of the board. Shirokiya sued Yokoi, and four days later Yokoi lost control of the company. Yokoi had to ask Keita Goto, then the chief executive officer (CEO) of Tokyu, for mediation. Yokoi (1960) reflected on the benefit of his takeover to Shirokiya, noting that

I sacrificed myself to do the best for Shirokiya which now is in such great shape; without my takeover and the following business intervention by Keita Goto of the Tokyu group, Shirokiya would have been unable to increase its capacity and would have either become a third-rate department store or an office building, closing its 300-year history. (quoted in Sataka 1994, p. 35)

Yokoi continued launching corporate takeovers over the following two decades. After Shirokiya, he mounted raids on Toa Oil, Daikyo Oil, Imperial Hotels, Tokai Shipping Line, Toyo Sugar, Shibaura Sugar, Taito Sugar, Dainippon Sugar, and many other companies. He died in 1998 at the age of eighty-five.

A pivotal event in the development of the Anglo-American system in Japan was the raid by Kyujiro Fujinami against Youwa Properties. By 1952 Fujinami, by then a well-known corporate raider, had purchased 250,000 of the 720,000 outstanding shares of Youwa Properties, a company that had managed landholdings and other properties for the Mitsubishi group. Fujinami, a former security guard at the Tokyo Stock Exchange, demanded seats on the board of Youwa. The Mitsubishi Bank, together with the companies run by other members of the Mitsubishi Presidents' Council, offered to pay greenmail and buy back all the shares Fujinami had acquired at a price of $¥ 1600$ per share, well above the market price of $¥ 240$. This coordinated action was necessary because Japanese law prohibited firms from repurchasing their own stock. Youwa thus could not pay its own greenmail. Mitsubishi group firms each bought a small block of shares from Fujinami to avoid contravening the Anti-Monopoly Law of $1947 .{ }^{69}$

This event is thought to have triggered the realization by top executives that corporate raids could be blocked by establishing sufficiently large crossholdings among former zaibatsu firms. If each former Mitsubishi zaibatsu firm owned a little stock in every other former Mitsubishi zaibatsu firm, the members of the Mitsubishi presidents' club could collectively vote control blocks in every former Mitsubishi firm. These firms would then all be safe from hostile takeovers, the need to pay greenmail would disappear, and the company presidents would have secure tenure in their jobs.

This keiretsu defense is a variant of the white knight or white squire defense. In the keiretsu defense, a cadre of friendly companies each take a small position in the target such that these positions, taken together, add

69. Subsequently, in 1953 Mitsubishi Estates, Mitsubishi's main land development company, absorbed both Youwa and another Mitsubishi realtor, Kantou Properties. 
up to a control block sufficient to deter a hostile takeover. Evidence from the United States suggests that modest white squire positions can deter raiders. Morck, Shleifer, and Vishny (1988b) argue that managementaffiliated blocks as small as 5 percent can deflect raids because they give insiders a head start in any race to accumulate shares. La Porta et al. (1999) show that intercorporate stakes of 10 percent confer control rights in zaibatsu-like pyramidal groups in many countries. Yafeh (2004) summarizes data on such intercorporate holdings in postwar Japan and shows them to be in this range or higher.

\subsection{Self-Assembling Keiretsu}

Japan's postwar keiretsu formed in two waves. In both, defenses against corporate takeovers appear to have been the primary motive. ${ }^{70}$ The first wave, discussed above, took place in the 1950s and involved the selforganization of keiretsu comprising the former member firms of the old Mitsui, Mitsubishi, and Sumitomo zaibatsu. The second wave, in the 1960s, saw the self-organization of three new horizontal keiretsu. The Fuji Bank helped organize the Fuyo keiretsu by orchestrating a network of intercorporate share placements. Simultaneously, the Sanwa Bank helped construct the Sanwa keiretsu, and the Daiichi Kangyo Bank (DKB) helped assemble the Dai Ichi Bank keiretsu. In both cases, the banks apparently sought to insulate the managers of their client firms from hostile takeovers.

Each keiretsu firm has a "main securities firm" or kanji gaisha, with which it has a long-term relationship. These kanji gaisha usually hold the group's cross-holdings equity certificates in their vaults. Thus, one firm cannot sell its cross-holdings in another without notifying the kanji gaisha, which then notifies the other firm. Hence, there is a credible promise to be a "stable shareholder." 11

Recent work by Miwa and Ramseyer (2002) contests much of the praise for Japan's keiretsu by students of corporate strategy, such as Porter (1990). While we concur that much laudatory discussion of the "Japanese Model" in the 1980s is problematic, we do not agree with the contention of Miwa and Ramseyer that keiretsu are fables. ${ }^{72}$ Morck and Nakamura (1999) doc-

70. Yafeh $(1995,2000,2004)$ argues more generally that poor performance caused firms to reconfigure their ownership structure. Since takeovers and the keiretsu takeover defense are both instances of ownership structure reconfiguration and Morck, Shleifer, and Vishny (1988a,b, 1989) argue that poor performance invites hostile takeovers, this argument is not inconsistent with ours.

71. See Sheard (1994).

72. Note also that Gerlach (1992), Lincoln, Gerlach, and Takahashi (1992), Lincoln, Gerlach, and Ahmadjian (1996), and other quantitative sociologists typically find that keiretsu connections are important in unconditional multivariate data analysis. See Aoki (1988) and Kojima (1997) for a detailed analysis of how Japanese corporate governance was thought to differ fundamentally from that elsewhere. Many of Aoki's points have not been refuted. 
ument a clear pattern of repeated bailouts of weak keiretsu firms, but not of otherwise similarly troubled independent firms. Keiretsu firms - and especially keiretsu main banks - were remarkably successful at shaping Japanese institutions to their advantage. Keiretsu are a genuinely important feature of postwar Japan, but their role is primarily to entrench top corporate management and to safeguard a monotonous stability in Japan's list of leading corporations. ${ }^{73}$

Modern Japanese keiretsu divide into two genres: horizontal keiretsu and vertical keiretsu.

\subsubsection{Horizontal Keiretsu}

As noted above, takeover defense arrangements led to groups wherein member firms were controlled collectively by all the other firms in the group through a multitude of small equity stakes. These groups, called horizontal keiretsu, recreated for their member firms' top managers the freedom from outside shareholder pressure the zaibatsu had provided. Moreover, since no family holding company exercised control, horizontal keiretsu also freed top managers from oversight by a controlling shareholder. Thus, member firms of the keiretsu of postwar Japan were similar to the widely held firms described by Beale and Means (1932), for their top managers were accountable only to themselves.

But horizontal keiretsu took the Beale and Means firm a step further. Because a majority of their companies' stock was in the hands of white squires, or stable investors, the managers of keiretsu member firms had no need to fear corporate raiders, proxy contests at shareholder meetings, or institutional investor pressure. They were truly free to run their firms as they saw fit, without regard for share value, profits, or dividends. Keiretsu top managers were thus more insulated from shareholder pressure that was possible in even the most widely held firm.

Figure 7.11 illustrates a stylized horizontal keiretsu. The intercorporate stakes involved are each individually quite small, so that each firm looks superficially as if it were widely held. However, only a minority of the stock in each of the companies is left available to public shareholders and thus to potential raiders.

As rules against pyramids were relaxed after the U.S. withdrawal, core keiretsu member firms began establishing new pyramids, with themselves at the apex. Thus, horizontal keiretsu in contemporary Japan are best thought of as clusters of core firms, each of which controls its own pyramid of publicly traded subsidiaries in a substructure akin to a prewar widely held zaibatsu. It is only the core firms that collectively control a majority of each other's shares through a dense network of individually tiny intercorporate equity blocks. 




Fig. 7.11 A stylized diagram of a post-World War II horizontal keiretsu

Notes: Large circles represent core member firms of the keiretsu, which hold small blocks of stock in each other that collectively sum to control blocks. Each core keiretsu firm holds control blocks of lesser keiretsu member firms, indicated by small circles, and many of these sit at the apex of their own pyramid of such firms. For simplicity, only one such nested pyramid is shown.

\subsubsection{Vertical Keiretsu}

A second genre of keiretsu, called vertical keiretsu, exhibits a more classically pyramidal structure. Some are simply industrial zaibatsu that escaped dissolution. These include Shibaura Manufacturing Works (now Toshiba) and Hitachi, Ltd. Shibaura was a second-tier member of the Mitsui zaibatsu and the most important prewar electric appliances manufacturer. In 1939, it spun off twelve supplier firms and acquired control blocks in eight other companies with which it had close customer-supplier relationships. Toshiba executives also served as directors of these companies. ${ }^{74}$ Hitachi was part of the Nissan zaibatsu. By 1937 it had set up its own vertically integrated group with nine supplier companies within the Nissan group. ${ }^{75}$ Many of these

74. Tamaki (1976, pp. 154-55) describes Toshiba's relationships with these firms in more detail.

75. See Tamaki (1976, p. 399). 
Toshiba and Hitachi suppliers still exist and are now members of their respective vertical keiretsu.

However, the ranks of vertical keiretsu also contain new groups. These arose after the war in certain manufacturing industries, like automobiles and electric appliances, where product assembly was divisible into discrete steps, each to be carried out by a separate firm. Again, white squire takeover defenses were probably key to their original formation.

Vertical keiretsu are more pyramidal than horizontal keiretsu. An apex firm holds control blocks in a first tier of key suppliers. Each holds control blocks in its suppliers, which hold control blocks in yet another tier of suppliers, and so on.

Despite their similarity to prewar industrial zaibatsu, some differences justify a new term. Unlike industrial zaibatsu, vertical keiretsu also feature dense fogs of small intercorporate equity stakes of any number of member firms in each other, much as in horizontal keiretsu. For example, Toyota Motors owns controlling blocks in the range of 15 to 30 percent in each of its main parts suppliers. Nonetheless, only a minority of the stock in these suppliers is available to public investors, for holdings by other members of the Toyota keiretsu raise the total stakes of stable shareholders above 50 percent in each case. Still, as in a prewar zaibatsu, the Toyoda family has substantial control over Toyota Motors itself. ${ }^{76}$ Some of the Toyota keiretsu firms are spin-offs from Toyota Motors or from other older keiretsu member firms. Others are independent firms that find it advantageous to cement their alliances to Toyota by selling control blocks to Toyota firms, and so joining the Toyota keiretsu.

Another important difference is that the apex firm in an industrial zaibatsu clearly directed activities in all the member firms of the pyramid. In contrast, vertical keiretsu firms are alleged only to coordinate decision making with the firms directly above and directly below them in the pyramid. This decentralized planning is said to be possible because the integration in vertical keiretsu is much tighter, with no superfluous firms that are not direct parts of the production chain leading to the final products of the apex firm. Industrial zaibatsu, in contrast, often contained firms whose activities were disjoint from their main production chains, and even firms in entirely unrelated industries.

\subsubsection{Other Firms}

Some prewar local zaibatsu survive in various forms, having escaped the notice of the SCAP and the HCLC. Some are even controlled by their prewar controlling families. One example is the Ito group of Nagoya, which continues to run Matsuzakaya department stores. Others are the Katakura

76. As discussed above, Toyota Motors was itself spun off from Toyota Jido Shokki, a loom maker. 
group of Nagano, whose Katakura Industries remains important in textiles; the Yasukawa group of Fukuoka, whose Yasuoka Electric remains a major electric appliance maker; and the Mogi group, based in Chiba prefecture, which controls Kikkoman, the soy sauce maker, and other firms. ${ }^{77}$

Finally, just as some firms in prewar Japan were not parts of zaibatsu, some firms in postwar Japan belong to no keiretsu. Some of these independents have prewar roots. For example, Masatoshi Ito built a small family clothing business founded in 1920 into Ito Yokado, the largest retail chain in Japan and owner of Seven-Eleven. Other essentially independent firms are entirely postwar phenomena. Prominent examples include Honda and Sony.

Firms represented in the presidents' clubs of the six major horizontal keiretsu-Mitsui, Mitsubishi, Sumitomo, Fuyo (formerly Yasuda), Sanwa, and Daiichi-Kangyo - employed only 4 percent of the total workforce of all nonfinancial listed firms in 1986-90 but owned in 199015 percent of their total assets (14 percent in 1986) and 17 percent of their total paid-in capital (14 percent in 1986). Also, in 1990, they owned 26 percent of the outstanding shares of all listed firms (24 percent in 1986), provided 37 percent of corporate debt of all listed firms (39 percent in 1986), and provided 45 percent of the directors of the boards of all listed firms throughout the period 1986-90 (Toyo Keizai 1991).

Independent Japanese firms are either private or narrowly held, usually with a founding family as the dominant shareholder. At present, Japan has no large widely held firms in the Anglo-American sense.

\subsubsection{More Definitional Ambiguities}

Like the term zaibatsu, the word keiretsu is deeply flavored with the characteristic Japanese taste for ambiguity. Deciding which, if any, keiretsu a firm belongs to is usually straightforward. However, there are cases where things become somewhat convoluted. For example, in addition to having its own vertical keiretsu, Toyota also belongs to the Mitsui keiretsu. Toyota's president attends meetings of the Mitsui presidents' club, and Toyota considers the Mitsui Bank its main bank, even though Toyota has no bank debt. Toyota participates in Mitsui-wide activities with other Mitsui firms, like Toshiba.

If one stretches the definition of a keiretsu somewhat, even independent firms like Sony and Honda have group ties. Thus, Sony is sometimes listed as a member of a "quasi-Mitsui group," as in Okumura (1976, p. 183), because of its ties and historical dealings with the Mitsui bank. The primary reason Sony is not explicitly a member of the Mitsui presidents' club seems to be that Toshiba is already a member, and each horizontal keiretsu contains only one company from each industry. This may be a holdover from the SCAP's concerns about high market shares. Likewise, Honda has extensive financial ties to the Tokyo-Mitsubishi Bank but does not belong to

77. See, e.g., Fruin (1983). 
Mitsubishi's presidents' club. Again, since Mitsubishi Motors belongs to the Mitsubishi presidents' club, there may be no room for Honda. Nevertheless, Honda is sometimes listed as a member of a "quasi-Mitsubishi" group, as in Okumura (p. 171).

By the end of the 1960s, the widely held firm had disappeared from the Japanese economic landscape. Japan's brief acquaintance with AngloAmerican corporate governance was over, and its current patterns of corporate ownership were essentially in place.

\subsubsection{The Former Zaibatsu Banks}

Banks were exempt from the SCAP's zaibatsu dissolution program because it deemed their market shares all acceptably low. However, the former zaibatsu families lost ownership of their zaibatsu banks-Teikoku Bank (a merger of the former Mitsui and Daiichi Banks), TokyoMitsubishi Bank, Sumitomo Bank, and Yasuda Bank.

The SCAP continued using the banks much as the military government had - assigning specific banks to "rubber-stamp" loans to selected strategically important firms. Thus, firms' "main banks" in the 1950s tended to be their "assigned banks" from the 1940s. Banks also won influence restructuring firms damaged by wartime losses. ${ }^{78}$ The shareholding culture of prewar Japan faded from collective memory, and banks assumed a leading role in the economy. ${ }^{79}$

The continuity of this role, and banks' ties to state planners, give rise to the so-called 1940s theory. This theory, due to Okazaki and OkunoFujiwara (1993) and Noguchi (1998), proposes that the current managed market economy originated in wartime Japan. ${ }^{80}$

Regardless, the SCAP's attitude toward long-term financial institutions was generally negative, and banks were proscribed from issuing bonds. In response to a perceived capital shortage in 1952, the year of the U.S. withdrawal, the government passed the Long-Term Credit Law, which permitted a new type of bank, the long-term credit bank, that could issue bonds but not take deposits. Other banks, thenceforth known as ordinary banks, could take deposits but not issue bonds. ${ }^{81}$ Three major new long-term credit banks formed: the Industrial Bank of Japan, the Japan Long-Term Credit Bank, and the Nippon Credit Bank. ${ }^{82}$

78. See Hoshi and Kashyap (2001) on the postwar continuation of the wartime system and on the banks' roles in postwar restructuring.

79. See Hoshi and Kashyap (2001).

80. See Hamada (1998) for a critique of this view.

81. At present, this structure of the Japanese banking system is the subject of considerable debate. There has already been a degree of reform, and further reforms would appear likely.

82. The IBJ, which practiced investment banking since 1900 under the Industrial Bank of Japan Act, became an ordinary bank in 1950 when the IBJ Act was repealed. The IBJ resumed its special status as an investment bank in 1952 when the new Long-Term Credit Bank Act was created. For details, see footnote 48. 
Most extant banks, including all the former zaibatsu banks, chose to be ordinary banks. This was because they had large established deposit and short-term lending businesses that generated significant profits before the war and looked set to do so again. By remaining ordinary banks, they could tap Japan's high household savings rate and lend to large corporations on a year-to-year basis. Despite their formal short-term structure, these loans were often really long term, in that they were rolled over indefinitely.

The former zaibatsu banks retained most of their prewar business relationships with their fellow former zaibatsu member firms and were referred to as the main banks of these client firms (Teranishi 1999). These networks of relationships were critical in the formation of the keiretsu in the 1950s and 1960s, for the former zaibatsu banks often organized the white squire equity placements that constitute the keiretsu.

This regulatory fragmentation of the Japanese banking system meant that main banks sometimes had inadequate capital to accommodate their largest clients' borrowing needs. In response, the Bank of Japan permitted syndicated loans.

Under the syndicated bank loan system, a large borrower's main bank took charge of organizing a syndicate of banks that could collectively meet the borrower's financing needs. The main bank apparently was expected to take a lead role in monitoring the borrower, to take charge of correcting any impending problems, and to take a disproportionately large hit in the event of a default..$^{83}$ This pattern continues in recent cases of defaulting firms, where the main bank becomes the "special manager" of a firm under reorganization.

Banks were thought to collect substantial private information about each other and about Japanese firms in general via syndicated lending, and to utilize this information to promulgate good corporate governance. However, Morck and Nakamura (1999), while documenting increased banker representation on the boards of troubled client firms, find no evidence consistent with corporate governance improvement. They argue that banks use their influence on boards primarily to maximize the value of their loan portfolios, and that this can deviate substantially from firm value maximization and economic efficiency. Hanazaki and Horiuchi (2004) go further, arguing that lax bank governance contributed to governance problems in other industries.

Japan's large banks also greatly affected the postwar development of the financial system. Bank lobbying is widely believed to underlie the Japanese government's ongoing and virtually complete suppression of the corporate

83. In contrast, Japanese banks did not usually get involved with rescue operations of distressed client firms prior to the early 1950s. Failing firms were simply liquidated. See Miyajima (1999). 
debt market until the 1990s. Corporate debt issues were forbidden unless fully backed by real property or explicitly approved by the government. Thus, what corporate bonds existed were little more than alienable mortgages. Debentures and other corporate debt securities were outlawed entirely.

The reason the banks took this route is fairly clear. They saw bonds as competition both for their depositors' money and their client firms' loans. Why the government accommodated their lobbying is less clear. The SCAP had promoted the stock market but largely ignored the corporate bond market. This may have reflected a lack of investor interest, for bondholders were badly hurt by the high postwar inflation. Also, the military government had used the banking system to carry out centrally planned capital allocation, so corporate bonds played little role in the wartime economy. Managers were not used to issuing debt. Still, the continued interdiction of corporate debt issues decades later raises puzzling political economy issues.

It is hard to escape the conclusion that the government and the banks worked to preserve market power for the country's major banks. Market power certainly derived from the barriers to competition the prewar and wartime regulators erected. Banks probably also held an informational advantage giving them a degree of market power over their clients, as in Rajan (1992). Whatever the precise nature of this market power, it corresponds to a period of great stability for the Japanese banking system. From the end of the war to 1997, no major bank failed and there were few bank mergers. While the strong regulatory hand of the Ministry of Finance may be partially responsible, such stability is certainly also consistent with prolonged bank market power.

Indeed, the two explanations are often intertwined in discussions of postwar Japanese banking. Thus, Hanazaki and Horiuchi (2003) write that

the primary purpose of the MOF's [Ministry of Finance's] administrative guidance was to suppress full-scale competition in each of the compartmentalized financial businesses. ... The government was able to utilize the rents accumulated in the banking sector as a means of dealing with banks in financial distress. Specifically, regulators relied on the cooperation of private banks in implementing the blanket guarantee, and major banks faithfully bore a disproportionate share of the costs involved. . . [B]y manipulating regulatory measures the MOF could do favors to those banks that towed [sic] the line and penalize those that failed to heed its guidance.

They argue that the Mitsubishi Bank, for example, got permission to pursue trust banking as a reward for rescuing Nippon Trust. Moreover, the view that banks transferred the financial value of keiretsu to themselves through such practices is consistent with the finding of Caves and Uekusa (1976) that 
group membership does not benefit industrial firms, and that any benefits must therefore be captured by nonindustrial firms - that is, banks.

Aoki (1994) argues that rents are necessary to motivate proper monitoring by banks. Hellman, Murdock, and Stiglitz (2000) argue that restricted competition is beneficial in that it reduces banks' incentives to maximize shareholder value by taking excessive risks in near-default situations. In contrast, Allen and Gale (2000) argue that competition is necessary to reveal which managers know what they're doing. Hanazaki and Horiuchi $(2000,2001)$ argue that such competition is responsible for the success of independent Japanese manufacturing firms and that its absence explains the weakness of keiretsu firms and the failure of its banks.

They argue that the international success of Japan's best firms undid this market power. By the 1980s, the country's most successful multinationals routinely issued debt abroad through their foreign subsidiaries. In response, the government relaxed the rules (somewhat) in the 1990s to allow firms whose financial ratios exceeded predetermined criteria to issue certain debt securities. ${ }^{84}$ This partial deregulation may have let Japan's best firms abandon bank loans and may have concentrated low-quality debt in the banking system. ${ }^{85}$ This argument, while probably true, does not explain the alacrity with which the more profitable firms abandoned bank loans as a source of capital. That the banks were extracting market power rents in the provision of capital would explain this rush for the exits.

\subsection{Lessons from the Well-Traveled Frog}

Japan's wide-ranging corporate governance history provides some insights into the value of corporate groups under different economic circumstances. Except under the military government, entrepreneurs (and querulous relatives) were free to start new firms. Since both zaibatsu and keiretsu formed spontaneously, survived, and prospered, they must have had some competitive advantage over new freestanding firms. There are several candidate explanations for this advantage. ${ }^{86}$

\subsubsection{Economies of Scope and Scale}

Corporate groups might exist because they are superior modes of corporate organization and so are good for the economy. Zaibatsu and keiretsu are clearly large enough corporate structures to capture a variety

84. See Morck and Nakamura (2001).

85. Aoki and Sheard (1992) and Hoshi, Kashyap, and Schaftstein (1993) show that the most financially sound firms switched to bond financing very quickly. Hellman, Murdock, and Stiglitz (2000) argue that this undermined the banking system. Boot and Thakor (2000) and Fraser, Ghon Rhee, and Shin (2002) both describe the importance of regulatory restraints on competition to relationship banking.

86. See also Yafeh (2003). 
of economies of scope and scale. However, the expansions of both did not seem driven by such economies. Zaibatsu remained tightly focused and of limited size until the mass privatizations at the turn of the twentieth century. Antitakeover defenses seem historically more important than economies of scale and scope in the formation of the keiretsu, especially the horizontal keiretsu. Despite their historical pedigrees, both might still have ended up capturing such economies. However, the usefulness of corporate groups is also limited in several ways. ${ }^{87}$

A major limitation on scale and scope economies in large firms is the agency problem described by Jensen and Meckling (1976). Aoki (1988, 1994) and others argue that Japanese corporate groups limit such problems. However, Morck, Stangeland, and Yeung (2000) and others show that the presence of a controlling shareholder in a pyramidal group is no delivery from agency problems; rather, it provides a different form of separation of ownership from control and new agency problems, such as entrenchment and tunneling.

Caves (1982) argues that important returns to scale involve innovation, and Goto (1982) finds that zaibatsu were big technology importers. ${ }^{88}$ Diversified groups of firms, importing technology and expanding rapidly in concert, might have allowed a "big push" growth strategy, as in Murphy, Shleifer, and Vishny (1989). However, a literature survey by Yafeh (2004) reports no similar finding for postwar keiretsu. Economies of scope in vertically integrated keiretsu are perhaps more plausible than in horizontal keiretsu, from, for example, just-in-time inventory management. This gave Japanese firms a worldwide reputation for efficiency in the 1980s. Huson and Nanda (1995) confirm that just-in-time inventory management adds value in U.S. firms if inventories are a large fraction of assets, but not otherwise. But little is actually known about the impact of just-in-time methods on the bottom line of the typical Japanese firm. Vertical keiretsu also shield corporate managers from takeovers, however. This became overtly evident in the failed 1989 hostile takeover by T. Boone Pickens of Koito Manufacturing, a first-tier supplier in the Toyota vertical keiretsu. Even after he became the largest single shareholder of Koito, Pickens could not put himself on Koito's board. This was because other members of the Toyota keiretsu collectively controlled more of Koito's shares than Pickens and acted in concert to block him. Keiretsu also appear vulnerable to tunneling, for the findings of Morck and Nakamura (1999) are certainly consistent with this. However, we are unaware of direct tests for tunneling in keiretsu.

Other economies of scale and scope can arise from superior managers

87. See Yafeh (2004) for a more detailed survey.

88. See, for example, Aoki (1988, chap. 6) and Blinder (1991) for a detailed presentation of this view regarding vertical keiretsu. See Morck, Shleifer, and Vishny (1990), Lang and Stulz (1994), and many others for evidence of agency problems associated with large, diversified firms. 
and workers. Morikawa (1980, pp. 16-19) reports that zaibatsu recruited top managers and technicians and argues this was a decided advantage. However, the collapse of the Suzuki zaibatsu was due to the concentration of corporate control in the hands of one exceptional manager-Naokichi Kaneko. Kaneko made few errors, but a single major mistake destroyed the entire zaibatsu.

The postwar keiretsu promised lifetime employment, so they were also preferred career paths for Japan's best university graduates. After the war, many older managers were tainted by wartime associations, engendering a renewed scarcity of talent at that time. ${ }^{89}$ Perhaps scarce superior management gave keiretsu an edge at critical points in Japanese history too. However, Morck and Nakamura (1999) find evidence of poor governance in keiretsu firms.

Yet another possible source of group economies of scale and scope is centralized capital allocation. ${ }^{90}$ Since external funds cost more than internal funds, a freestanding undiversified company is subject to the vagaries of cost and demand in a single industry. A group bank, or an apex firm that acts as a de facto bank, can move funds from member firms where they accumulate to where they are needed. Since the group bank has better information about the investment opportunities available to each firm, it can do this at much lower cost than could outside banks or financial markets. Miyajima (2000) finds little evidence of this in 1930s zaibatsu, but some in keiretsu. See also Weinstein and Yafeh (1998).

The depression-era failures of many zaibatsu cast further doubt on the merits of groups as capital allocators. The Mitsui, Mitsubishi, and Sumitomo banks, which avoided lending to their own group companies, survived the depressions. In contrast, zaibatsu, like Suzuki, that used their banks to allocate their capital to their own firms, failed. One possible reason is moral hazard-managers were more reckless if they had guaranteed financing from so-called organ banks. Another is diversification in management strategy - all the Suzuki firms followed the same strategy, whereas the Mitsui, Mitsubishi, and Sumitomo banks lent to firms with diverse strategies.

Hoshi, Kashyap, and Scharfstein (1990a,b, 1991, 1993) argue that such financial transfers reduce the cost of financial distress in keiretsu. ${ }^{91}$ Yafeh (2004) summarizes a literature showing depressed performance in keiretsu firms and less variation in their performance. This suggests a co-insurance,

89. Aoki $(1988,1994)$ proposes that keiretsu main banks were special repositories of managerial talent and lent their expertise to troubled keiretsu member firms. Corporate groups could allocate talent to where it was needed and so make efficient use of scarce governance expertise. Kaplan and Minton (1992), Morck and Nakamura (1999), and others show that bank executives were routinely transferred to the boards of financially troubled client firms later in the postwar period.

90. See Asashima (1982), Okazaki (1999), and others regarding zaibatsu, and Hoshi, Kashyap, and Scharfstein (1990a,b, 1991, 1993) and others regarding keiretsu.

91. But see Hayashi (2000). 
rather than banking, role-keiretsu banks rescue distressed member firms rather than funding the best firms. Morck and Nakamura (1999) argue that this perpetuated poor governance. Evidence in Hanazaki and Horiuchi $(2000,2001)$ and Bremer and Pettway (2002) suggests that it also promoted poor governance in the banks themselves and set the stage for Japan's 1990s financial crisis, which undermined the credibility of keiretsu main banks' commitments in any case.

Japanese corporate history tells against using a group bank as a financial clearinghouse or provider of financial insurance. Despite short-run advantages, it carries longer-term dangers. The Suzuki zaibatsu, and other groups with organ banks, prospered in the short run but failed when the economy as a whole took a downturn. The keiretsu main banks prospered during Japan's long postwar boom but are clearly having serious problems riding out the current prolonged downturn.

Thus, arguments for scale and scope economies in corporate groups must be balanced against a series of costs these structures impose.

\subsubsection{Institutional Asthenia}

If groups do not provide an advantage in general, they may do so under circumstances particular to Japan at critical points in its history. Corporate groups might then persist because of the path dependence of institutional development.

Khanna and Palepu (chap. 5 in this volume and elsewhere) argue that the economies of scale and scope from corporate groups are more likely to dominate these countervailing costs in economies with weaker institutions. Zaibatsu-like groups in modern India survive and prosper because they are an adaptation to market transactions made prohibitively costly by endemic fraud and corruption. Since group firms are all controlled by the same principal, they have greatly reduced incentives to cheat each other. This lets them do business more efficiently than freestanding firms, which depend on dysfunctional markets for capital, managers, labor, suppliers, and customers. Khanna and Palepu (2000) also argue that investments in reputation might have large returns to scale. The Tata family of India invested heavily in acquiring a reputation for fair dealing, sometimes at great financial cost. However, once it established a nationwide reputation for honesty in an otherwise highly corrupt economy, all manner of firms, banks, and individuals were willing to pay a premium to do business with Tata firms rather than risk being cheated. It seems plausible that similar conditions prevailed in Meiji and Taisho Japan.

This view is closely related to the idea that coordination across group companies reduces costs, as in Fruin (1992, p. 101) and others. Some popular accounts of keiretsu go further, arguing that group firms pool information from across a wide range of industries, unavailable to freestanding companies, to foresee critical events, react appropriately, and develop flex- 
ibility strategically. This seems implausible, for government planners seem chronically unable to reproduce this feat despite using the whole apparatus of the state to collect information for them.

However, such explanations take a weak institutional environment as given. This seems a strong assumption over the 135 years surveyed in this chapter. Haber (1989) argues that oligarchic families in Mexico, who controlled corporate pyramids much like zaibatsu, deliberately weakened institutions to benefit themselves and block the entry of competitors. The zaibatsu families are thought to have generally supported modernization programs and institutional development such as legal reforms. However, the zaibatsu families also clearly had close ties to the premilitary state and may have shaped institutions to benefit themselves. In postoccupation Japan, there is more discussion of keiretsu managers' lobbying for institutional weaknesses. It seems likely that keiretsu undermined the market for corporate control, thus short circuiting other corporate governance mechanisms, like proxy fights and institutional investor activism. The large banks and the keystone firms of the great horizontal keiretsu almost certainly lobbied for the suppression of the corporate bond market in postwar Japan. Thus, weak institutions may well have been a consequence, as well as a cause, of corporate groups.

\subsubsection{Private Benefits of Control}

This leads to another possibility - groups might benefit those who control them, rather than the economy as a whole. Zaibatsu families may have been willing to pay more for control blocks because they valued control per se more than other shareholders did. This might be because members of these families had utility functions that assigned greater weight to power. If the families were not the most able managers, this could have depressed publicly traded shares while raising the family's private valuation of its shares. Or private benefits of control might have existed because these families were more proficient than other shareholders at using control over corporate assets to enrich themselves. Likewise, the managers of postwar keiretsu firms organized those structures to stymie corporate takeover threats. If they garnered utility from their control of great corporations, these actions follow logically. ${ }^{92}$

92. It is theoretically possible that these managers were blocking takeovers out of beneficence. For example, their goal might have been to protect myopic shareholders from selling at a large premium to the raider because even larger run-ups in their share prices were likely in the future. However, the repeated empirical rejection of shareholder myopia models (e.g., Chan, Martin, and Kensinger 1990) undermines such arguments. Also, the top managers of many Japanese corporations receive fringe benefits including expensive housing, golf club membership, chauffeured automobile, and access to special restaurants. Even though their market value is quite high, none of these fringe benefits appear in the executives' income figures. As soon as they leave the executive positions, these benefits are usually taken away from the executives. 
There is considerable evidence for the existence of large private benefits of corporate control elsewhere. Johnson et al. (1985) show that stock prices rise significantly upon the deaths of the firms' aged CEOs. Morck, Shleifer, and Vishny (1988b) show that high managerial ownership in certain U.S. firms is associated with depressed public share prices. Barclay and Holderness (1989) show that control blocks trade at higher prices than small transactions. Dyck and Zingales (2004) show that this effect is greater in more corrupt countries. All of these studies are consistent with the existence of large private benefits of control. The finding of Dyck and Zingales in particular suggests that the size of private benefits is related to corruption, and it thus favors the view that these benefits involve the consumption of corporate wealth by the controlling shareholder.

The importance of maintaining control was evident in the house charters of the great zaibatsu families and in the autobiographical writings of Yoshisuke Aikawa (1934), the founder of the Nissan zaibatsu. Morck and Yeung (2003) argue that the extraction of private benefits of control is less dependent on talent than is genuine entrepreneurship, and that leaving one's heirs opportunities to extract such benefits is therefore a preferred way of providing for them.

A fixation on preserving control rights can lead to inefficiently riskaverse investment decisions. Thus, Miyajima (2000) reports that firms belonging to the three major zaibatsu exhibit greater risk aversion than firms belonging to newer zaibatsu. One explanation for this is more extensive private benefits of control for the principals of the established groups, though there are certainly others too.

In short, private benefits of control probably figured large in the formation of zaibatsu and keiretsu. This leaves open, however, the question of what other considerations might also have been important.

\subsubsection{Insulation from Market Pressures}

Another possibility is that corporate groups benefit the economy overall but that group firms nonetheless exhibit inferior performance in the eyes of investors. Much literature contemporaneous with the zaibatsu stresses their ability to ignore shareholders. For example, a Meiji-era report on the Kyushu Railway deplores how the company was "dominated from the start by the vulgar view that it had to economize on building outlays." This refers to a conflict described by Ushiba (1909) between "the stockholders desiring an increase in dividends even to the point of reducing the business, and the directors insisting on expanding the business even if it means cutting dividends." Ericson (1989) describes how a large shareholder, the banker Imamura Seinosuke, tried not only to curtail the railway's vast expansion plans but to force it to downsize in response to the economic downturn of 1890 .

Ericson (1989) applauds the railway's "substantial progress [sic] in sepa- 
rating management from ownership" and the professionalism of its president, Sengoku Mitsugu, who owned little stock and could therefore go "on pursuing his positive policies, thrusting aside a second attempt by disgruntled stockholders to interfere with his program in 1902." But Ericson concedes that such "sophistication" was the exception. The Kyushu and Sanyo railroads were Mitsubishi companies, and Mitsubishi "differed from most railway owners in its primary concern for indirect benefits of railway investment." That is, the Mitsubishi railroads were not intended to maximize shareholder value but to assist other Mitsubishi companies in transporting inputs and outputs.

The foregoing is a somewhat convoluted way of saying that the zaibatsu railways were forced to overexpand to reduce the shipping costs of other Mitsubishi companies, in a clear instance of "self-dealing" or "tunneling." However, this may not have been economically inefficient. Since railways have a public good component, it is possible that shareholder value maximization would lead to a suboptimal investment. Tunneling by the zaibatsu to overbuild might actually improve social welfare, though at the expense of the railways' other shareholders. By 1905, banks and insurance companies had emerged as the major shareholders in most railroads, and such selfsacrifice by railroad shareholders was at an end. The railroads were nationalized in 1906 and 1907, perhaps permitting more self-sacrifice by them.

Governments elsewhere took advantage of large corporate groups as preexisting command and control devices for implementing industrial policies. For example, Korea, Malaysia, and Sweden appear to have encouraged pyramidal groups so that government officials could influence the corporate sector by dealing directly with a few individuals - the patriarchs in charge of the pyramids. ${ }^{93}$ The governments in question seem to have believed, perhaps correctly, that these small group interactions allowed a highly effective transmission of government policies and a better coordination of private- and public-sector initiatives.

Certainly, the zaibatsu were more agile and willing than freestanding firms to change direction rapidly in order to accommodate changing government policy objectives. By rapidly expanding one firm with capital from others, the zaibatsu could quickly change direction and focus. Their large established capital bases also let them enter new industries quickly. Postwar keiretsu were also favored as vehicles through which industrial policy might be implemented (Komiya, Okuno, and Suzumura 1988; Okimoto 1989).

This agility was clearly beneficial in terms of endearing the zaibatsu and keiretsu to certain government officials. However, it did not always enrich the groups involved. The zaibatsu families lost out heavily after, and per-

93. See Högfeldt (chap. 9 in this volume) for details regarding Sweden. Morck and Yeung (2004) make the argument more generally. 
haps during, the war despite their groups' agility in expanding munitions production. More generally, deviating from value-maximizing behavior has dynamic costs that disadvantage the group over time, as in Morck and Nakamura (1999). This may explain the weakness of the keiretsu firms in present-day Japan.

\subsubsection{Economies of Scale and Scope in Political Rent Seeking}

A final possibility is that the close relationships corporate groups develop with government generated financial returns that compensated for profits lost while pursuing government objectives. Morck, Stangeland, and Yeung (2000), in discussing pyramidal groups throughout the world, argue that government officials and great mercantile family patriarchs, who come to know and trust each other, are likely to engage in mutual back scratching, favor trading, and other forms of corruption that, while beneficial for the family group of firms, can greatly damage the economy. Morck, Stangeland, and Yeung, Fisman (2001), Johnson and Mitton (2003), Rajan and Zingales (2003), and others present empirical evidence consistent with this more skeptical view.

There is considerable evidence that business-government relations in both prewar and postwar Japan were largely organized around rent seeking. Morikawa (1992, pp. 3-4) argues that political entrepreneurship, the use of ties to powerful political figures to obtain government favors, reaped huge returns in the provision of goods and services to the state and to stateowned enterprises in the Meiji period.

The great zaibatsu of prewar Japan all obtained a leg up on their competitors due to government favors. The Sumitomo obtained their cash-cow copper mines because of their close association with the Tokugawa regime. The Mitsui and Mitsubishi zaibatsu obtained cash-cow mining operations in questionably competitive privatizations by the Meiji government. All three prospered in prewar Japan in part because of their ability to give the government what it wanted when it wanted it. If the government decided Japan needed to export, the zaibatsu could move into export-oriented businesses. If the government decided Japan needed technology, the zaibatsu could rev up their machinery production. In short, the zaibatsu seemed able to react to the changing whims of government policymakers with greater nimbleness and forcefulness than other firms could manage.

In postwar Japan, the keiretsu firms and their main banks also appear to have been generously subsidized for their enthusiasm about industrial policy programs (Okimoto 1989). Indeed, Beason and Weinstein (1996) show that the greater part of Japan's postwar industrial subsidies went to mining firms, most of which were members of the large horizontal keiretsu. In contrast, independent companies like Honda were denied subsidies for deliberately contravening industrial policy plans by, for example, producing automobiles when told not to. 
The importance of rent seeking in postwar Japan is perhaps evident in the status accruing to employment in government. This status existed largely because of the attractions of a career path involving amakudariliterally, "descent from heaven." Amakudari involves an older, highranking government official leaving his post to become a senior manager in industry, and was a common path to the boardroom in postwar Japan. This practice may have made sense in the immediate postwar period, when there was perhaps a serious shortage of talent due to the purging of senior executives who had cooperated with the military government.

However, Van Rixtel (2002) and others argue that amakudari subsequently devolved into a system of regulatory capture, as in Stigler (1971). This was largely because of the genkyoku principle, whereby specific ministries claimed exclusive regulatory power over specific industries. Since civil servants in these ministries were prime candidates for amakudari, the ministries rapidly became vocal advocates within the government for the interests of their industries. For example, in the race for industrial promotion of biotechnology, the Ministry of Health wanted to participate in policymaking explicitly on behalf of the pharmaceutical industry, its traditional amakudari partner. Since the great keiretsu firms included the most attractive amakudari landing spots and were the most enthusiastic about amakudari, these groups may have enjoyed an advantage, in the short term at least, due to their better connections with government.

This regulatory capture is now thought by some researchers to have contributed to Japan's current economic and governance problems. ${ }^{94}$ Bureaucrats uncritically advanced industry agendas, hopeful of amakudari opportunities. Corporate executives, former bureaucrats, realized that their talents were in influencing government rather than overseeing new research and development programs. The result was an unhealthy regulatory morass that came to surround many established industries in Japan, and that is now the subject of much criticism.

\subsection{Conclusions}

During Japan's modern history, beginning in 1868 , its corporate sector was first organized into great family pyramids, or zaibatsu, then subjected to Soviet-style central planning, then reorganized into widely held firms, and finally restructured into keiretsu corporate groups. While many lessons lie in Japan's complicated development story, a few that have to do with the interaction between the corporate sector and Japan's institutions are especially noteworthy.

Although Japan specialists often write of zaibatsu as uniquely Japanese

94. See Horiuchi and Shimizu (2001) for a discussion of the role of amakudari in Japan's current economic downturn. 
constructs, they are typical of the family-controlled pyramidal groups that the other chapters in this volume show dominating the corporate sectors of most other countries. The postwar keiretsu, in contrast, are more uniquely Japanese. Zaibatsu were probably sensible structures for sidestepping Japan's early, and probably poorly functioning, markets. By doing business mainly with each other, zaibatsu firms could avoid being cheated or otherwise harmed in inefficient and opaque markets for goods, labor, and capital. The postwar keiretsu may have been, in part at least, a similar response to the chaotic early postwar years.

But both zaibatsu and keiretsu were also devices for entrenching insiders. Zaibatsu let great mercantile families and entrepreneurial individuals direct vast amounts of public investor capital yet retain full control of all the ventures so funded. Keiretsu probably formed to stop hostile takeovers and tenure professional managers. That insiders sought such entrenchment indicates that they received private benefits of control.

The passage of time exposed weaknesses of corporate groups.

One popular argument for groups is that group banks can finance group firms, avoiding information asymmetry problems and other capital market failures. Japanese history shows that such arrangements invite moral hazard and agency problems. Zaibatsu, like Suzuki, that followed this model, failed during the depression era. The current problems of the great horizontal keiretsu also seem to stem from a history of inefficient capital allocation.

Although zaibatsu and keiretsu might initially have been devices for extracting economies of scale from scarce talented managers, by entrenching insiders they ultimately kept talented outsiders out of boardrooms. This certainly affected firm-level performance. But it may have retarded macroeconomic growth as well. Morikawa $(1980,1992)$ argues that entrenched zaibatsu families' risk aversion and aversion to external financing to preserve family control retarded prewar Japan's growth. He argues that few projects for Japan's industrialization were initiated by zaibatsu. Morck, Nakamura, and Shivdasani (2000) argue that oversight by entrenched bankers may have had a similar effect on keiretsu firms.

Yet despite these and other weaknesses, corporate groups persisted.

In part this may have been because they retained genuine economies of scale and scope. Zaibatsu in particular funneled foreign technology into Japan, probably continually renewing their economies of scale.

But both zaibatsu and keiretsu probably also altered Japanese institutions to favor their continued importance. Both supported Japan's political elite vigorously at critical historical junctures. By participating enthusiastically in government industrial policies, no matter how wrongheaded, zaibatsu and keiretsu nurtured relationships that generated both subsidies and political influence. This influence was often instrumental in securing lasting advantages over the competition, as when the early zaibatsu fami- 
lies obtained tax-farming concessions, mines, and government contracts. The cooperation of zaibatsu and keiretsu with industrial policies probably led to captive regulator problems. Entire ministries were likely captured by industrial groups through genkyoku and amakudari. This undermined the state's ability to regulate prudently the economy and the financial system, and locked in favoritism to established large firms that "played the game." The collapse of the Suzuki zaibatsu because of its lack of political connections is the exception to prove this rule. In the postwar period, keiretsu banks and firms also benefited disproportionately from regulatory favoritism and overt subsidies. By lobbying for the suppression of the corporate bond market in postwar Japan, main keiretsu banks seriously weakened the financial system overall.

Thus, zaibatsu and keiretsu survived the institutional conditions that gave them birth. By investing heavily in political connections, they prolonged their competitive advantage even as the institutional deficiencies underlying their formation faded. But this political rent seeking prolonged some institutional weaknesses and engendered others.

Murphy, Shleifer, and Vishny (1991) and many others show pervasive rent seeking to impede growth. This is because it diverts talented individuals from genuine entrepreneurship toward more lucrative careers in rent seeking. Both rent seeking and innovation have increasing returns to scale for individuals and firms. However, rent seeking is a zero or negative-sum game, while innovation is a positive-sum game. Diverting talent into ever more lucrative rent seeking diverts ever greater resources into zero or negative-sum games, and thus slows growth.

We do not argue that groups are wholly bad. Rather, Japan's history exposes how groups in general, and groups that rely on internal capital markets in particular, can distort institutional development.

\section{References}

Acemoglu, Daron, Simon Johnson, and James Robinson. 2001. The colonial origins of comparative development: An empirical investigation. American Economic Review 91 (5): 1369-1422.

Aikawa, Yoshisuke. 1934. New capitalism and holding companies. Tokyo: Tokyo Bankers Association.

Allen, Franklin, and Douglas Gale. 2000. Comparing financial systems. Cambridge: MIT Press.

Aoki, Masahiko. 1988. Information, incentives, and bargaining in the Japanese economy. Cambridge, MA: Cambridge University Press.

1994. Monitoring characteristics of the main bank system: An analytical and developmental view. In The Japanese main bank system: Its relevancy for developing and transforming economies, ed. Masahiko Aoki and Hugh Patrick, 10941. Oxford and New York: Oxford University Press. 
Aoki, Masahiko, and Paul Sheard. 1992. The role of the main bank in the corporate governance structure in Japan. Paper presented at conference Corporate Governance: New Problems and New Solutions Structure in Japan. 1-2 May, Stanford, California.

Asajima, Shoichi. 1984. Financing of the Japanese zaibatsu. In Family business in the era of industrial growth, ed. Akio Okochi and Shigeaki Yasuoka, 95-117. Tokyo: University of Tokyo Press.

Asashima, Shoichi. 1982. Senkanki Sumitomo zaibarsu keieishi [Inter-war period Sumitomo zaibatsu business history]. Tokyo: University of Tokyo Press.

Barclay, Michael, and Clifford Holderness. 1989. Private benefits from control of corporations. Journal of Financial Economics 25:371-95.

Beale, Adolf, and Gardiner Means. 1932. The modern corporation and private property. New York: Macmillan.

Beason, Richard, and David E. Weinstein. 1996. Growth, economies of scale, and targeting in Japan (1955-1990). Review of Economics and Statistics (78) 2:28695.

Bertrand, M. P., P. Mehra, and S. Mullainathan. 2002. Ferreting out tunneling: An application to Indian business groups. Quarterly Journal of Economics 117:12148.

Bisson, T. 1954. Zaibatsu dissolution in Japan. Berkeley: University of California Press.

Blinder, Alan S. 1991. A Japanese buddy system that could benefit U.S. business. Business Week, October 14, 32.

Boot, Arnoud, and Anjan Thakor. 2000. Can relationship banking survive competitions? Journal of Finance 55:679-713.

Bremer, Marc, and Richard Pettway. 2002. Information and the market's perceptions of Japanese bank crisis: Regulation, environment, and disclosure. Pacific Basin Finance Journal 10:119-39.

Caves, Richard. 1982. Multinational enterprise and economic analysis. Cambridge: Cambridge University Press.

Caves, Richard, and Masu Uekusa. 1976. Industrial organization in Japan. Washington, DC: Brookings Institution.

Cha, Myung Soo. 2001. The origins of the Japanese banking panic of 1927. Institute of Economic Research Discussion Paper Series A no. 408. Tokyo: Hitotsubashi University.

Chan, Su, John Martin, and John Kensinger. 1990. Corporate research and development expenditures and share values. Journal of Financial Economics 26:25566.

Claessens, Stijn, Simeon Djankov, Joseph Fan, and Larry Lang. 2002. Disentangling the incentive and entrenchment effects of large shareholdings. Journal of Finance 57 (6): 2741-71.

Claessens, Stijn, Simeon Djankov, Larry H. P. Lang. 2000. The separation of ownership and control in East Asian corporations. Journal of Financial Economics 58 (1-2): 81-112.

Dower, John. 2000. Embracing defeat: Japan in the aftermath of World War II. East Rutherford, NJ: Penguin Books.

Dyck, Alexander, and Luigi Zingales. 2004. Private benefits of control: An international comparison. Journal of Finance 59 (2): 537-601.

Ericson, Steven. 1989. Private railroads in the Meiji Era: Forerunners of modern Japanese management. In Japanese management in historical perspective, ed. Tsunehiko Yui and Keiichiro Nakagawa, 51-77. Tokyo: University of Tokyo Press. 
Faccio, Mara, and Larry H. P. Lang. 2003. The separation of ownership and control: An analysis of ultimate ownership in Western European countries. Journal of Financial Economics 65 (3): 365-95.

Fisman, Raymond. 2001. Estimating the value of political connections. American Economic Review 91 (4): 1095-1103.

Fletcher, William Miles III. 1989. The Japanese business community and national trade policy 1920-1942. Chapel Hill: University of North Carolina Press.

Fouraker, L. 2002. Precursors of convergence in interwar Japan: Kaneko Naokichi and the Suzuki Trading Company. Paper presented at Media in Transition 2: Globalization and Convergence. 10-12 May, Cambridge, Massachusetts.

Fraser, Donald, S. Ghon Rhee, and Guen Hwan Shin. 2002. The impact of interbank and capital market competition on relationship banking: Evidence from the Japanese experience. University of Hawaii, College of Business Administration. Working Paper.

Fruin, W. Mark. 1983. Kikkoman: Company, clan, and community. Cambridge, MA: Harvard University Press.

— 1992. The Japanese enterprise system: Competitive strategies and cooperative structures. New York: Oxford University Press.

Fukuzawa, M. 1930. Zaikai jinbutsu gakan [Business leaders: Personal views]. Tokyo: Daiamondsha.

Gerlach, Michael L. 1992. Alliance capitalism: The social organization of Japanese business. Berkeley: University of California Press.

Glaeser, Edward, and Andrei Shleifer. 2002. Legal Origins. Quarterly Journal of Economics 117 (4): 1193.

Gompers, Paul, and Josh Lerner. 2002. The venture capital cycle. Cambridge: MIT Press.

Goto, Akira. 1982. Business groups in a market economy. European Economic Review 19:53-70.

Haber, Stephen. 1989. Industry and underdevelopment: The industrialization of Mexico, 1890-1940. Stanford, CA: Stanford University Press.

Hadley, Eleanor. 1970. Antitrust in Japan. Princeton, NJ: Princeton University Press.

Hamada, Koichi. 1998. The incentive structure of a managed market economy: Can it survive the millennium? American Economic Review 88 (2): 417-21.

Hanazaki, Masuharu, and Akiyoshi Horiuchi. 2000. Is Japan's financial system efficient? Oxford Review of Economic Policy 16 (2): 61-73.

- 2001. A vacuum of governance in the Japanese bank management. In Banking, capital markets and Corporate Governance, ed. H. Osano and T. Tachibanaki, 133-80. London and New York: Palgrave.

. 2003. A review of Japan's bank crisis from the governance perspective. Hitotsubashi University, Institute of Economic Research. Working Paper.

2004. Can the financial restraint theory explain the postwar experience of Japan's financial system? In Designing financial systems in East Asia and Japan, ed. Joseph P. H. Fan, Masuharu Hanezaki, and Juro Teranishi, 19-46. London: Routledge-Curzon.

Hasegawa, Yasubei. 1938. Kabushiki Kaisha no Shomondai [Various issues of joint stock companies]. Tokyo: Tokyo Taibunsha.

Hashimoto, J. 1997. Japanese industrial enterprises and the financial market between the two World Wars. In Finance in the age of the corporate economy: The third Anglo-Japanese business history conference, ed. P. L. Cottrell, A. Teichova, and T. Yuzawa, 94-117. Hants, UK: Ashgate.

Hayashi, Fumio. 2000. The main bank system and corporate investment: An empirical assessment. In Finance, governance, and competitiveness in Japan, ed. 
Masahiko Aoki and Gary Saxonhouse, 81-97. Oxford and New York: Oxford University Press.

He, Kathy, Randall Morck, and Bernard Yeung. 2004. Stability. University of Alberta, School of Business. Working Paper.

Hellman, Thomas, Kevin Murdock, and Joseph Stiglitz. 2000. Liberalization, moral hazard in banking, and prudent regulation: Are capital requirements enough? American Economic Review 90 (1): 147-65.

Hirschmeier, Johannes. 1964. The origins of entrepreneurship in Japan. Cambridge, MA: Harvard University Press.

Hirschmeier, Johannes, and Tsunehiko Yui. 1981. The development of Japanese business. 2nd ed. London: Allen and Unwin.

Holding Companies Liquidation Commission (HCLC). 1950. Nihon zaibatsu to sono katai [Japanese zaibatsu and its dissolution]. Tokyo: Shinyohen.

Horiuchi, Akiyoshi. 1999. Nihonni okeru kinyu kozo no kiso: Tenbo [The basis of Japan's financial structure: A survey]. Japanese Ministry of Finance Research Institute Financial Review (June): 1-32.

Horiuchi, Akiyoshi, and Katsutoshi Shimizu. 2001. Did Amakudari undermine the effectiveness of regulator monitoring in Japan? Journal of Banking and Finance 25 (3): 573-96.

Hoshi, Takeo. 1995. Cleaning up the balance sheets: Japanese experience in the post-war reconstruction period. In Corporate governance in transitional economies: Insider control and the role of banks, ed. M. Aoki and H.-K. Kim, 303-59. Washington, DC: World Bank.

Hoshi, Takeo, and Anil Kashyap. 2001. Corporate financing and governance in Japan: The road to the future. Cambridge: MIT Press.

Hoshi, Takeo, Anil Kashyap, and David Scharfstein. 1990a. Bank monitoring and investment: Evidence from the changing structure of Japanese corporate banking relationship. In Asymmetric information, corporate finance, and investment, ed. Glenn Hubbard, 67-88. Chicago: University of Chicago Press.

1990b. The role of banks in reducing the costs of financial distress in Japan. Journal of Financial Economics 27:67-88.

- 1991. Corporate structure, liquidity, and investment: Evidence from Japanese industrial groups. Quarterly Journal of Economics 106:33-60.

Hoshi, Takeo, Anil Kashyap, and David Scharfstein. 1993. The choice between public and private debt: An analysis of post-deregulation corporate financing in Japan. Massachusetts Institute of Technology, Sloan School of Management. Unpublished manuscript.

Hoskins, Geoffrey. 1992. The first socialist state: A history of the Soviet Union from within. 2nd ed. Cambridge, MA: Harvard University Press.

Huson, Mark, and Dhananjay Nanda. 1995. The impact of just-in-time manufacturing on firm performance in the US. Journal of Operations Management 12 (34): $297-311$.

Ito, Masanao. 2001. Showashonen no kinyu system kiki: Sono kozo to taio [The financial system crisis in the 1920s: The structure and responses]. Institute of Monetary and Economic Studies Paper no. 2001-J-24. Tokyo: Bank of Japan.

Jensen, Michael, and William Meckling. 1976. The theory of the firm: Managerial behavior, agency costs and ownership structure. Journal of Financial Economics 3:305-60.

Johnson, Simon, Rafael La Porta, Florencio López-de-Silanes, and Andrei Shleifer. 2000. Tunneling. American Economic Review 90 (2): 22-27.

Johnson, Simon, and Todd Mitton. 2003. Cronyism and capital controls: Evidence from Malaysia. Journal of Financial Economics 67 (2): 351-82.

Johnson, W. Bruce, Robert P. Magee, Nandu J. Nagarajan, and Henry A. Newman. 
1985. An analysis of the stock price reaction to sudden executive deaths: Implications for the management labor model. Journal of Accounting and Economics 7 (1-3): 151-74.

Kaneko, Naokichi. 1928. Suzuki okoku [The Suzuki Kingdom]. Osaka Asahi Shimbun, 19-21 April.

Kaplan, Steven, and Bernadette Minton. 1992. Outside intervention in Japanese companies: Its determinants and its implications for managers. Journal of Financial Economics 36:225-58.

Kato, T. 1957. Honpo ginkoshiron [History of banks in Japan]. Tokyo: University of Tokyo Press.

Katsura, Yoshio. 1976. Failure in zaibatsu making: Suzuki Shoten. In Nihonno zaibatsu [Japanese zaibatsu], ed. Shigeaki Yasuoka, 177-223. Tokyo: Nikkie.

Khanna, Tarun, and Krishna Palepu. 2000. Is group affiliation profitable in emerging markets? An analysis of diversified Indian business groups. Journal of Finance 55 (2): 867-93.

Kobayashi, Masaski. 1985. Japan's early industrialization and the transfer of government enterprises: Government and business. Japanese Yearbook on Business History: 1985 2:54-80.

Kojima, Kenji. 1997. Japanese corporate governance. Kobe University, Research Institute for Economics and Business Administration. Working Paper.

Komiya, Ryutaro, Masahiro Okuno, and Kotaro Suzumura, eds. 1988. Industrial policy of Japan. New York: Academic Press.

La Porta, Rafael, Florencio López-de-Silanes, Andrei Shleifer, and Robert Vishny. 1999. Corporate ownership around the world. Journal of Finance 54 (2): 471-520.

Lang, Larry, and René Stulz. 1994. Tobin's $q$, corporate diversification, and firm performance. Journal of Political Economy 102:1248-80.

Lincoln, J., M. Gerlach, and C. Ahmadjian. 1996. Keiretsu networks and corporate performance in Japan. American Sociological Review 61:67-88.

Lincoln, J., M. Gerlach, and P. Takahashi. 1992. Keiretsu networks in the Japanese economy: A dyad analysis of intercorporate ties. American Sociological Review 57:561-85.

McMillan, Charles. 1984. The Japanese industrial system. Berlin: De Gruyter.

Ministry of Finance. 1983. Hojin kigyo tokei [Incorporate businesses statistics]. Tokyo: Ministry of Finance.

Mishima, Y., ed. 1981. The Mitsubishi zaibatsu [in Japanese]. Tokyo: Nikkei.

Mitsubishi Bank. 1954. Mitsubishi ginkoshi [History of the Mitsubishi bank]. Tokyo: Mitsubishi Bank.

Miwa, Yoshiro, and J. Mark Ramseyer. 2002. The fable of the keiretsu. Journal of Economics and Management Strategy 11:169-224.

Miyajima, Hideaki. 1994. Transformation of zaibatsu to postwar corporate groups: From hierarchically integrated groups to horizontally integrated groups. Journal of the Japanese and International Economies 8:293-328.

1999. Presidential turnover and performance in the Japanese firm: The evolution and change of the contingent governance structure under the main bank system. In Japanese management in the low growth era: Between external shocks and internal evolution, ed. Daniel Dirks, Jean-Francois Huchet, and Thierry Ribault, 121-44. Heidelberg: Springer.

. 2000. Nihon kigyono shoyukozo, shihon kosei, setsubitoshi: Senkanki to kodo seichokino kozo hikaku [Ownership structure, capital structure and investment of Japanese corporations: Comparison between the inter-war period and high-growth period]. Waseda University (Tokyo), Faculty of Commerce. Mimeograph. 
Miyamoto, Matao. 1984. The position and role of family business in the development of the Japanese company system. In Family business in the era of industrial growth, ed. Akio Okochi and Shigeaki Yasuoka, 39-91. Tokyo: University of Tokyo Press.

Morck, Randall. 2005. How to eliminate pyramidal business groups: The double taxation of inter-corporate dividends and other incisive uses of tax policy. In Tax policy and the economy, ed. James Poterba. Cambridge: MIT Press, forthcoming.

Morck, Randall, and Masao Nakamura. 1999. Banks and corporate control in Japan. Journal of Finance 54:319-39.

2001. Japanese corporate governance and macroeconomic problems. In The Japanese business and economic system: History and prospects for the 21st century, ed. Masao Nakamura, 325-49. New York: Palgrave Macmillan.

Morck, Randall, Masao Nakamura, and Anil Shivdasani. 2000. Banks, ownership structure, and firm value in Japan. Journal of Business 73:539-69.

Morck, Randall, Andrei Shleifer, and Robert Vishny. 1988a. Characteristics of targets of hostile and friendly takeovers. In Corporate takeovers: Causes and consequences, ed. Allan Auerbach, 101-29. Chicago: University of Chicago Press.

- 1988b. Management ownership and market valuation: An empirical analysis. Journal of Financial Economics 20 (1-2): 293-315.

. 1989. Alternative mechanisms for corporate control. American Economic Review 79 (4): 842-52.

. 1990. Do managerial objectives drive bad acquisitions? Journal of Finance 45 (1): 31-48.

Morck, Randall, David A. Stangeland, and Bernard Yeung. 2000. Inherited wealth, corporate control, and economic growth: The Canadian disease. In Concentrated corporate ownership, ed. Randall Morck, 319-69. Chicago: University of Chicago Press.

Morck, Randall, and Bernard Yeung. 2003. Agency problems in large family business groups. Entrepreneurship Theory and Practice 27 (4): 367-82.

. 2004. Family firms and the rent seeking society. Entrepreneurship Theory and Practice 28 (4): 391-409.

Morikawa, Hidemasa. 1976. Chiho zaibatsu [Local zaibatsu]. In Nihonno zaibatsu [Japanese zaibatsu], ed. S. Yasuoka, 146-75. Tokyo: Nikkei.

- 1980. Zaibatsuno keieishiteki kenkyu [Business history research of zaibatsu]. Tokyo: Toyo Keizai.

. 1992. Zaibatsu: The rise and fall of family enterprise groups in Japan. Tokyo: University of Tokyo Press.

Murphy, Kevin, Andrei Shleifer, and Robert Vishny. 1989. Industrialization and the big push. Journal of Political Economy 97:1003-26.

. 1991. The allocation of talent: Implications for growth. Quarterly Journal of Economics 106 (2): 503-30.

Nakamura, Takafusa, and Konosuke Odaka, eds. 2003. The economic history of Japan: 1914-1955-a dual structure. Oxford, UK: Oxford University Press.

Nissho. 1968. Nissho 40nen no Ayumi [History of Nissho's 40 years]. Tokyo: Nissho.

Noguchi, Yukio. 1998. The 1940 system: Japan under the wartime economy. American Economic Review Papers and Proceedings 88 (May): 404-6.

Ogura, S. 2002. Banking, the state and industrial promotion in developing Japan, 1900-73. Houndmills, UK: Palgrave.

Okazaki, Tetsuji. 1994. The Japanese firm under the wartime planned economy. In The Japanese firm: Sources of competitive strength, ed. Masashiko Aoki and Ronald Dore, 350-75. Oxford University Press. . 1999. Mochikabu kaishano keizaishi: Zaibatsuto kigyo tochi [Economic his- 
tory of the holding company: Zaibatau and corporate governance]. Tokyo: Chikuma Shobo.

Okazaki, Tetsuji, and Masahiro Okuno-Fujiwara. 1993. Gendai Nihon Keizai Sisutemu no Genryu [The origin of the contemporary Japanese economic system]. Tokyo: Toyo Keizai.

Okazaki, Tetsuji, and Kazuki Yokoyama. 2001. Governance and performance of banks in prewar Japan: Testing the "organ bank" hypothesis quantitatively. Center for International Research on the Japanese Economy Discussion Paper no. CJRJE-F-111. University of Tokyo, April.

Okimoto, Daniel. 1989. Between MITI and the market. Stanford, CA: Stanford University Press.

Okumura, H. 1976. Nihonno rokudai kigyo shudan [Six major Japanese corporate groups]. Tokyo: Diamondsha.

Patrick, Hugh. 1967. Japan. In Banking in the early stages of industrialization, ed. Rondo Cameron, Olga Crisp, Hugh T. Patrick, and Richard Tilly, 239-89. Oxford University Press.

Porter, Michael. 1990. The competitive advantage of nations. New York: Free Press.

Rajan, Raghuram. 1992. Insiders and outsiders: The choice between relationship and arm's length debt. Journal of Finance 47:1367-1400.

Rajan, Raghuram, and Luigi Zingales. 2003. The great reversals: The politics of financial development in the twentieth century. Journal of Financial Economics 69 (1): 5 .

Reischauer, Edwin O. 1988. The Japanese today: Change and continuity. Cambridge, MA: Harvard University Press.

Sataka, Makoto. 1994. Sengo kigyo jikenshi [Postwar corporate events]. Tokyo: Kodansha.

Sheard, Paul. 1991. The economics of interlocking shareholding in Japan. Richerche Economiche 45:421-48.

-1994. Interlocking shareholdings and corporate governance. In The Japanese firm: Sources of competitive strength, ed. Masahiko Aoki and Ronald Dore, 310-49. Oxford University Press.

Shiomi, Saburo. 1957. Japan's finance and taxation: 1940-1956. New York: Columbia University Press.

Shogyo Koshinsho. 1930. Mitsui zaibatsu. Tokyo: Shogyo Koshinsho.

Stigler, George. 1971. The theory of economic regulation. Bell Journal of Economics and Management Science 2 (Spring): 3-21.

Takahashi, Kamekichi. 1930a. Kabushiki Gaisha Bokokuron [The stock company: A cause of national decay]. Tokyo: Banrikaku Shobo.

- 1930b. Nihon zaibatsu no kaibo [Analysis of Japanese zaibatsu]. Tokyo: Chuokoronsha.

Takahashi, Kamekichi, and J. Aoyama. 1938. Nihon zaibatsu ron [The Japanese zaibatsu]. Tokyo: Shunjusha.

Takeda, Haruhito. 1995. Daikigyo no kozo to zaibatsu [The structures of large firms and zaibatsu]. In Daikigyo jidai no torai [Arrival of large corporations], ed. T. Yui and E. Daito, 79-115. Tokyo: Iwanami.

Tamaki, Hajime. 1976. Nihon zaibatsushi [History of Japanese zaibatsu]. Tokyo: Shakai Shisosha.

Tamaki, Norio. 1995. Japanese banking: A history, 1859-1959. Cambridge: Cambridge University Press.

Teranishi, Juro. 1999. The main bank system. In The Japanese economic system and its historical origins, ed. Tetsuji Okazaki and Masahiro Okuno-Fujiwara, 63-96. Oxford University Press. 
2000. The fall of the Taisho economic system. In Finance governance and competitiveness in Japan, ed. Masahiko Aoki and Gary Saxonhouse, 43-63. Oxford University Press.

2003. Nihon no keizai system. Tokyo: Iwanami.

Toyo Keizai. 1991. Kigyo Keiretsu Soran '92 [Company keiretsu groupings 1992]. Tokyo: Toyo Keizai Shimposha.

Udagawa, M. 1976. Shinko zaibatsu [New zaibatsu]. In Nihonno zaibatsu [Japanese zaibatsu], ed. S. Yasuoka, 107-44. Tokyo: Nikkei.

Ushiba, Takuzo. 1909. Tetsudo eigyo no hoshin [Policies in railway management]. In 10 nen Kinen no Tetsudo [The 10-year-old Japanese railway], ed. R. Kinoshita, 274-86. Tokyo: Jiho Kyoku. Previously published in Tetsudo jiho 14 (1899).

Weinstein, David, and Yishay Yafeh. 1998. On the costs of a bank centered financial system: Evidence from the changing main bank relations in Japan. Journal of Finance 9:154-73.

Yafeh, Yishay. 1995. Corporate ownership, profitability, and bank-firm ties: Evidence from the American occupation reforms in Japan. Journal of the Japanese and International Economies 9:154-73.

2000. Corporate governance in Japan: Past performance and future prospects. Oxford Review of Economic Policy 16 (2): 74-84.

- 2004. Japan's corporate groups: Some international and historical perspectives. In Structural impediments to growth in Japan, ed. M. Blomstrom, J. Corbett, F. Hayashi, and A. Kashyap. Chicago: University of Chicago Press.

Yamamura, Kozo. 1976. General trading companies in Japan: Their origins and growth. In Japanese industrialization and its social consequences, ed. Hugh Patrick, 161-99. Berkeley: University of California Press.

Yamazaki, H. 1988. The development of large enterprises in Japan: An analysis of the top 50 enterprises in the profit ranking table (1929-1984). Japanese Yearbook on Business History 5:12-55.

Yasuoka, Shigeaki, ed. 1976. Nihonno zaibatsu [Japanese zaibatsu]. Tokyo: Nikkei. 1984. Capital ownership in family companies: Japanese firms compared with those in other countries. In Family business in the era of industrial growth, ed. Akio Okochi and Shigeaki Yasuoka, 1-32. Tokyo: University of Tokyo Press.

\section{Comment Sheldon Garon}

In their chapter, Randall Morck and Masao Nakamura write that "Japan's corporate sector has, over the past century, been reorganized according to every major corporate governance model.' Nearly the same could be said for the shifting interpretations of corporate governance in Japan - particularly those of the combines known as zaibatsu before 1945 and the business groups called keiretsu following World War II. Prewar Marxists criticized the zaibatsu for their concentration of wealth, while rightists attacked (sometimes literally) zaibatsu leaders for their profit-making, unpatriotic behavior. To the Americans who occupied a defeated Japan between 1945 
and 1952, the zaibatsu constituted the most formidable obstacle to building economic democracy in the New Japan. Arguing that the zaibatsu had abetted wartime militarism and stunted the growth of a healthy smallbusiness sector, the occupation broke the big four zaibatsu into scores of independent firms. Or so the Americans thought. The old zaibatsu units and other firms soon regrouped into the more loosely constituted keiretsu. As Japan achieved its "economic miracle" in the 1950s and 1960s and increasingly challenged U.S. business interests, historical evaluations of the zaibatsu and keiretsu shifted again, from criticism to admiration. Chalmers Johnson (1982) judged that the zaibatsu had contributed to prewar economic development with their economies of scale, their pioneering role in commercializing modern technologies, their close cooperation with the state's developmental agenda, and above all their "introduction of a needed measure of competition into the [state's] plan-rational system" (p. 23). Johnson similarly lauded the bank-centered keiretsu for their contribution to postwar economic growth (pp. 204-6). When the Japanese economy sunk into its long decade of slow growth and no-growth after 1991, observers generally concluded that Japan's corporate governance- - so recently praised - had for a long time in fact impeded economic growth. Or as Morck and Nakamura state here, the zaibatsu and especially the keiretsu enthusiastically engaged in rent seeking that "probably retarded financial development and created long-term economic problems."

Their chapter offers a sweeping historical analysis of the changes in corporate ownership of the zaibatsu and keiretsu, beginning with era of the Tokugawa shoguns (1603-1868). For students of Japanese economic history, the most valuable contribution may be the detailed structural analysis of ownership and governance within a variety of the major combines both before and after 1945. The authors also challenge the thesis of "transwar" continuity, or in Yukio Noguchi's formulation, the "1940 system." Johnson, Noguchi, and others describe how Japanese enterprises, which before the 1930s depended significantly on equity markets, became heavily reliant on banking capital during World War II, and they suggest that this pattern of bank-centered finance continued unabated into the postwar era (Noguchi 1995, pp. 8-9). Morck and Nakamura instead reveal the reappearance of a vibrant equity market following the occupation's dissolution of the big zaibatsu in the late 1940s. The ensuing wave of corporate raids and attempts at hostile takeovers, the authors cogently argue, prompted the former zaibatsu firms to defend themselves by restoring some of their ties in the form of keiretsu and by instituting cross-shareholding against the raiders.

By adopting a long-range historical perspective, the authors provide a set of persuasive explanations for the rise and persistence of the prewar zaibatsu and the postwar keiretsu. These explanations cluster around (a) the combines' advantages in environments of weak markets, low trust, and 
scarce managerial talent, (b) the ongoing quest for control of the firms and pyramids by the family owners and sometimes their trusted managers, and (c) the combines' symbiotic relations with the state.

The paper, moreover, offers useful ways of defining and understanding the zaibatsu. Amid the confusion over what constituted a zaibatsu, the U.S. occupation ended up restricting the category - and thus its dissolution policy - to only the big four combines: Mitsui, Mitsubishi, Sumitomo, and Yasuda. However, there is much utility in the authors' inclusive definition of a zaibatsu as any "large pyramidal group of publicly traded firms." By opting for a more expansive definition, the paper ably revisits the question of whether there were substantial differences between the so-called old and new zaibatsu in the 1920s and 1930s. The authors demonstrate that these distinctions may have been more apparent than real, as the old zaibatsu moved into military-related chemical and heavy industry-much as the new zaibatsu were doing - and these operations constituted rapidly growing shares of each concern's profits. Furthermore, the old zaibatsu resembled the new zaibatsu in financing their heavy/chemical industrial firms by relying on equity.

The chapter's contributions notwithstanding, the argument could have been strengthened in several areas. I begin with questions about the overall analysis. The title is baffling because it obscures the agency of the actors in this story. Are we to assume that leaders of Japanese corporations, like the proverbial frog in the title, only viewed their reflection at the bottom of the well and remained ignorant of the world? Or, in the authors' words, have "the Japanese literally searched the world for the best institutions of capitalism, and changed their institutions more radically . . . than in any other major industrial economy"? And if so, who, precisely, played the key roles in changing these institutions - the U.S. occupation, the Japanese state, or the zaibatsulkeiretsu? Second, the chapter is subtitled "A History of Corporate Ownership in Japan," yet the paper presents little evidence of alternative models of ownership outside the zaibatsu and keiretsu. One wonders about ownership patterns within the small- and medium-business sector, which employed many more people and was central to the prewar export sector (more so than the zaibatsu). By the 1920s and 1930s, small businesses had organized themselves effectively as a political bloc and were influencing government policy. In the 1950s, curiously, the man who unified the small-business associations was none other than Aikawa Yoshisuke (also written Ayukawa Gisuke), pioneer of the prewar Nissan zaibatsu (Garon and Mochizuki 1993, pp. 145-66; Samuels 2003, p. 236). Although this chapter focuses on the zaibatsulkeiretsu, we must note that the big combines coexisted in uneasy political and economic relationships with smaller firms.

Because the paper covers the century-and-a-half evolution of the zaibatsu and keiretsu, it is also appropriate to raise several historically based 
questions about the analysis. The authors have not read widely in the general historiography of modern Japan, and several of their historical judgments rest on decades-old interpretations or the anachronistic assumptions of present-day economists. One of the more egregious anachronisms appears in their statement that the Tokugawa shogunate's "antiglobalization backlash continued to hermetically isolate Japan" between the 1630s and the 1850s. Globalization is hardly the apt term to describe the world of European monopolistic trading companies, nor did the shoguns "hermetically" isolate Japan, which continued to trade with the Dutch, Koreans, and Chinese.

The chapter's most serious historiographical problems lie in the analysis of the wartime economic order (1931-45) and its legacies for postwar corporate governance. The authors insist that wartime Japan was a "rigidly centrally planned economy," in which the state "de facto nationalized all its major corporations, subordinating them to central planners." By 1945, they conclude, "Japan had an economy little different from that of Russia in the 1920s," and the nation, "though a former right-wing dictatorship, was nonetheless virtually as centrally planned as many Eastern European countries were in 1989." By 1938, claim Morck and Nakamura, "most senior economic planners under the military government were Soviet trained." As further evidence, they cite the wartime compulsory cartels known as "control associations" (tôseikai), arguing that the cartels' "control committees, of course, would end up staffed by military personnel." Referring to the weakening influence of the zaibatsu families due to the wartime regime's controlled economy, the authors describe the drama as one of "marching into serfdom"- - the comfortable scions apparently playing the role of the serfs.

These are extraordinary statements. Rarely are they totally wrong, but in all cases they suffer from exaggeration or inadequate evidence. Let us begin with how the zaibatsu fared under wartime controls. By nearly all accounts, the zaibatsu not only prospered during World War II but increased their domination over the economy. Despite some attempts by the army to diminish their influence in the early 1930s, the zaibatsu - both "new" and "old" - benefited tremendously from the exploitation of the militarily occupied territories of Manchuria, China, and Southeast Asia. Although the zaibatsu often protested state intervention in the economy, in practice they took advantage of wartime controls to strengthen themselves against rivals. The U.S. occupation's foremost authorities on the subject emphatically concluded that the industrywide control associations had permitted the zaibatsu to reserve for themselves the lion's share of resources and finance, thereby weakening and even destroying smaller firms within each cartel. The control associations, noted T. A. Bisson (1954), were "manned almost exclusively by top Zaibatsu personnel" — not military men — and "in essence they merely added government sanction to the kind of behav- 
ior practiced by the combines when on their own" (p. 13). The big employers also used the bureaucratically imposed labor-management councils in each workplace to decimate the remnants of organized labor (Garon 1987, chap. 6).

In addition, the authors remain unclear about the fate of dividends. They assert that "dividends were restricted so that earnings could be reinvested patriotically." At other points, they suggest that dividends for zaibatsu families were "apparently now sharply curtailed," and the most recent draft claimed the wartime dividends were "outlawed." A little more research would have shown that state policies toward dividends were less revolutionary than the chapter supposes. To be sure, a 1938 law controlled dividends, but it hardly eliminated them. A firm that planned to pay more than a 10 percent dividend needed to obtain a permit from the Ministry of Finance (Okazaki 1994, p. 364). Moreover, concludes Johnson (1982) in his well-researched study, "dividends on equity shares continued to be paid until virtually the end of the Pacific War," and "these zaibatsu ownership rights turned out to be virtually the only civilian rights that were respected throughout the wartime period" (p. 139).

Indeed, it is difficult to square the wartime regime's maintenance of the zaibatsu's rights of private ownership with the chapter's insistence that the Japanese state's controls should be considered in the same category as Soviet central planning. Admittedly, wartime bureaucrats and economists studied Soviet planning. It is also true that the government's Planning Board (Kikakuin) included some relatively socialistic bureaucrats, and many wartime planners disliked the zaibatsu for their allegedly selfish, patriotic behavior. However, wartime planners were much more taken by their extensive surveys of Nazi German controls (and, to a lesser extent, the Italian Fascist and even New Deal models). If one looks at the actual policies adopted vis-à-vis capital and labor, they more closely resembled Nazi policies than Soviet programs. This is hardly surprising. Like the Japanese officials, the Nazis denigrated shareholders in favor of workers and managers, yet maintained private ownership by big business. The German corporation law of 1937 likewise permitted the payment of dividends, while diminishing governance by shareholders and reinvesting more of the profits in the companies. Japanese bureaucrats, of course, enjoyed greater access to information on the policies of its German ally than it did to the hostile Soviet Union. As for the influence of the Socialist-leaning experts, many were arrested or removed in 1941 as the result of pressure from big business (Johnson 1982, chap. 4). ${ }^{1}$ In short, the zaibatsu in wartime should not be likened to their Russian counterparts who were obliterated under Soviet rule. They remind us more of Nazi-era big business, which some

1. On the importance of German and fascist models, see Garon (1987), chapter 6, and Fletcher (1982). 
have compared to "the conductor of a runaway bus who has no control over the actions of the driver but keeps collecting the passengers' fares right up to the final crash" (Grunberger 1971, p. 184; see also p. 177).

Moreover, the authors misjudge the nature of the wartime state and pay scant attention to the "transwar" role of the civilian bureaucracy in economic policy. They subscribe to the dated view that the "military assumed dictatorial powers over the economy." Accordingly, they miss what the mainstream scholarship on the Japanese political economy has highlighted for the past two decades: the enormous wartime influence of the "economic bureaucrats" located in the Ministry of Commerce and Industry and its successors. ${ }^{2}$ It was these officials, not military men, who devised the industrial policies that promoted the development of heavy and chemical industries, placed small firms under the control of the zaibatsu, and weakened shareholder control in favor of the managers. These bureaucrats were also forced to conclude that they could not fully subordinate the zaibatsu to state control. The result was not the reduction of the zaibatsu to "serfdom," but rather the evolution of cooperative relationships between the bureaucrats and big business that continued after 1945. Significantly, the economic bureaucrats generally escaped the U.S. occupation's purges and actually saw their authority over the economy strengthened as the Americans supported the continuation of state intervention to revive the economy. The economic bureaucrats gained a powerful base with the formation of the Ministry of International Trade and Industry (MITI) in 1949.

The inclusion of the economic bureaucrats would have nuanced the authors' interesting analysis of the emergence of the postwar keiretsu. As it stands, their chapter explains the rise of keiretsu primarily in terms of the companies' joint defense against corporate raiders in 1952-53. In so doing, however, they ignore the formidable role of the state in the immediate postwar years. They particularly overlook transwar continuities in the thinking of the economic bureaucrats, who sought to diminish the influence of the zaibatsu families and the equity market in favor of bank-centered finance and the state's use of the financial system to promote certain types of industrial development. Long before the attempted hostile takeovers of the early 1950s, the economic bureaucrats were already nudging the dissolved zaibatsu companies toward reconsolidating themselves around banks, rather than the old family holding companies (Johnson 1982, pp. 174, 199, 204-6).

Finally, after a detailed, historical examination of corporate governance, the chapter suggests that the prewar zaibatsu and postwar keiretsu "may have retarded macroeconomic growth." This is an intriguing question, yet there is little in the present essay that rigorously and historically relates cor- 
porate governance to overall growth. Curiously, the authors chose not to critique (or even cite) Chalmers Johnson's influential history of Japanese industrial policy, which placed the zaibatsu and keiretsu at the center of Japan's economic growth before 1975.

\section{References}

Bisson, T. A. 1954. Zaibatsu dissolution in Japan. Berkeley: University of California Press.

Fletcher, William Miles III. 1982. The search for a new order: Intellectuals and fascism in prewar Japan. Chapel Hill: University of North Carolina Press.

Garon, Sheldon. 1987. State and labor in modern Japan. Berkeley: University of California Press.

Garon, Sheldon, and Mike Mochizuki. 1993. Negotiating social contracts. In Postwar Japan as history, ed. Andrew Gordon, 145-66. Berkeley: University of California Press.

Grunberger, Richard. 1971. The 12-year reich: A social history of Nazi Germany, 1933-1945. New York: Holt, Reinhart.

Johnson, Chalmers. 1982. MITI and the Japanese miracle: The growth of industrial policy, 1925-1975. Stanford, CA: Stanford University Press.

Noguchi, Yukio. 1995. 1940 nen taisei [1940 system]. Tokyo: Toyo keizai shinposha.

Okazaki, Tetsuji. 1994. The Japanese firm under the wartime planned economy. In The Japanese firm, ed. Masahiko Aoki and Ronald Dore, 350-77. Oxford: Oxford University Press.

Samuels, Richard J. 2003. Machiavelli's children: Leaders and their legacies in Italy and Japan. Ithaca, NY: Cornell University Press. 
